Cochrane Database of Systematic Reviews

\title{
Nebulised hypertonic saline solution for acute bronchiolitis in infants (Review)
}

Zhang L, Mendoza-Sassi RA, Wainwright C, Klassen TP

Zhang L, Mendoza-Sassi RA, Wainwright C, Klassen TP.

Nebulised hypertonic saline solution for acute bronchiolitis in infants.

Cochrane Database of Systematic Reviews 2017, Issue 12. Art. No.: CD006458.

DOI: 10.1002/14651858.CD006458.pub4.

www.cochranelibrary.com 
TABLE OF CONTENTS

HEADER 1

ABSTRACT

PLAIN LANGUAGE SUMMARY

SUMMARY OF FINDINGS

BACKGROUND

OBJECTIVES

METHODS

Figure 1.

RESULTS

Figure 2.

Figure 3.

DISCUSSION

AUTHORS' CONCLUSIONS

ACKNOWLEDGEMENTS

REFERENCES

CHARACTERISTICS OF STUDIES

DATA AND ANALYSES

Analysis 1.1. Comparison 1 Hypertonic saline versus normal saline (0.9\%), Outcome 1 Length of hospital stay (days).

Analysis 1.2. Comparison 1 Hypertonic saline versus normal saline (0.9\%), Outcome 2 Rate of hospitalisation.

Analysis 1.3. Comparison 1 Hypertonic saline versus normal saline (0.9\%), Outcome 3 Clinical severity score (post-treatment) at day 1 .

Analysis 1.4. Comparison 1 Hypertonic saline versus normal saline (0.9\%), Outcome 4 Clinical severity score (post-treatment) at day 2 .

Analysis 1.5. Comparison 1 Hypertonic saline versus normal saline (0.9\%), Outcome 5 Clinical severity score (post-treatment) at day 3.

Analysis 1.6. Comparison 1 Hypertonic saline versus normal saline (0.9\%), Outcome 6 Rate of re-admission.

Analysis 1.7. Comparison 1 Hypertonic saline versus normal saline (0.9\%), Outcome 7 Time for resolution of symptoms/signs. .

Analysis 1.8. Comparison 1 Hypertonic saline versus normal saline (0.9\%), Outcome 8 Radiological assessment score. ADDITIONAL TABLES

APPENDICES

WHAT'S NEW

HISTORY

CONTRIBUTIONS OF AUTHORS

DECLARATIONS OF INTEREST

SOURCES OF SUPPORT

DIFFERENCES BETWEEN PROTOCOL AND REVIEW

INDEX TERMS 
[Intervention Review]

\section{Nebulised hypertonic saline solution for acute bronchiolitis in infants}

Linjie Zhang ${ }^{1}$, Raúl A Mendoza-Sassi ${ }^{1}$, Claire Wainwright ${ }^{2}$, Terry P Klassen ${ }^{3}$

1Faculty of Medicine, Federal University of Rio Grande, Rio Grande, Brazil. 2Department of Respiratory Medicine, Royal Children's

Hospital, Brisbane, Australia. ${ }^{3}$ Manitoba Institute of Child Health, Winnipeg, Canada

Contact address: Linjie Zhang, Faculty of Medicine, Federal University of Rio Grande, Rua Visconde Paranaguá 102, Centro, Rio Grande, RS, 96201-900, Brazil. lzhang@furg.br.

Editorial group: Cochrane Acute Respiratory Infections Group.

Publication status and date: New search for studies and content updated (conclusions changed), published in Issue 12, 2017.

Citation: Zhang L, Mendoza-Sassi RA, Wainwright C, Klassen TP. Nebulised hypertonic saline solution for acute bronchiolitis in infants. Cochrane Database of Systematic Reviews 2017, Issue 12. Art. No.: CD006458. DOI: 10.1002/14651858.CD006458.pub4.

Copyright @ 2017 The Cochrane Collaboration. Published by John Wiley \& Sons, Ltd.

\section{A B S T R A C T}

\section{Background}

Airway oedema (swelling) and mucus plugging are the principal pathological features in infants with acute viral bronchiolitis. Nebulised hypertonic saline solution $(\geq 3 \%)$ may reduce these pathological changes and decrease airway obstruction. This is an update of a review first published in 2008, and previously updated in 2010 and 2013.

\section{Objectives}

To assess the effects of nebulised hypertonic ( $\geq 3 \%)$ saline solution in infants with acute bronchiolitis.

\section{Search methods}

We searched the Cochrane Central Register of Controlled Trials (CENTRAL), MEDLINE, MEDLINE Epub Ahead of Print, In-Process \& Other Non-Indexed Citations, Ovid MEDLINE Daily, Embase, CINAHL, LILACS, and Web of Science on 11 August 2017. We also searched the World Health Organization International Clinical Trials Registry Platform (WHO ICTRP) and ClinicalTrials.gov on 8 April 2017.

\section{Selection criteria}

We included randomised controlled trials and quasi-randomised controlled trials using nebulised hypertonic saline alone or in conjunction with bronchodilators as an active intervention and nebulised $0.9 \%$ saline, or standard treatment as a comparator in children under 24 months with acute bronchiolitis. The primary outcome for inpatient trials was length of hospital stay, and the primary outcome for outpatients or emergency department trials was rate of hospitalisation.

\section{Data collection and analysis}

Two review authors independently performed study selection, data extraction, and assessment of risk of bias in included studies. We conducted random-effects model meta-analyses using Review Manager 5. We used mean difference (MD), risk ratio (RR), and their 95\% confidence intervals $(\mathrm{Cl})$ as effect size metrics.

\section{Main results}

We identified 26 new trials in this update, of which 9 await classification due to insufficient data for eligibility assessment, and 17 trials $(\mathrm{N}=3105)$ met the inclusion criteria. We included a total of 28 trials involving 4195 infants with acute bronchiolitis, of whom 2222 infants received hypertonic saline.

Hospitalised infants treated with nebulised hypertonic saline had a statistically significant shorter mean length of hospital stay compared to those treated with nebulised $0.9 \%$ saline (MD -0.41 days, $95 \% \mathrm{Cl}-0.75$ to $-0.07 ; \mathrm{P}=0.02, \mathrm{I}^{2}=79 \% ; 17$ trials; 1867 infants) (GRADE quality of evidence: low). Infants who received hypertonic saline also had statistically significant lower post-inhalation clinical scores than infants 
who received $0.9 \%$ saline in the first three days of treatment (day $1: \mathrm{MD}-0.77,95 \% \mathrm{Cl}-1.18$ to $-0.36, \mathrm{P}<0.001 ;$ day $2: \mathrm{MD}-1.28,95 \% \mathrm{Cl}-1.91$ to $-0.65, \mathrm{P}<0.001$; day 3: MD $-1.43,95 \% \mathrm{Cl}-1.82$ to $-1.04, \mathrm{P}<0.001)$ (GRADE quality of evidence: low).

Nebulised hypertonic saline reduced the risk of hospitalisation by $14 \%$ compared with nebulised $0.9 \%$ saline among infants who were outpatients and those treated in the emergency department (RR $0.86,95 \% \mathrm{Cl} 0.76$ to $0.98 ; \mathrm{P}=0.02, \mathrm{I}^{2}=7 \% ; 8$ trials; 1723 infants) (GRADE quality of evidence: moderate).

Twenty-four trials presented safety data: 13 trials (1363 infants, 703 treated with hypertonic saline) did not report any adverse events, and 11 trials (2360 infants, 1265 treated with hypertonic saline) reported at least one adverse event, most of which were mild and resolved spontaneously.

\section{Authors' conclusions}

Nebulised hypertonic saline may modestly reduce length of stay among infants hospitalised with acute bronchiolitis and improve clinical severity score. Treatment with nebulised hypertonic saline may also reduce the risk of hospitalisation among outpatients and emergency department patients. However, we assessed the quality of the evidence as low to moderate.

\section{PLAIN LANGUAGE SUMMARY}

\section{Is hypertonic saline solution via nebuliser effective and safe for infants with acute bronchiolitis?}

\section{Review question}

Is hypertonic saline solution via nebuliser effective and safe for the treatment of infants with acute bronchiolitis, compared to normal saline solution?

\section{Background}

Acute bronchiolitis is the most common lower respiratory tract infection in children aged up to two years. Bronchiolitis occurs when small structures (bronchioles) leading to the lungs become infected, causing inflammation, swelling, and mucus production. This makes breathing difficult, especially in very young children, who develop coughs and wheezing.

Because bronchiolitis is usually caused by a virus, drug treatment is usually not effective. Hypertonic saline (sterile salt water solution) breathed in as a fine mist using a nebuliser may help relieve wheezing and breathing difficulty.

We compared nebulised hypertonic $(\geq 3 \%)$ saline solution with nebulised normal $(0.9 \%)$ saline for infants with acute bronchiolitis.

This is an update of a review previously published in 2008, 2010, and 2013.

\section{Search date}

11 August 2017

\section{Study characteristics}

We identified 26 new studies in this update, of which 9 await assessment and 17 trials $(\mathrm{N}=3105)$ were added. We included a total of 28 trials involving 4195 infants with acute bronchiolitis.

\section{Key results}

Nebulised hypertonic saline may reduce hospital stay by 10 hours in comparison to normal saline for infants admitted with acute bronchiolitis. We found that 'clinical severity scores', which are used by doctors to assess patient health, for children treated as outpatients or in hospital improved when administered nebulised hypertonic saline compared to normal saline. Nebulised hypertonic saline may also reduce the risk of hospitalisation by $14 \%$ among children treated as outpatients or in the emergency department. We found only minor and spontaneously resolved adverse effects from the use of nebulised hypertonic saline when given with treatment to relax airways (bronchodilators).

Reductions in hospital stay were smaller than previously thought. However, an average reduction of 10 hours in the length of hospital stay for infants is significant because bronchiolitis usually has a short duration. Nebulised hypertonic saline appears to be safe and widely available at low cost.

\section{Quality of evidence}

The quality of the evidence was low to moderate: there were inconsistencies in results among trials and risk of bias in some trials. Future large trials are therefore needed to confirm the benefits of nebulised hypertonic saline for children with bronchiolitis treated as outpatients and in hospital. 


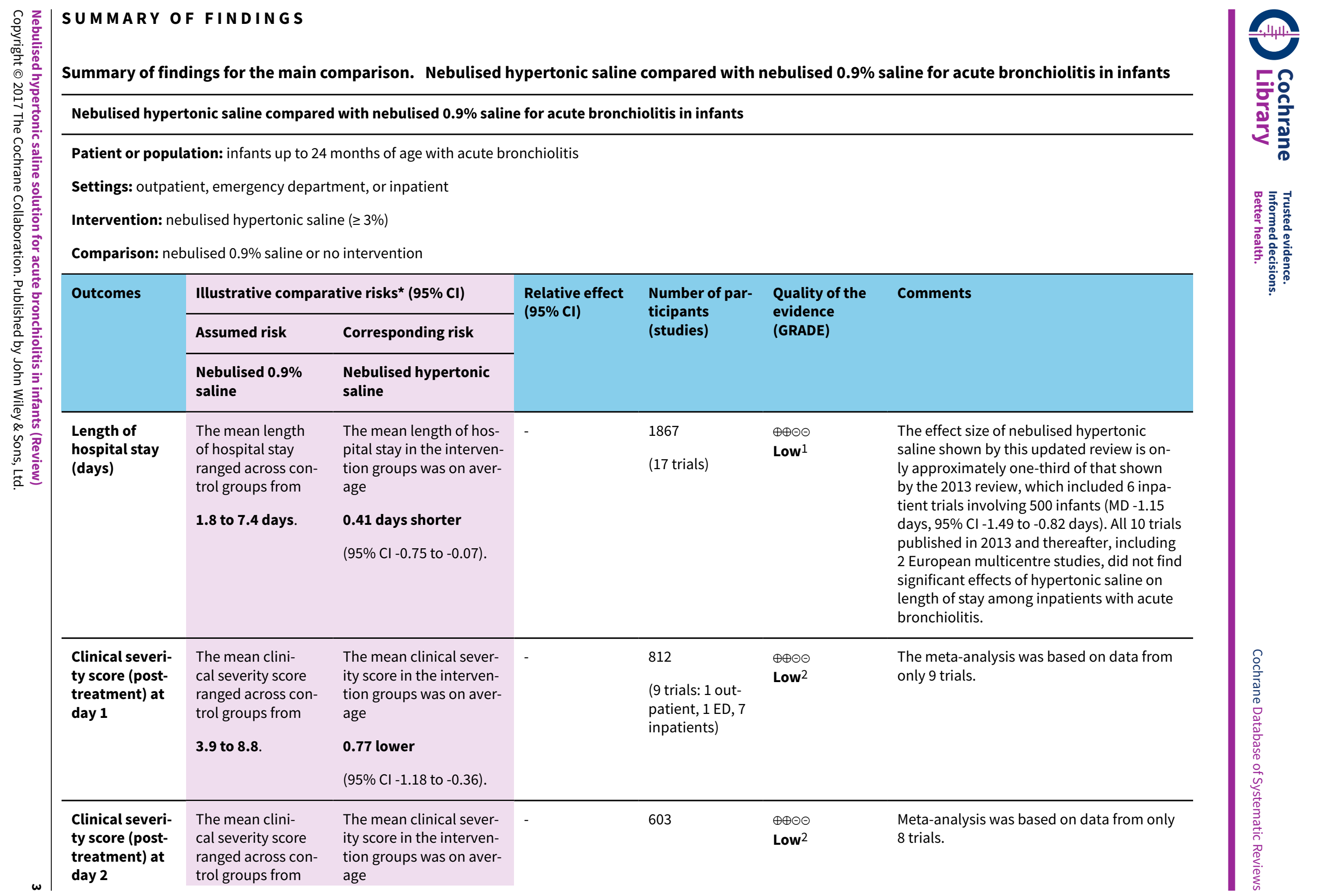




\begin{tabular}{|c|c|c|c|c|c|c|}
\hline \multirow[b]{2}{*}{$\begin{array}{l}\text { Clinical severi- } \\
\text { ty score (post- } \\
\text { treatment) at } \\
\text { day } 3\end{array}$} & 3.8 to 8.2 . & $\begin{array}{l}1.28 \text { lower } \\
\text { (95\% Cl -1.91 to }-0.65) \text {. }\end{array}$ & & \multicolumn{2}{|l|}{$\begin{array}{l}\text { ( } 8 \text { trials: } 1 \text { out- } \\
\text { patient, } 1 \mathrm{ED}, 6 \\
\text { inpatient) }\end{array}$} & \multirow[b]{2}{*}{$\begin{array}{l}\text { Meta-analysis was based on data from only } \\
7 \text { trials. }\end{array}$} \\
\hline & $\begin{array}{l}\text { The mean clini- } \\
\text { cal severity score } \\
\text { ranged across con- } \\
\text { trol groups from } \\
\mathbf{1 . 9} \text { to } \mathbf{7 . 6}\end{array}$ & $\begin{array}{l}\text { The mean clinical sever- } \\
\text { ity score in the interven- } \\
\text { tion groups was on aver- } \\
\text { age } \\
\mathbf{1 . 4 3} \text { lower } \\
\text { (95\% Cl-1.82 to -1.04). }\end{array}$ & - & $\begin{array}{l}499 \\
\text { (7 trials: } 1 \text { out- } \\
\text { patient, } 6 \text { inpa- } \\
\text { tient) }\end{array}$ & $\begin{array}{l}\oplus \oplus \odot \odot \\
\text { Low }^{2}\end{array}$ & \\
\hline $\begin{array}{l}\text { Hospitalisa- } \\
\text { tion rate }\end{array}$ & 42 per 100 & 35 per 100 & $\begin{array}{l}\text { RR } 0.86 \\
(0.76 \text { to } 0.98)\end{array}$ & $\begin{array}{l}1723 \\
\text { (8 trials: } 1 \text { out- } \\
\text { patient, } 7 \mathrm{ED} \text { ) }\end{array}$ & $\begin{array}{l}\oplus \oplus \oplus \ominus \\
\text { Moderate }^{3}\end{array}$ & \\
\hline $\begin{array}{l}\text { Re-admission } \\
\text { rate }\end{array}$ & 15 per 100 & 12 per 100 & $\begin{array}{l}\text { RR } 0.77 \\
(0.48 \text { to } 1.25)\end{array}$ & $\begin{array}{l}787 \\
\text { (6 trials: } 1 \text { inpa- } \\
\text { tient, } 5 \text { ED) }\end{array}$ & $\begin{array}{l}\oplus \oplus \oplus \ominus \\
\text { Moderate }^{4}\end{array}$ & $\begin{array}{l}\text { Meta-analysis was based on data from only } \\
6 \text { trials }\end{array}$ \\
\hline Adverse events & See comment & See comment & Not estimable & $\begin{array}{l}3723 \text { (1968 re- } \\
\text { ceived hyper- } \\
\text { tonic saline) } \\
\text { (24 trials) }\end{array}$ & Not applicable & $\begin{array}{l}13 \text { trials ( } 1363 \text { infants, } 703 \text { treated with hy- } \\
\text { pertonic saline) did not report any adverse } \\
\text { events, and } 11 \text { trials ( } 2360 \text { infants, } 1265 \\
\text { treated with hypertonic saline) reported at } \\
\text { least } 1 \text { adverse event; most adverse events } \\
\text { were mild and resolved spontaneously. }\end{array}$ \\
\hline
\end{tabular}

*The basis for the assumed risk (e.g. the median control group risk across studies) is provided in footnotes. The corresponding risk (and its $95 \%$ confidence interval) is based on the assumed risk in the comparison group and the relative effect of the intervention (and its $95 \% \mathrm{Cl}$ ).

Cl: confidence interval; ED: emergency department; MD: mean difference; RR: risk ratio

GRADE Working Group grades of evidence ( 5 domains: limitations in design, inconsistency, indirectness, imprecision, reporting bias)

High quality: Further research is very unlikely to change our confidence in the estimate of effect.

Moderate quality: Further research is likely to have an important impact on our confidence in the estimate of effect and may change the estimate.

Low quality: Further research is very likely to have an important impact on our confidence in the estimate of effect and is likely to change the estimate.

Very low quality: We are very uncertain about the estimate.

The assumed risk was based on data from the included trials.

${ }^{1}$ We downgraded the quality of the evidence to low due to inconsistent results between studies (high heterogeneity) and risk of bias.

2 We downgraded the quality of the evidence to low due to inconsistent results between studies (high heterogeneity) and risk of bias.

3 We downgraded the quality of the evidence to moderate due to high clinical heterogeneity between studies.

4 We downgraded the quality of the evidence to moderate because the meta-analysis was based on data from a small part of the included trials. 


\section{B A C K G R O U N D}

\section{Description of the condition}

Acute bronchiolitis is the most frequent lower respiratory tract infection in infants (Klassen 1997a), and the most common causative organism is respiratory syncytial virus (RSV). Other less common pathogens include parainfluenza viruses, adenovirus, influenza A and B, rhinovirus, human metapneumovirus and Mycoplasma pneumoniae (García-García 2006; Henderson 1979; Jacques 2006; Rose 1987; Shay 2001). Virtually all infants are infected by RSV by the age of two years, around $40 \%$ to $50 \%$ develop involvement of the lower respiratory tract, and $1 \%$ to $2 \%$ develop severe disease leading to hospitalisation (Meissner 2003; Rakshi 1994; Shay 1999). It is estimated that globally in 2015, 1.4 million (uncertainty range (UR) 1.2 to 1.7) hospital admissions, and 27,300 (UR 20700 to 36200) in-hospital deaths were due to RSV-acute lower respiratory infection in infants younger than six months of age (Shi 2017).

The principal pathological findings in acute bronchiolitis include a peribronchial infiltrate of inflammatory cells, mucosal and submucosal oedema, necrosis and desquamation of ciliated epithelial cells, proliferation of cuboidal cells, and excess mucus secretion (Panitch 1993; Wohl 1978). The combination of airway wall swelling, sloughing of necrotic debris, increased mucus production, and impaired secretion clearance eventually leads to airway obstruction, gas trapping, atelectasis, and impaired gas exchange.

The diagnosis of acute bronchiolitis is usually based on clinical grounds. Despite differences in defining bronchiolitis, it is generally accepted that acute bronchiolitis refers to the first episode of acute wheezing in children aged less than two years, starting as a viral upper respiratory infection (coryza, cough, or fever) (Panitch 1993). These criteria for diagnosis of acute bronchiolitis have also been widely used in clinical trials (Bertrand 2001; Klassen 1997b; Schuh 1992; Wainwright 2003; Zhang 2003). Direct fluorescent antibody tests, enzyme immuno-assay techniques, and cultures of the nasopharyngeal aspirate may be used to identify the causative pathogen

\section{Description of the intervention}

The standard treatment for acute bronchiolitis remains supportive care and includes ensuring adequate oxygen exchange, fluid intake, and feeding of the infant (Panitch 2003; Wohl 2003). Convincing evidence for any other therapy is lacking. Because airway oedema and mucus plugging are the predominant pathological features in acute bronchiolitis, any therapy that can reduce these changes and improve the clearance of airway secretions may be beneficial.

Epinephrine has a theoretical effect on acute bronchiolitis because it contains alpha adrenergic properties which lead to vasoconstriction and reduction of airway oedema (Wohl 1978). However, a Cochrane Review showed that nebulised epinephrine for acute bronchiolitis results in a modest short-term improvement in outpatients, but not among inpatients (Hartling 2011). Inhaled recombinant deoxyribonuclease (rhDNase), a mucolytic agent, has also been tested in hospitalised infants with acute bronchiolitis (Nasr 2001). This drug is thought to exert its major effect by enhancing airway secretion clearance. However, no significant effect was observed on clinical severity scores or length of hospital stay (Enriquez 2012). Another widely used approach is chest physiotherapy, which is thought to assist infants by enhancing the clearance of secretions and reducing ventilatory effort. However, current evidence has shown that chest physiotherapy (vibration and percussion or passive expiratory techniques) does not reduce the length of hospital stay or oxygen requirements or improve the severity of the disease respiratory parameters in hospitalised infants with acute bronchiolitis (Roqué i Figuls 2016).

Hypertonic saline has been used as a treatment for infants with acute bronchiolitis. Most randomised trials demonstrate that nebulised 3\% saline may significantly reduce the length of hospital stay and improve the clinical severity score in infants with acute viral bronchiolitis (Luo 2010; Mandelberg 2003; Sarrell 2002; Tal 2006).

\section{How the intervention might work}

Hypertonic saline solution has been shown to increase mucociliary clearance in disease-free people and people with asthma, bronchiectasis, cystic fibrosis, and sinonasal diseases (Daviskas 1996; Kellett 2005; Shoseyov 1998; Wark 2009). Such benefits would also be expected in infants with acute bronchiolitis (Mandelberg 2010). The postulated mechanisms of benefit of hypertonic saline are:

- induces an osmotic flow of water into the mucus layer, rehydrating the airway surface liquid and improving mucus clearance (Mandelberg 2010; Robinson 1997);

- breaks the ionic bonds within the mucus gel, thereby reducing the degree of cross-linking and entanglements and lowering the viscosity and elasticity of the mucus secretion (Ziment 1978);

- stimulates cilial beat via the release of prostaglandin E2 (Assouline 1977).

Moreover, by absorbing water from the mucosa and submucosa, hypertonic saline solution can theoretically reduce oedema of the airway wall in infants with acute bronchiolitis (Mandelberg 2003; Mandelberg 2010; Sarrell 2002). Hypertonic saline inhalation can also cause sputum induction and cough, which can help to clear the sputum outside of the bronchi and thus improve airway obstruction (Mandelberg 2003).

These theoretical benefits provide the rationale for the treatment of acute bronchiolitis with nebulised hypertonic saline solution.

\section{Why it is important to do this review}

The hypothesis of this review is that nebulised hypertonic saline solution is beneficial in the management of acute bronchiolitis as assessed by clinically relevant outcomes, both in inpatients and outpatients. The establishment of a therapeutic role for hypertonic saline solution in acute bronchiolitis has relevant clinical implications. This modality may provide a cheap and effective therapy for children with acute bronchiolitis.

\section{O B JECTIVES}

To assess the effects of nebulised hypertonic ( $\geq 3 \%$ ) saline solution in infants with acute bronchiolitis. 


\section{METHODS}

\section{Criteria for considering studies for this review \\ Types of studies}

We included randomised controlled trials and quasi-randomised controlled trials (in which there is alternate allocation to treatment and control groups) in this review. We excluded studies including participants who had recurrent wheezing or who were intubated and ventilated, and studies that assessed pulmonary function alone.

\section{Types of participants}

Children up to 24 months of age diagnosed with acute bronchiolitis. Acute bronchiolitis was defined as the first episode of acute wheezing associated with clinical evidence of a viral infection (cough, coryza, or fever). Confirmation of viral aetiology was not necessary for study inclusion. We included studies of inpatients, emergency department patients, or outpatients.

\section{Types of interventions}

- Nebulised hypertonic saline alone versus nebulised $0.9 \%$ saline.

- Nebulised hypertonic saline plus bronchodilator versus nebulised $0.9 \%$ saline.

- Nebulised hypertonic saline plus bronchodilator versus nebulised $0.9 \%$ saline plus same bronchodilator.

- Nebulised hypertonic saline alone or plus bronchodilator versus standard treatment.

Given that we identified few studies initially in 2007, we subsequently added comparisons of nebulised hypertonic saline alone versus nebulised $0.9 \%$ saline or no intervention (Zhang 2008). Hypertonic saline was defined as a concentration of saline greater than or equal to $3 \%$.

\section{Types of outcome measures}

\section{Primary outcomes}

1. Length of hospital stay or time taken to be ready for discharge (inpatients).

2. Rate of hospitalisation (outpatients or emergency department patients).

\section{Secondary outcomes}

1. Clinical severity score.

2. Rate of re-admission to hospital.

3. Haemoglobin saturation (oximetry).

4. Respiratory rate.

5. Heart rate.

6. Time to resolution of symptoms or signs.

7. Duration of in-hospital oxygen supplementation.

8. Need for add-on treatment (bronchodilator, systemic corticosteroids, antibiotics, and oxygen supplementation).
9. Results of pulmonary function tests.

10. Radiological findings.

11.Adverse events (tachycardia, hypertension, pallor, tremor, nausea, vomiting, diarrhoea, and acute urinary retention).

\section{Search methods for identification of studies}

\section{Electronic searches}

We searched the Cochrane Central Register of Controlled Trials (CENTRAL; 2016, Issue 4), part of the Cochrane Library (searched 11 August 2017), which contains the Cochrane Acute Respiratory Infections Group Specialised Register, MEDLINE Ovid, MEDLINE Epub Ahead of Print, In-Process \& Other Non-Indexed Citations, Ovid MEDLINE Daily (April 2013 to 11 August 2017), Embase.com (April 2013 to 11 August 2017), CINAHL (Cumulative Index to Nursing and Allied Health Literature) (EBSCO; May 2013 to 11 August 2017), LILACS (Latin American and Caribbean Health Science Information Database) (May 2013 to 11 August 2017), and Web of Science (May 2013 to 11 August 2017) for this update. Appendix 1 provides details of searches conducted for previous versions of this review.

We used the search strategy in Appendix 2 to search MEDLINE and CENTRAL. Because there were so few search results, we used no filter to identify randomised trials in MEDLINE. We adapted the terms to search Embase (Appendix 3), LILACS (Appendix 4), CINAHL (Appendix 5), and Web of Science (Appendix 6).

\section{Searching other resources}

We searched the World Health Organization International Clinical Trials Registery Platform (WHO ICTRP) and US National Institutes of Health Ongoing Trials Register ClinicalTrials.gov to identify ongoing trials on 8 April 2017. We checked reference lists of all primary studies and review articles for additional relevant trials.

\section{Data collection and analysis}

We conducted the review update according to the published protocol and reported any deviations from it in the Differences between protocol and review section.

\section{Selection of studies}

Two review authors (LZ, RAM) independently screened titles and abstracts of all studies identified as a result of the search for potential inclusion in the review. We retrieved the full-text study reports of all potentially eligible studies, and two review authors (LZ, RAM) independently screened the full-text reports to identify studies for inclusion and identify and record reasons for exclusion of ineligible studies. Any disagreements were resolved through discussion or, if required, by consulting a third review author (CW). We identified and excluded duplicates and collated multiple reports of the same study so that each study, rather than each report, was the unit of interest in the review. We recorded the selection process in a PRISMA flow diagram (Figure 1) and Characteristics of excluded studies table. There were no language or publication restrictions. 
Figure 1. Study flow diagram.

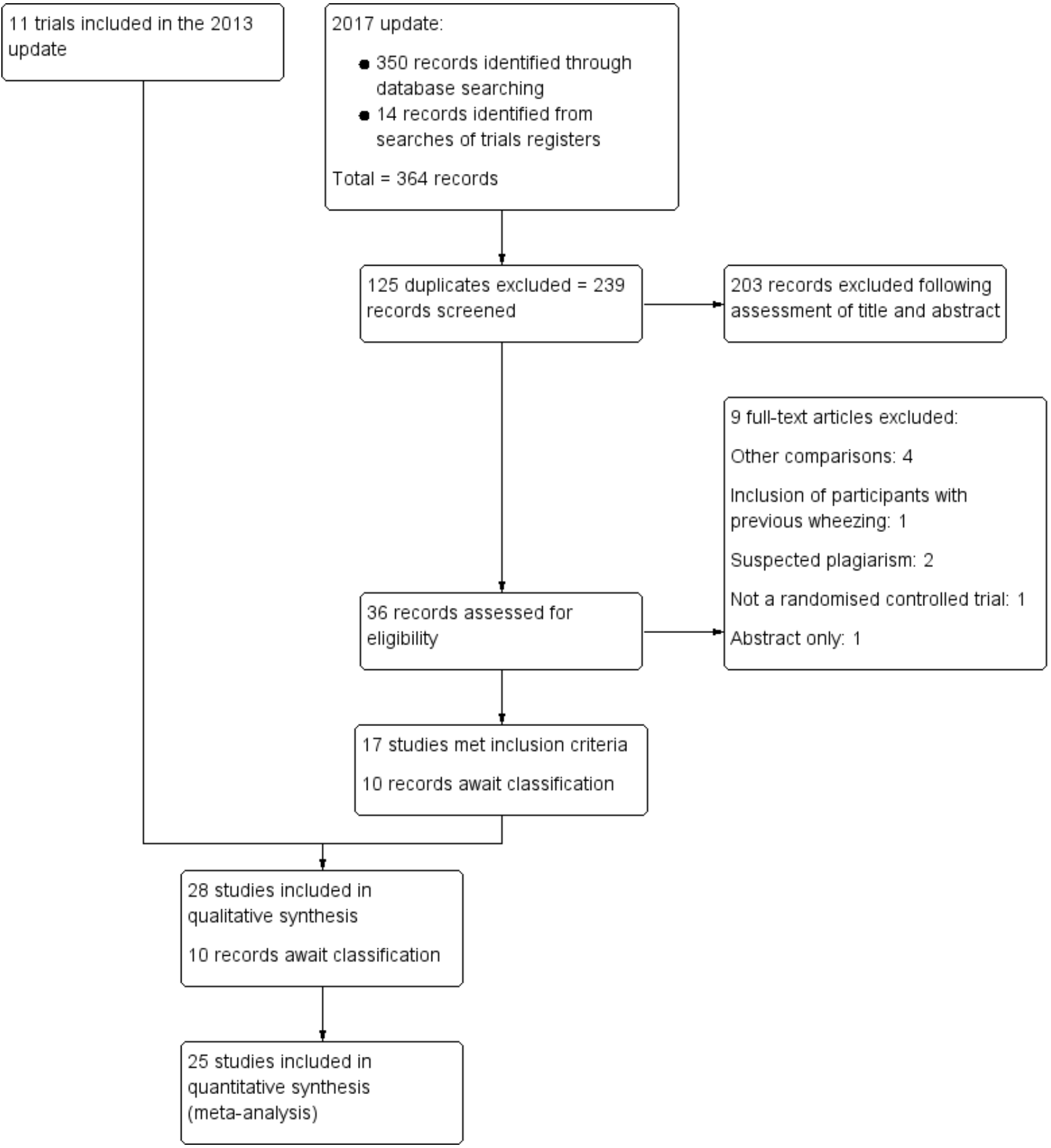

\section{Data extraction and management}

One review author (LZ) extracted study details from the included trials using a standardised data extraction form. Another review author (RAM) checked the data extraction. We resolved any disagreements by discussion. We entered the extracted the following data into Review Manager 5 (RevMan 2014).

1. Methods: study design, total duration of study, details of any 'run in' period, number of study centres and location, study setting, withdrawals, and date of study.
2. Participants: N, mean age, age range, gender, severity of condition, diagnostic criteria, baseline lung function, smoking history, inclusion criteria, and exclusion criteria.

3. Interventions: intervention, comparison, concomitant medications, and excluded medications.

4. Outcomes: primary and secondary outcomes specified and collected, and time points reported.

5. Notes: funding for trial, and notable conflicts of interest of trial authors. 
We used Engauge digitising software to extract the first and third quartile values of length of hospital stay from a figure in Teunissen 2014. For this trial, we estimated mean and standard deviation from median and interquartile range of length of hospital stay using methods described by Wan 2014.

\section{Assessment of risk of bias in included studies}

Two review authors (LZ, RAM) independently assessed risk of bias for each study using the criteria outlined in the Cochrane Handbook for Systematic Reviews of Interventions (Higgins 2011). Any disagreements were resolved by discussion or by involving a third review author (CW). We assessed risk of bias according to the following domains.

1. Random sequence generation.

2. Allocation concealment.

3. Blinding of participants and personnel.

4. Blinding of outcome assessment.

5. Incomplete outcome data.

6. Selective outcome reporting.

7. Other bias.

We graded each potential source of bias as high, low, or unclear and provided a quote from the study report together with a justification for our judgement in the 'Risk of bias' table. We summarised the 'Risk of bias' judgements across different studies for each of the domains listed. We considered blinding separately for different key outcomes where necessary. Where information on risk of bias related to unpublished data or correspondence with a trialist, this was noted in the 'Risk of bias' table.

When considering treatment effects, we took into account the risk of bias for the studies that contributed to that outcome.

\section{Measures of treatment effect}

We entered outcome data for each study into data tables in Review Manager 5 to calculate the treatment effects (RevMan 2014). We used risk ratio for dichotomous outcomes, and mean differences or standardised mean differences for continuous outcomes.

We conducted meta-analyses only where this was meaningful, that is if treatments, participants, and the underlying clinical question were sufficiently similar for pooling to make sense.

\section{Unit of analysis issues}

The participants in each intervention arm were the unit of analysis in a single parallel group design. When trials recruited multiple groups, we combined data to create hypertonic saline and normal saline groups. We used the Review Manager 5 calculator to combine groups (RevMan 2014). We combined data for the 5\% and 3\% saline groups into the hypertonic saline group for Al-Ansari 2010 and $7 \%$ and $3 \%$ saline groups into the hypertonic saline group for Köse 2016. We combined four groups reported by Anil 2010 (3\% saline mixed with epinephrine, $3 \%$ saline mixed with salbutamol, $0.9 \%$ saline mixed with epinephrine, and $0.9 \%$ saline mixed with salbutamol) and Ipek 2011 (3\% saline plus salbutamol, 3\% saline alone, $0.9 \%$ saline plus salbutamol, and $0.9 \%$ saline alone) into the hypertonic and normal saline groups.

\section{Dealing with missing data}

We planned to contact investigators or study sponsors to verify key study characteristics and to obtain missing numerical outcome data where possible (e.g. when a study was identified as an abstract only). Where this was not possible, and the missing data were thought to introduce serious bias, we explored the impact of including such studies in the overall assessment of results by performing sensitivity analyses.

If numerical outcome data such as standard deviations or correlation coefficients were missing and could not be obtained from the authors, we planned to calculate these from other available statistics such as $P$ values according to the methods described in the Cochrane Handbook for Systematic Reviews of Interventions (Higgins 2011).

We contacted the authors of seven studies for additional trial data (Köse 2016; Kuzik 2007; Luo 2010; Mandelberg 2003; Sharma 2013; Teunissen 2014; Wu 2014), of whom five responded and provided data (Köse 2016; Kuzik 2007; Luo 2010; Mandelberg 2003; Wu 2014).

\section{Assessment of heterogeneity}

We used the $\mathrm{I}^{2}$ statistic to measure heterogeneity among the trials in each analysis. If we identified substantial heterogeneity, we reported this and explored possible causes in subgroup analysis. We used $\mathrm{I}^{2}$ values of $25 \%, 50 \%$, and $75 \%$ corresponding to low, moderate, and high heterogeneity, respectively (Higgins 2003).

\section{Assessment of reporting biases}

If we were able to pool more than 10 trials, we planned to create and examine a funnel plot to explore possible small-study effects and publication bias. We created the funnel plot using Stata version 11.0.

\section{Data synthesis}

We pooled data from studies we judged to be clinically homogeneous using Review Manager 5 software (RevMan 2014). If more than one study provided usable data in any single comparison, we performed meta-analysis using the random-effects model. Whenever possible, we used intention-to-treat analysis data.

\section{GRADE and 'Summary of findings' table}

We created a 'Summary of findings' table using the following outcomes: length of hospital stay; clinical severity score posttreatment at days 1, 2, and 3; rate of hospitalisation; rate of re-admission; and adverse events. We used the five factors of the GRADE approach (study limitations, consistency of effect, imprecision, indirectness, and publication bias) to assess the quality of a body of evidence relating to the studies that contributed data to meta-analyses for outcomes (Atkins 2004). We used methods and recommendations described in Section 8.5 and Chapter 12 of the Cochrane Handbook for Systematic Reviews of Interventions (Higgins 2011), employing GRADEpro GDT software (GRADEpro GDT 2014). We justified all decisions to downor upgrade the quality of studies using footnotes, and made comments to aid readers' understanding of the review where necessary. 


\section{Subgroup analysis and investigation of heterogeneity}

We performed pre-planned subgroup analysis on clinical scores according to patient status (outpatient, emergency department patient, and inpatient). For length of hospital stay, we conducted post hoc subgroup analyses according to availability of virological investigation (available versus not available), upper age limits for participants (12 months versus 18 to 24 months), hypertonic saline concentration ( $3 \%$ versus $>3 \%$ ), administration interval (every 4 to 6 hours versus every 8 hours), co-administration with bronchodilators ( $\beta_{2}$ agonist, epinephrine versus no), length of hospital stay in the control group ( $<3$ days versus $\geq 3$ days), year of publication (before 2013 versus 2013 and thereafter), and risk of selection bias in the trials (low versus unclear/high). For hospitalisation rate, we conducted the same subgroup analyses, except for length of stay in the control group.

We performed post hoc random-effects meta-regression using restricted maximum likelihood (REML) estimation to investigate the potential modifiers of effects of hypertonic saline on length of hospital stay and clinical severity score. We conducted metaregression using Stata version 11.0 (StataCorp 2009).

\section{Sensitivity analysis}

For length of hospital stay, we performed post hoc sensitivity analyses excluding open trials, trials in which mean and standard deviation were estimated from median and interquartile range, trials with withdrawal rate over $15 \%$, and trials with very short $<<$ two days) or very long (> six days) length of stay in the control group.

\section{RE S U L T S}

\section{Description of studies}

\section{Results of the search}

In this 2017 update, we identified 364 records from searches of databases and trials registers. After de-duplication, we assessed 239 records by title and abstract and excluded 203 that did not meet our inclusion criteria. We obtained 26 full-text reports of studies, and following assessment included 17 new trials involving 3105 participants. These were added to the 11 trials (representing 1090 participants) included in the 2013 update (Zhang 2013). Nine studies identified from searches of trials registers are awaiting classification (see Studies awaiting classification).

This update included 28 trials (4195 participants). See Characteristics of included studies.

\section{Included studies}

All 28 included studies were randomised, parallel-group, controlled trials. All but two trials were double-blinded (NCT01238848; Everard 2014). Four studies were multicentre: a hospital in the United Arab Emirates and two hospitals in Canada in Kuzik 2007; 10 centres in England and Wales in Everard 2014; two centres in the USA in Wu 2014; and 24 centres in France in Angoulvant 2017. Three trials were conducted by the same group of investigators in Israel (Mandelberg 2003; Sarrell 2002; Tal 2006), and two trials were conducted by one group of investigators in China (Luo 2010; Luo 2011). The remaining 23 studies were conducted in Argentina (NCT01238848), Canada (Grewal 2009; Kuzik 2007), China (Li 2014), France (Angoulvant 2017), India (Mahesh Kumar 2013; Pandit 2013; Sharma 2013), Italy (Miraglia Del Giudice 2012), Nepal (Khanal 2015;
Ojha 2014), the Netherlands (Teunissen 2014), Poland (RatajczykPekrul 2016), Portugal (Flores 2016), Qatar (Al-Ansari 2010), Tunisia (Tinsa 2014), Turkey (Anil 2010; Ipek 2011; Köse 2016), the UK (Everard 2014), and the USA (Florin 2014; Jacobs 2014; Wu 2014). See Figure 1.

\section{Participants}

Two trials recruited outpatient participants $(\mathrm{N}=194)$ ( $\mathrm{Li}$ 2014; Sarrell 2002); eight trials recruited emergency department participants ( $\mathrm{N}=1873$ ) (Al-Ansari 2010; Angoulvant 2017; Anil 2010; Florin 2014; Grewal 2009; I pek 2011; Jacobs 2014; Wu 2014); 17 trials recruited inpatients $(\mathrm{N}=2028$ ) (NCT01238848; Everard 2014; Flores 2016; Köse 2016; Kuzik 2007; Luo 2010; Luo 2011; Mahesh Kumar 2013; Mandelberg 2003; Miraglia Del Giudice 2012; Ojha 2014; Pandit 2013; Ratajczyk-Pekrul 2016; Sharma 2013; Tal 2006; Teunissen 2014; Tinsa 2014); and one trial recruited both outpatients and emergency department participants $(\mathrm{N}=100)$ (Khanal 2015). The mean age of participants was from 2.6 to 12.5 months (range: 9 days to 24 months).

Criteria for diagnosis of viral bronchiolitis were clearly defined in all but six trials (NCT01238848; Luo 2010; Mandelberg 2003; Miraglia Del Giudice 2012; Sarrell 2002; Tal 2006).

Virological investigation was reported in 15 trials (Angoulvant 2017; Everard 2014; Flores 2016; Grewal 2009; Jacobs 2014; Kuzik 2007; Luo 2010; Luo 2011; Mandelberg 2003; Miraglia Del Giudice 2012; Ratajczyk-Pekrul 2016; Sarrell 2002; Tal 2006; Teunissen 2014; Wu 2014). The positive rate for respiratory syncytial virus (RSV) varied from $42 \%$ to $88 \%$.

Infants who had previous wheezing episodes were excluded from all 28 trials. Infants hospitalised with severe bronchiolitis (requiring mechanical ventilation or intensive care, or oxygen saturation < $85 \%$ on room air) were excluded from all but two trials (Teunissen 2014; Wu 2014).

\section{Interventions}

The concentration of hypertonic saline was defined as 3\% in all but four trials (Al-Ansari 2010; Jacobs 2014; Köse 2016; Tinsa 2014). Two concentrations were used by Al-Ansari 2010 (3\% and 5\%) and Köse 2016 ( $3 \%$ and 7\%). The concentration of hypertonic saline was defined at 5\% in Tinsa 2014 and 7\% in Jacobs 2014.

Treatment regimens of nebulised hypertonic saline (volume, interval of administration, addition of bronchodilator, and treatment duration) varied across studies, especially in emergency department-based trials (Table 1). Oxygen or compressed airdriven jet nebulisers were used for drug deliveries in all trials but Tal 2006, which used ultrasonic nebulisers.

\section{Outcome measures}

All 17 inpatient trials except Tinsa 2014 used length of hospital stay as the primary outcome measure. Length of hospital stay was defined as time from hospital admission to discharge in all but two trials (Everard 2014; Flores 2016), in which both time until fit for discharge and time until discharge were reported. We used time until fit for discharge as length of hospital stay for Everard 2014 and Flores 2016.

The same clinical severity score was used by 11 inpatient trials as a secondary outcome measure (Flores 2016; Köse 2016; Luo 
2010; Luo 2011; Mahesh Kumar 2013; Mandelberg 2003; Miraglia Del Giudice 2012; Ratajczyk-Pekrul 2016; Sharma 2013; Tal 2006; Tinsa 2014). This clinical score was initially described by Wang 1992, grading respiratory rate, wheezing, retraction, and general condition on a scale from 0 to 3, with a higher score indicating increased severity. Other clinical scoring systems were used by two inpatient trials (Kuzik 2007; Ojha 2014).

For outpatient or emergency department participants, outcome measures used were rate of hospitalisation in Angoulvant 2017, Anil 2010, Florin 2014, Grewal 2009, Ipek 2011, Jacobs 2014, Sarrell 2002, and Wu 2014, and rate of re-admission (Al-Ansari 2010; Anil 2010; Florin 2014; Grewal 2009; Khanal 2015). All outpatient or emergency department trials measured clinical severity score.

Other outcome measures were haemoglobin saturation (oximetry) (Al-Ansari 2010; Anil 2010; Florin 2014; Grewal 2009; Ipek 2011; Khanal 2015; Mandelberg 2003; Pandit 2013; Tinsa 2014), heart rate (Anil 2010; Florin 2014; Ipek 2011; Khanal 2015; Mandelberg 2003; Pandit 2013; Sarrell 2002), respiratory rate (Florin 2014; Ipek 2011; Khanal 2015; Pandit 2013), time to resolution of signs and symptoms (Luo 2010; Luo 2011), and need for add-on treatment (Flores 2016; Ipek 2011; Mahesh Kumar 2013; Mandelberg 2003; Pandit 2013; Teunissen 2014; Wu 2014).

The radiological assessment score initially described by Nasr 2001 was used in two trials (Mandelberg 2003; Sarrell 2002).

Side effects associated with inhaled therapies were reported in all but four trials (Ipek 2011; Mahesh Kumar 2013; Miraglia Del Giudice 2012; Ojha 2014).

\section{Excluded studies}

We excluded nine studies in this update (Al-bahadily 2017; Bagus 2012; Bueno Campaña 2014; Flores-González 2015; Flores-González
2016; Gupta 2016; Malik 2015; Nenna 2014; Silver 2015). Reasons for exclusion were: other comparisons (Bueno Campaña 2014; FloresGonzález 2015; Flores-González 2016; Nenna 2014), inclusion of infants with previous history of wheezing (Silver 2015), not a randomised controlled trial (Al-bahadily 2017), and abstract only (Bagus 2012). Two trials from different groups in India presented almost identical results (Gupta 2016; Malik 2015). We contacted the editors of both journals and the corresponding authors of two papers, but neither editors nor authors provided any explanation or information. We excluded both trials because of suspected plagiarism. These were added to studies excluded from previous versions of this review for a total of 13 excluded studies. Reasons for exclusion of the other four studies were: other comparison (Amirav 2005), abstract only (Guomo 2007), not a randomised controlled trial (Tribastone 2003), and inclusion of infants with previous history of wheezing (Kuzik 2010).

\section{Studies awaiting classification}

We identified nine records that appeared to be potentially eligible for inclusion, but published reports or unpublished data were not available (CTRI/2010/091/003065; EudraCT2009-014758-14; NCT00677729; NCT01777347; NCT01834820; NCT02029040; NCT02045238; NCT02233985; NCT02834819). We will search for published reports or seek unpublished data for assessment to include in a future update. However, if no publication has resulted from studies completed for more than five years, these records will be discarded. See Characteristics of studies awaiting classification table.

\section{Risk of bias in included studies}

Summary assessment of six key domains is described below and presented in the 'Risk of bias' tables (Characteristics of included studies) and 'Risk of bias' graph (Figure 2).

Figure 2. 'Risk of bias' graph: review authors' judgements about each risk of bias item presented as percentages across all included studies.

\section{Random sequence generation (selection bias) \\ Allocation concealment (selection bias) \\ Blinding (performance bias and detection bias)}

Incomplete outcome data (attrition bias)

Selective reporting (reporting bias)

Selective reporting (reporting bias)
Other bias

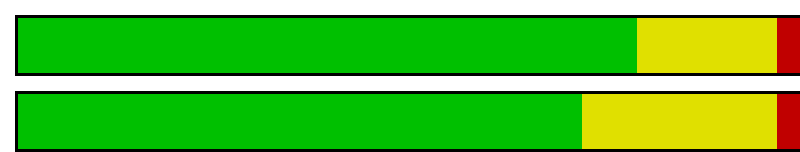

L
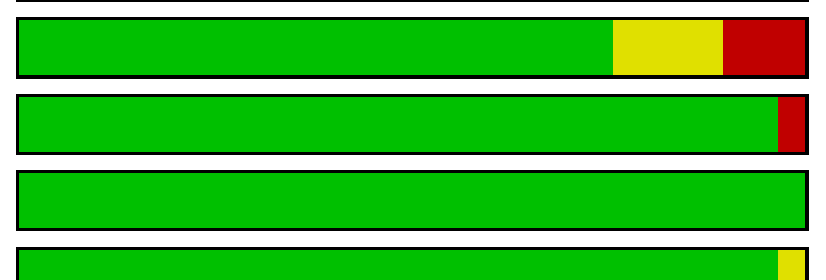

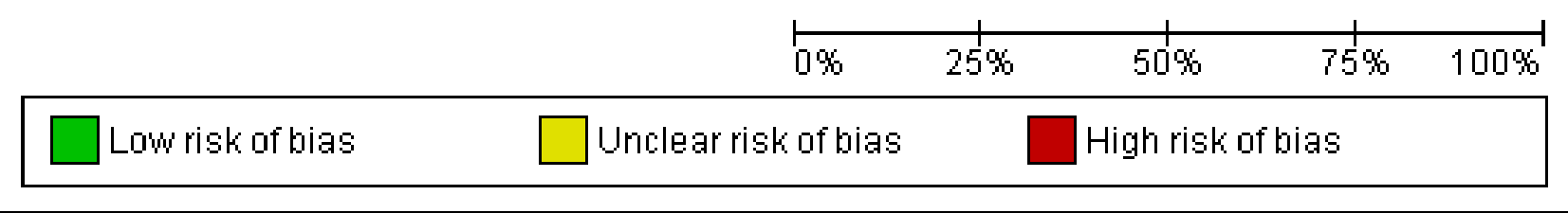

\section{Allocation}

Four trials used an online randomisation tool (Grewal 2009; Mandelberg 2003; Sarrell 2002; Tal 2006); 18 trials used a computer- based random number program (Al-Ansari 2010; Angoulvant 2017; Anil 2010; Everard 2014; Flores 2016; Florin 2014; Khanal 2015; Köse 2016; Kuzik 2007; Luo 2011; Mahesh Kumar 2013; Miraglia 
Del Giudice 2012; Ojha 2014; Pandit 2013; Ratajczyk-Pekrul 2016; Sharma 2013; Tinsa 2014; Wu 2014); and one trial used a random numbers table to generate the random sequence (Li 2014). Two trials used block randomisation (Jacobs 2014; Teunissen 2014), but it was unclear how blocks were chosen at random to create the allocation sequence. Ipek 2011 assigned infants to treatment groups according to the consecutive order of their admission to the emergency department. Three trials did not provide information regarding random sequence generation (NCT01238848; Luo 2010; Mandelberg 2003).

Fourteen trials used sequentially numbered or coded drug containers of identical appearance for allocation concealment (Angoulvant 2017; Anil 2010; Flores 2016; Grewal 2009; Kuzik 2007; Luo 2010; Mandelberg 2003; Ojha 2014; Sarrell 2002; Sharma 2013; Tal 2006; Teunissen 2014; Tinsa 2014; Wu 2014). Six trials used sequentially numbered, sealed envelopes for allocation concealment (Al-Ansari 2010; Florin 2014; Jacobs 2014; Khanal 2015; Luo 2011; Pandit 2013). Everard 2014 used a centralised webbased randomisation system. In Miraglia Del Giudice 2012, study solutions were prepared by the local hospital pharmacy, but the method of allocation concealment was not described. Seven trials did not provide information regarding allocation concealment (Anil 2010; NCT01238848; Ipek 2011; Köse 2016; Li 2014; Mahesh Kumar 2013; Ratajczyk-Pekrul 2016).

\section{Blinding}

In all but seven trials (NCT01238848; Everard 2014; Ipek 2011; Köse 2016; Li 2014; Mahesh Kumar 2013; Pandit 2013), infants, investigators, and care providers were blinded to group assignment. Three trials were open-label (NCT01238848; Everard 2014; Pandit 2013). Another three trials were reported as being double-blinded (Ipek 2011; Köse 2016; Mahesh Kumar 2013), but details were not provided. One trial did not provide information regarding blinding (Li 2014).

\section{Incomplete outcome data}

The number of withdrawals after randomisation was small in all but two trials; the withdrawal rate was $18 \%$ in NCT01238848 and Ojha 2014. The baseline characteristics of participants were similar between treatment groups in all 28 trials. Incomplete outcome data may thus not be a source of bias in this review. Seven trials reported using intention-to-treat analysis (Everard 2014; Florin 2014; Grewal 2009; Kuzik 2007; Mandelberg 2003; Sarrell 2002; Wu 2014).

\section{Selective reporting}

There appeared to be no evidence of selective reporting of outcomes in the included studies. All outcomes proposed in the methods or study protocols were reported in the results. The funnel plots did not suggest small-study effects and publication bias for length of hospital stay among inpatient trials (Figure 3; P $=0.29$ for Egger's test). 
Figure 3. Funnel plot of the weighted mean difference (WMD) of length of hospital stay (days) against its standard error. The circles represent risk estimates of each study, and the black vertical line represents the pooled effect estimate. Dashed lines represent pseudo-95\% confidence limits. Egger test $(P=0.29)$ suggests no small-study effects.

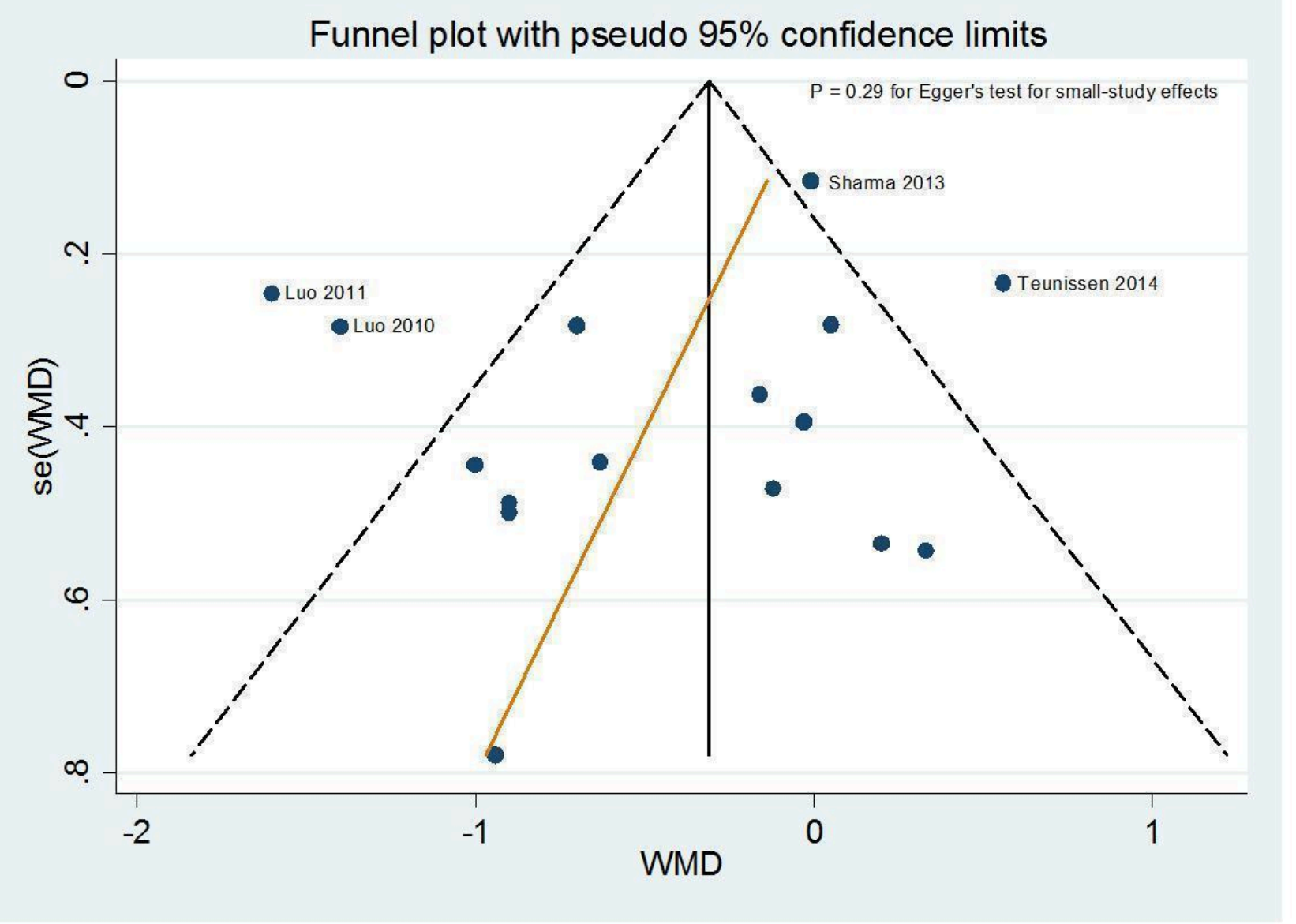

\section{Other potential sources of bias}

We observed no other potential sources of bias in the included trials.

\section{Effects of interventions}

See: Summary of findings for the main comparison Nebulised hypertonic saline compared with nebulised $0.9 \%$ saline for acute bronchiolitis in infants

\section{Primary outcomes}

\section{Length of hospital stay or time taken to be ready for discharge (inpatients)}

All but one of the 17 inpatient trials investigated length of hospital stay as the primary outcome (Tinsa 2014). Tinsa 2014 investigated clinical severity score as the primary outcome and length of stay as the secondary outcome. Two emergency department trials reported the length of stay in infants who required inpatient admission (Angoulvant 2017; Wu 2014). We did not include the data from these two trials in the meta-analysis because inpatients represent only a part of randomised participants. The pooled results of 17 trials with a total of 1867 inpatients showed that infants treated with nebulised hypertonic saline had a statistically significant shorter mean length of hospital stay compared to those treated with nebulised $0.9 \%$ saline (mean difference (MD) of -0.41 days, $95 \%$ confidence interval $(\mathrm{Cl})-0.75$ to -0.07 ; $\mathrm{P}=0.02$; lowquality evidence; Analysis 1.1). There was significant heterogeneity in results among studies $\left(1^{2}=79 \%\right)$.

Table 2 shows the results of seven post hoc subgroup analyses. The effect size of hypertonic saline on length of stay appeared to be greater in subgroups of trials in which virological testing was available, length of stay equal or longer than three days in the control group, use of $3 \%$ hypertonic saline, addition of epinephrine to hypertonic saline solution, and year of publication before 2013. Moderate to high levels of heterogeneity persisted in most subgroup analyses.

The meta-regression analysis did not reveal an independent effect of availability of virological testing, hypertonic saline concentration, co-administration with bronchodilators, length of hospital stay in the control group, and year of publication.

Table 3 shows the results of five post hoc sensitivity analyses. Only one sensitivity analysis excluding two trials, Luo 2010 and Luo 2011, 
with very long (greater than six days) and one trial, Ojha 2014, with very short (less than two days) length of hospital stay in the control group reduced the heterogeneity to a moderate level $\left(\mathrm{I}^{2}\right.$ from $79 \%$ to $50 \%$ ), but the results were no longer statistically significant (MD of -0.22 days, $95 \% \mathrm{Cl}-0.48$ to $0.05 ; \mathrm{P}=0.11$ ).

\section{Rate of hospitalisation (outpatients or emergency department patients)}

Sarrell 2002, an outpatient trial, and seven emergency department trials, Angoulvant 2017, Anil 2010, Florin 2014, Grewal 2009, Ipek 2011, Jacobs 2014, and Wu 2014, ( $N=1723$ ) assessed the efficacy of hypertonic saline in reducing risk of hospitalisation. The pooled risk ratio (RR) was 0.86 ( $95 \% \mathrm{Cl} 0.76$ to $0.98 ; \mathrm{P}=0.02$; moderate-quality evidence; Analysis 1.2). There was no significant heterogeneity among studies $\left(1^{2}=7 \%\right)$

Table 4 shows the results of six post hoc subgroup analyses. The effect size of hypertonic saline on reduction of risk of hospitalisation appeared to be greater in the subgroups of trials in which virological testing was available and multiple doses ( $\geq$ two) of saline solutions were administered.

\section{Secondary outcomes}

\section{Clinical severity scores}

One outpatient trial (Sarrell 2002), one emergency department trial (Al-Ansari 2010), and seven inpatient trials, Flores 2016, Köse 2016, Luo 2010, Luo 2011, Mandelberg 2003, Miraglia Del Giudice 2012, and Tal 2006, compared post-inhalation Wang clinical severity score between infants treated with nebulised hypertonic saline and those treated with nebulised $0.9 \%$ saline on the first three days of treatment. The baseline clinical scores were comparable between groups in all nine trials.

On the first day of treatment, Sarrell 2002 ( $N=65$ outpatients) showed that the $3 \%$ saline group had a statistically significant lower clinical severity score compared to the $0.9 \%$ saline group (MD -1.28 , $95 \% \mathrm{Cl}-1.92$ to $-0.64 ; \mathrm{P}<0.001)$. Seven inpatient trials $(\mathrm{N}=576)$ also demonstrated significant benefits from hypertonic saline in reducing clinical severity score (pooled MD $-0.82,95 \% \mathrm{Cl}-1.25$ to -0.38; $P=0.005 ; I^{2}=67 \%$ ) (Flores 2016; Köse 2016; Luo 2010; Luo 2011; Mandelberg 2003; Miraglia Del Giudice 2012; Tal 2006). In contrast, Al-Ansari 2010 ( $\mathrm{N}=171$ emergency department patients) did not show superiority of hypertonic saline over normal saline in reducing clinical score (MD $-0.09,95 \% \mathrm{Cl}-0.51$ to $0.33 ; \mathrm{P}=0.68$ ). The pooled results of nine trials showed a statistically significant lower clinical severity score favouring treatment with nebulised hypertonic saline over nebulised $0.9 \%$ saline on the first day of treatment (pooled MD $-0.77,95 \% \mathrm{Cl}-1.18$ to -0.36 ; $\mathrm{P}<0.001 ; \mathrm{I}^{2}=$ 74\%; low-quality evidence; Analysis 1.3).

On the second day of treatment, Sarrell 2002 ( $N=65$ outpatients) showed a lower clinical severity score in the $3 \%$ saline group compared to the $0.9 \%$ saline group (MD $-2.0,95 \% \mathrm{Cl}-2.93$ to -1.07 ; $\mathrm{P}<0.001)$. We also observed a statistically significant difference between treatment and control groups among 467 inpatients (pooled MD-1.39, 95\% Cl-1.95 to $-0.84 ; \mathrm{P}<0.001 ;\left.\right|^{2}=76 \%$ ) favouring the 3\% saline group (Flores 2016; Luo 2010; Luo 2011; Mandelberg 2003; Miraglia Del Giudice 2012; Tal 2006). Al-Ansari 2010 (N = 171 emergency department patients) did not demonstrate significant benefits of hypertonic saline in reducing clinical score (MD - 0.27 , $95 \% \mathrm{Cl}-0.63$ to $0.09 ; \mathrm{P}=0.14$ ). Meta-analysis of eight trials demonstrated superiority of nebulised $3 \%$ saline over $0.9 \%$ saline in reducing clinical severity score on the second day of treatment (pooled MD -1.28, 95\% Cl-1.91 to $-0.65 ; \mathrm{P}<0.001 ; \mathrm{I}^{2}=88 \%$; lowquality evidence; Analysis 1.4).

On the third day of treatment, Sarrell 2002 ( $N=65$ outpatients) showed a lower clinical severity score in the 3\% saline group compared to the $0.9 \%$ saline group (MD $-2.64,95 \% \mathrm{Cl}-3.85$ to -1.43 ; $\mathrm{P}<0.001)$. Six inpatient trials $(\mathrm{N}=434)$ also showed a lower clinical severity score in the $3 \%$ saline group (pooled MD $-1.35,95 \% \mathrm{Cl}-1.72$ to $-0.98 ; \mathrm{P}<0.001 ; \mathrm{I}^{2}=57 \%$ ). The pooled results from seven trials demonstrated superiority of nebulised $3 \%$ saline over $0.9 \%$ saline in reducing clinical severity score on the third day of treatment (pooled MD -1.43, 95\% Cl-1.82 to -1.04; $\mathrm{P}<0.001$; $\mathrm{I}^{2}=61 \%$; lowquality evidence; Analysis 1.5).

We performed post hoc meta-regression analysis to explore possible causes of heterogeneity among studies regarding the effect size of hypertonic saline on clinical score during the first three days of treatment. The small number of studies enabled inclusion of only one relevant covariate in the model, which was the severity of bronchiolitis assessed by baseline clinical score in the $0.9 \%$ saline group. The meta-regression analysis yielded a regression coefficient of $-0.11(95 \% \mathrm{Cl}-0.35$ to $0.11 ; \mathrm{P}=0.30)$, suggesting that disease severity did not significantly influence the effect size of hypertonic saline on clinical score.

Eight emergency department-based trials assessed short-term effects (30 minutes to 120 minutes) of up to three doses of nebulised hypertonic saline in improving clinical severity score among infants with acute bronchiolitis (Angoulvant 2017; Anil 2010; Florin 2014; Grewal 2009; Ipek 2011; Jacobs 2014; Khanal 2015; Wu 2014). Variation in scoring methods and assessment time points made conducting meta-analyses inappropriate. Only two trials showed the superiority of hypertonic saline over normal saline in improving clinical severity scores (Angoulvant 2017; Khanal 2015). Khanal 2015 found that participants who received nebulised hypertonic saline had more significant improvement in baseline clinical severity scores at the end of two hours of treatment. Angoulvant 2017 revealed that the change in Respiratory Distress Assessment Instrument (RDAI) score before and after nebulisation was greater in the hypertonic saline group than that in the normal saline group (adjusted difference $-0.7,95 \% \mathrm{Cl}-1.2$ to $-0.2 ; \mathrm{P}=0.006$ ). Al-Ansari 2010, an emergency department trial, compared nebulised 5\% and $3 \%$ hypertonic saline with nebulised $0.9 \%$ saline, given at enrolment and every four hours thereafter until child was ready for discharge. There was a small but statistically significant lower clinical score favouring treatment with nebulised $5 \%$ saline over nebulised $0.9 \%$ saline at 48 hours after randomisation (3.69 \pm 1.09 versus $4.12 \pm 1.11, \mathrm{P}=0.04$ ) but not 24 hours after randomisation ( $3.75 \pm 1.27$ versus $3.97 \pm 1.40, P=0.38$ ). Al-Ansari 2010 did not find a significant difference in clinical score at 24 hours and 48 hours after randomisation between $3 \%$ saline and $0.9 \%$ saline.

\section{Rate of re-admission to hospital}

Four emergency department trials, Al-Ansari 2010, Anil 2010, Grewal 2009, and Khanal 2015, and one inpatient trial, Everard 2014 , included rate of re-admission after discharge as an outcome. The pooled results of these trials did not demonstrate significant benefits of nebulised hypertonic saline in reducing the risk of readmission (pooled RR 0.77, 95\% Cl 0.48 to $1.25 ; \mathrm{P}=0.30 ; \mathrm{I}^{2}=36 \%$; moderate-quality evidence; Analysis 1.6). 


\section{Haemoglobin saturation (oximetry)}

Eight trials reported the results of haemoglobin saturation (Anil 2010; Florin 2014; Grewal 2009; Ipek 2011; Khanal 2015; Mandelberg 2003; Pandit 2013; Tinsa 2014). Only Khanal 2015 revealed a significant difference between the hypertonic saline group and the $0.9 \%$ saline group in terms of room air saturation of oxyhaemoglobin throughout the study period, showing a significantly higher haemoglobin saturation in the hypertonic saline group than the $0.9 \%$ saline group at 60 minutes and 120 minutes after treatment.

\section{Respiratory rate}

Five trials reported no difference in respiratory rate between the hypertonic saline group and the 0.9\% saline group (Flores 2016; Ipek 2011; Khanal 2015; Pandit 2013; Tinsa 2014).

\section{Heart rate}

Seven trials reported no difference in heart rate between the hypertonic saline group and the $0.9 \%$ saline group (Anil 2010; Florin 2014; Ipek 2011; Khanal 2015; Mandelberg 2003; Pandit 2013; Sarrell 2002).

\section{Time to resolution of symptoms and signs}

Luo 2010 and Luo 2011 reported time to resolution of wheezing, cough, and pulmonary moist crackles. The pooled results showed that infants treated with nebulised $3 \%$ saline had a shorter duration of respiratory symptoms and signs compared to those treated with nebulised $0.9 \%$ saline (pooled MD -1.19 days, $95 \% \mathrm{Cl}-1.54$ to -0.84 $P<0.001)$. There was significant heterogeneity in results between studies $\left(P<0.001 ; I^{2}=77.0 \%\right.$; Analysis 1.7$)$.

\section{Duration of in-hospital oxygen supplementation}

Ojha 2014 and Teunissen 2014 (both inpatient trials) reported no difference in duration of in-hospital oxygen supplementation between the hypertonic saline group and the $0.9 \%$ saline group.

\section{Need for add-on treatment (bronchodilator, systemic corticosteroids, antibiotics, and oxygen supplementation)}

Eight trials compared the need for add-on treatment between treatment groups (Al-Ansari 2010; Flores 2016; Kuzik 2007; Mahesh Kumar 2013; Pandit 2013; Tal 2006; Teunissen 2014; Wu 2014). None of the trials revealed a significant difference between hypertonic saline and $0.9 \%$ saline groups.

\section{Results of pulmonary function tests}

No included studies reported pulmonary function test results.

\section{Radiological findings}

In Mandelberg 2003 and Sarrell 2002 the second chest radiograph was obtained on the third day after hospital admission. The pooled results did not show a significant difference in radiological score between the hypertonic saline and $0.9 \%$ saline groups (pooled MD $-0.08,95 \% \mathrm{Cl}-0.90$ to $0.75 ; \mathrm{P}=0.85$; Analysis 1.8$)$. There was no significant heterogeneity between studies $\left(P=0.95 ; I^{2}=0 \%\right)$.

\section{Adverse events (tachycardia, hypertension, pallor, tremor, nausea, vomiting, diarrhoea, and acute urinary retention)}

Four trials did not report safety data (Ipek 2011; Mahesh Kumar 2013; Miraglia Del Giudice 2012; Ojha 2014). The remaining 24 trials involving 3723 participants reported adverse events in treatment groups. Among the 3723 participants, 1968 received nebulised hypertonic saline ( $3 \%$ saline: $N=1634 ; 5 \%$ saline: $N=165 ; 6 \%$ saline: $N=83 ; 7 \%$ saline: $N=86$ ). Thirteen trials did not find any significant adverse events among a total of 1363 infants, of whom 703 received nebulised hypertonic saline (co-administered with bronchodilators: $\mathrm{N}=672,96 \%$; hypertonic saline alone: $\mathrm{N}$ $=31,4 \%)$. In the remaining 11 trials involving 2360 infants, of whom 1265 received nebulised hypertonic saline (co-administered with bronchodilators: $\mathrm{N}=388,31 \%$; hypertonic saline alone: $\mathrm{N}=$ $877,69 \%)$, at least one adverse event was reported. Variations in reporting and outcomes precluded the possibility of conducting meta-analysis of safety data. We narratively summarised the safety data of 11 trials (Table 5). Various adverse events were reported in both hypertonic saline and control groups; in most cases, these were mild and resolved spontaneously. Only one inpatient trial involving 142 participants who received 3\% saline alone without bronchodilator reported one serious adverse event (bradycardia and desaturation), possibly related to hypertonic saline inhalation, but it resolved the following day.

\section{DISCUSSION}

\section{Summary of main results}

We included 28 trials involving 4195 infants (2222 infants received nebulised hypertonic saline) with acute viral bronchiolitis (17 inpatient trials ( $N=2028) ; 2$ outpatient trials $(N=194) ; 7$ emergency department trials $(\mathrm{N}=1873) ; 1$ outpatient and emergency department trial $(N=100)$ ) (Summary of findings for the main comparison).

Hospitalised infants treated with nebulised hypertonic saline had a statistically significant shorter mean length of hospital stay compared to those treated with nebulised $0.9 \%$ saline (MD -0.41 days, $95 \% \mathrm{Cl}-0.75$ to $-0.07 ; \mathrm{P}=0.02 ; 17$ trials). Children who received hypertonic saline also had a statistically significant lower postinhalation clinical score than the $0.9 \%$ saline group in the first three days of treatment (day $1: \mathrm{MD}-0.77,95 \% \mathrm{Cl}-1.18$ to $-0.36, \mathrm{P}$ $=<0.001$; day 2 : $\mathrm{MD}-1.28,95 \% \mathrm{Cl}-1.91$ to $-0.65, \mathrm{P}<0.001$; day 3 : $\mathrm{MD}-1.43,95 \% \mathrm{Cl}-1.82$ to $-1.04, \mathrm{P}<0.001)$. Nebulised hypertonic saline reduced the risk of hospitalisation by $14 \%$ compared with nebulised $0.9 \%$ saline among children treated as outpatients and in emergency departments (RR $0.86,95 \% \mathrm{Cl} 0.76$ to $0.98 ; \mathrm{P}=0.02 ; 7$ trials). Among eight emergency department trials assessing shortterm effects (30 minutes to 120 minutes) of up to three doses of nebulised hypertonic saline in improving clinical score, only two trials showed significant effects of the treatment.

Post hoc subgroup analyses demonstrated that the effect size of nebulised hypertonic saline on length of stay among inpatients appeared to be greater in subgroups of trials in which virological testing was available, length of stay equal or longer than three days in the control group, use of $3 \%$ hypertonic saline, addition of epinephrine to hypertonic saline solution, and year of publication before 2013. However, the meta-regression analysis did not reveal independent effect of these factors on the effect size of hypertonic saline.

Among children treated as outpatients and in emergency departments, post hoc subgroup analyses revealed that the effect size of nebulised hypertonic saline on reduction of risk of hospitalisation appeared to be greater in subgroups of trials in 
which virological testing was available and multiple doses $(\geq$ two) of saline solution were administered.

Twenty-four trials involving 3723 participants (of which 1968 received nebulised hypertonic saline) reported treatment safety data. Thirteen of these trials did not report any significant adverse events among a total of 1363 infants (of which 703 received nebulised hypertonic saline, mixed with bronchodilators in $96 \%$ of infants). At least one adverse event was reported in 11 trials involving 2360 infants (of which 1265 received nebulised hypertonic saline, alone in $69 \%$ of infants). In most cases, adverse events were mild and resolved spontaneously.

\section{Overall completeness and applicability of evidence}

In this update, we found that the effect size of nebulised hypertonic saline on reducing length of stay in hospitalised infants was approximately a third of what was found in the last (2013) update of this review. Zhang 2013 included six inpatient trials involving 500 infants (MD -1.15 days, $95 \% \mathrm{Cl}-1.49$ to -0.82 days). Moreover, all 10 trials published in 2013 and thereafter, including two European multicentre studies with relatively large sample sizes, did not find significant effects of nebulised hypertonic saline on length of stay among inpatients with bronchiolitis. We found two main differences between recently published trials and those published before 2013. Virological investigation was available in $86 \%$ of trials published before 2013, whereas such testing was available in only $30 \%$ of trials published in 2013 and thereafter. Another difference was that none of the seven older trials had a mean length of stay in the control group of less than three days, while $40 \%$ of the recently published trials had a mean length of stay in the control group of less than three days. These two factors may partially explain the inconsistency in results between older trials and trials published in 2013 and thereafter; however, the meta-regression analysis did not confirm an independent effect of these factors on the effect size of hypertonic saline.

For outpatients and emergency department patients, we found a $14 \%$ (RR $0.86,95 \% \mathrm{Cl} 0.76$ to 0.98 ) reduction in the risk of hospitalisation associated with nebulised hypertonic saline, in contrast with a $37 \%$ non-statistically significant reduction shown in the 2013 review, which included four outpatient and emergency department trials involving 380 infants (RR $0.63,95 \% \mathrm{Cl} 0.37$ to 1.07).

Clinical score is generally considered a relatively objective measure to assess the severity of illness. In this review, 11 trials used the clinical severity score system proposed by Wang 1992, which assesses respiratory rate, wheezing, retraction, and general condition. The benefits of nebulised hypertonic saline in improving clinical score were observed in the first three days of treatment in both outpatients and inpatients. However, most emergency department trials failed to demonstrate significant effects of hypertonic saline in improving clinical score over a short period of time (30 minutes to 120 minutes). The validity of Wang 1992 score system has not yet been assessed. Another commonly used approach for grading clinical severity was the Respiratory Distress Assessment Instrument (RDAI). However, RDAI may have poor to moderate construct validity, considerable test-retest measurement error, and does not encompass all determinants of bronchiolitis severity (Fernandes 2015).
Potential side effects, principally acute bronchospasm, remain a concern with nebulised hypertonic saline. No significant adverse events were observed in 13 trials involving 1363 infants (703 treated with nebulised hypertonic saline). Saline solutions were co-administered with bronchodilators in $96 \%$ of these infants. In contrast, there were 11 trials involving 2360 participants (1265 treated with nebulised hypertonic saline) reported at least one adverse event. The majority of patients $(69 \%)$ received saline solution alone. Most adverse events were mild and resolved spontaneously. These results suggest that nebulised hypertonic saline is a safe treatment in infants with bronchiolitis, especially when administered in conjunction with a bronchodilator.

Inhalation therapy was administrated via jet nebulisers in all of the included studies except for Tal 2006, which used ultrasonic nebulisers. There are some theoretical differences in the physical properties of aerosols produced by jet nebulisers and ultrasonic nebulisers, which may affect their therapeutic efficacy. On the one hand, ultrasonic nebulisers induce sputum more efficiently than jet nebulisers; on the other hand, jet nebulisers generate aerosols with smaller aerodynamic mass median diameter, which may more easily reach smaller bronchi and bronchioles. We could not provide direct evidence regarding the impact of the physical properties of aerosols generated by different types of nebulisers on the efficacy of inhaled hypertonic saline in infants with viral bronchiolitis. However, at least one trial demonstrated that both jet nebulisers and ultrasonic nebulisers are efficient methods of delivery of hypertonic saline for infants with bronchiolitis (Tal 2006).

The optimal treatment regimen for nebulised hypertonic saline in acute bronchiolitis remains unclear. Among inpatients, study solutions were given more frequently in 12 trials (every 4 to 6 hours) and less frequently in 5 trials (every 8 hours). Subgroup analysis did not reveal a significant difference in reduction of length of hospital stay between regimens. Among outpatients and emergency department patients, effect size of nebulised hypertonic saline appeared to be greater when multiple doses ( $\geq$ two) of saline solutions were administered compared to a single dose.

The concentration of nebulised hypertonic saline was 3\% in all but five trials (Al-Ansari 2010; Köse 2016; Li 2014; Teunissen 2014; Tinsa 2014). We did not observe the superiority of higher concentration $(5 \%, 6 \%$, and $7 \%$ ) of hypertonic saline over $3 \%$ saline in improving clinical outcomes. On the contrary, subgroup analysis showed a larger effect of 3\% saline on reducing length of hospital stay among inpatients compared to hypertonic saline with higher concentration.

We included trials conducted in high- and low-income countries and in different settings (inpatient, outpatient, and emergency department). The evidence derived from this review thus may have wide applicability. However, as all but two included trials only recruited infants with mild to moderate bronchiolitis (Teunissen 2014; Wu 2014), care should be taken when extrapolating the findings of this review to infants with more severe bronchiolitis, such as those requiring mechanical ventilation, intensive care, or with oxygen saturation readings below $85 \%$ on room air. The underlying airway pathological changes may differ between severe and mild to moderate bronchiolitis, so different responses to treatments with hypertonic saline may be expected in children with more severe illness. Further trials are needed to assess the potential 
effects of nebulised hypertonic saline in infants hospitalised with severe acute bronchiolitis.

Despite our findings that the effects of nebulised hypertonic saline on reduction in length of hospital stay are smaller than were previously estimated, a reduction of 10 hours in length of hospital stay in infants with bronchiolitis may still be considered clinically relevant given the relatively short disease course, high prevalence, and huge burden of illness on healthcare systems around the world. Moreover, nebulised hypertonic saline may have benefits on other outcomes such as rate of hospitalisation and clinical severity score in infants with acute bronchiolitis, providing a good safety profile and low cost.

\section{Quality of the evidence}

We had no serious concerns on three domains of the GRADE approach (indirectness, imprecision, and publication bias). We downgraded the quality of the evidence to low for length of hospital stay due to high levels of statistical heterogeneity and potential risk of selection bias in one-third of the included trials. High heterogeneity could be expected given variations among trials in definitions of acute bronchiolitis, disease severity, standard care, intervention regimen, criteria for discharge, and risk of potential bias. We conducted several subgroup analyses to investigate the potential sources of heterogeneity, but moderate to high levels of heterogeneity persisted in most subgroup analyses.

We downgraded the quality of the evidence to low for clinical severity score due to high heterogeneity and risk of bias, as mentioned above.

In spite of the fact that there was no statistically significant heterogeneity, we downgraded the quality of evidence to moderate for rate of hospitalisation due to substantial clinical heterogeneity between studies.

\section{Potential biases in the review process}

We searched for both published and unpublished trials to identify all relevant studies. We obtained additional trial data from five principal investigators. All included inpatient trials contributed data for meta-analysis of length of hospital stay. However, the results of meta-analyses of some secondary outcomes, such as clinical severity score and rate of re-admission, may be biased because only some included trials contributed data for analysis. The number of trials and participants in outpatient and emergency department settings was limited: Wu 2014 and Angoulvant 2017 contributed $73 \%$ of weight to the overall summary estimate of effects of hypertonic saline on reduction of risk of hospitalisation. All studies except for Everard 2014 used 0.9\% saline as the comparison. The use of normal saline enables the trial to be double-blind, however normal saline is not technically a placebo, as high-volume normal saline inhalation could potentially have physiological effects by improving airway mucociliary clearance, which may have beneficial effects on acute bronchiolitis (Wohl 2003). Use of normal saline as the control may tend to minimise the effect size of hypertonic saline.

\section{Agreements and disagreements with other studies or reviews}

Four published systematic reviews addressed efficacy and safety of nebulised hypertonic saline in children with acute bronchiolitis (Badgett 2015; Chen 2014; Maguire 2015; Zhang 2015). We comparatively summarised the main findings of these four reviews in Table 6.

\section{AUTHORS'CONCLUSIONS}

\section{Implications for practice}

Current evidence suggests that nebulised hypertonic saline may modestly reduce the length of hospital stay among infants hospitalised with acute viral bronchiolitis and improve clinical severity scores. Nebulised hypertonic saline may also reduce the risk of hospitalisation among outpatients and emergency department patients. Treatment with nebulised hypertonic saline has a good safety profile. However, the quality of evidence in this review was insufficient to support routine use of nebulised hypertonic saline in infants with acute bronchiolitis.

\section{Implications for research}

Further multicentre randomised trials are required to evaluate the efficacy and safety of nebulised hypertonic saline in infants with acute bronchiolitis, in inpatient, outpatient, and emergency department settings. There are some common challenges for all clinical trials in infants with acute bronchiolitis. The currently used definition of 'bronchiolitis' may include a heterogeneous group of patients with different underlying aetiologies and pathologies. The development of valid diagnostic criteria for acute bronchiolitis in infants is urgently needed. There is a lack of robust and wellaccepted efficacy outcome measures. Length of hospital stay and rate of hospitalisation are the most clinically important endpoints, but they are usually more susceptible to bias. Well-defined valid admission and discharge criteria should thus be used. Further trials should have sufficient statistical power to detect modest but clinically relevant effects of the intervention. The optimal treatment regimen of nebulised hypertonic saline for infants with acute bronchiolitis remains to be determined. The mechanism of action of nebulised hypertonic saline in infants with viral bronchiolitis also needs to be addressed in future studies.

\section{ACK N OWLEDGEMENTS}

Thanks to Ruth Foxlee, Sarah Thorning, Justin Clark, and David Honeyman for help in defining the search strategy and running literature searches. Thanks also to Libby Lissiman for assistance in the early stages of this review and to the Cochrane Acute Respiratory Infections Group, especially Liz Dooley and Ann Jones, for editorial assistance. The authors wish to thank the following people for commenting on drafts of this review: Hayley Edmonds, Avigdor Mandelberg, Federico Martinón Torres, Sree Nair, Amy Zelmer, Karen Lee, Anne Lyddiatt, Federico Martinón Torres, and Meenu Singh. 


\section{RE F E R E N C E S}

\section{References to studies included in this review}

Al-Ansari 2010 \{published data only\}

Al-Ansari K, Sakran M, Davidson BL, Sayyed RE, Mahjoub H, Ibrahim K. Nebulized $5 \%$ or $3 \%$ hypertonic or $0.9 \%$ saline for treating acute bronchiolitis in infants. Journal of Pediatrics 2010;157(4):630-4

\section{Angoulvant 2017 \{published data only\}}

Angoulvant F, Bellêttre X, Milcent K, Teglas JP, Claudet I, Le Guen CG, et al. Effect of nebulized hypertonic saline treatment in emergency departments on the hospitalization rate for acute bronchiolitis: a randomized clinical trial. JAMA Pediatrics 2017;171(8):e171333. [DOI: 10.1001/ jamapediatrics.2017.1333]

\section{Anil 2010 \{published data only\}}

Anil AB, Anil M, Saglam AB, Cetin N, Bal A, Aksu N. High volume normal saline alone is as effective as nebulized salbutamolnormal saline, epinephrine-normal saline, and 3\% saline in mild bronchiolitis. Pediatric Pulmonology 2010;45(1):41-7.

\section{Everard 2014 \{published data only\}}

Everard ML, Hind D, Ugonna K, Freeman J, Bradburn M, Cooper $\mathrm{CL}$, et al. SABRE: a multicentre randomised control trial of nebulised hypertonic saline in infants hospitalised with acute bronchiolitis. Thorax 2014;69(12):1105-12. [DOI: 10.1136/ thoraxjnl-2014-205953]

\section{Flores 2016 \{published data only\}}

Flores P, Mendes AL, Neto AS. A randomized trial of nebulized $3 \%$ hypertonic saline with salbutamol in the treatment of acute bronchiolitis in hospitalized infants. Pediatric Pulmonology 2016;51(4):418-25. [DOI: 10.1002/ppul.23306]

\section{Florin 2014 \{published data only\}}

Florin TA, Shaw KN, Kittick M, Yakscoe S, Zorc JJ. Nebulized hypertonic saline for bronchiolitis in the emergency department: a randomized clinical trial. JAMA Pediatrics 2014;168(7):664-70.

\section{Grewal 2009 \{published data only\}}

Grewal S, Ali S, McConnell DW, Vandermeer B, Klassen TP. A randomized trial of nebulized $3 \%$ hypertonic saline with epinephrine in the treatment of acute bronchiolitis in the emergency department. Archives of Pediatrics \& Adolescent Medicine 2009;163(11):1007-12.

\section{Ipek 2011 \{published data only\}}

Ipek IO, Yalcin EU, Sezer RG, Bozaykut A. The efficacy of nebulized salbutamol, hypertonic saline and salbutamol/ hypertonic saline combination in moderate bronchiolitis. Pulmonary Pharmacology \& Therapeutics 2011;24(6):633-7.

\section{Jacobs 2014 \{published data only\}}

Jacobs JD, Foster M, Wan J, Pershad J. 7\% hypertonic saline in acute bronchiolitis: a randomized controlled trial. Pediatrics 2014;133(1):e8-13.
Khanal 2015 \{published data only\}

Khanal A, Sharma A, Basnet S, Sharma PR, Gami FC. Nebulised hypertonic saline (3\%) among children with mild to moderately severe bronchiolitis - a double blind randomized controlled trial. BMC Pediatrics 2015;15:115. [DOI: 10.1186/ s12887-015-0434-4]

\section{Köse 2016 \{published data only\}}

Köse S, Şehriyaroğlu A, Esen F, Özdemir A, Kardaş Z, Altuğ U, et al. Comparing the efficacy of $7 \%, 3 \%$ and $0.9 \%$ saline in moderate to severe bronchiolitis in infants. Balkan Medical Journal 2016;33(2):193-7.

\section{Kuzik 2007 \{published data only\}}

Kuzik BA, Al Qaghi SA, Kent S, Flavin MP, Hopman W, Hotte S, et al. Nebulized hypertonic saline in the treatment of viral bronchiolitis in infants. Journal of Pediatrics 2007;151(3):266-70.

\section{Li 2014 \{published data only\}}

Li G, Zhao J. Effectiveness of inhaled hypertonic saline in children with bronchiolitis. Zhonghua Er Ke Za Zh 2014;25(8):607-10.

\section{Luo 2010 \{published data only\}}

Luo Z, Liu E, Luo J, Li S, Zeng F, Yang X, et al. Nebulized hypertonic saline/salbutamol solution treatment in hospitalized children with mild to moderate bronchiolitis. Pediatrics International 2010;52(2):199-202.

\section{Luo 2011 \{published data only\}}

Luo Z, Fu Z, Liu E, Xu X, Fu X, Peng D, et al. Nebulized hypertonic saline treatment in hospitalized children with moderate to severe viral bronchiolitis. Clinical Microbiology and Infection 2011:17(12):1829-33.

\section{Mahesh Kumar 2013 \{published data only\}}

Mahesh Kumar KB, Karunakara BP, Manjunath MN, Mallikarjuna HB. Aerosolised hypertonic saline in hospitalized young children with acute bronchiolitis: a randomized controlled clinical trial. Journal of Pediatric Sciences 2013;5(1):e174.

Mandelberg 2003 \{published data only\} Mandelberg A, Tal G, Witzling M, Someck E, Houri S, Balin A, et al. Nebulized $3 \%$ hypertonic saline solution treatment in hospitalized infants with viral bronchiolitis. Chest 2003;123(2):481-7.

\section{Miraglia Del Giudice 2012 \{published data only\}}

Miraglia Del Giudice M, Saitta F, Leonardi S, Capasso M, Niglio B, Chinellato I, et al. Effectiveness of nebulized hypertonic saline and epinephrine in hospitalized infants with bronchiolitis. International Journal of Immunopathology and Pharmacology 2012;25(2):485-91.

NCT01238848 \{unpublished data only\}

NCT01238848. Efficacy of nebulized hypertonic saline in the treatment of acute bronchiolitis [A randomized controlled trial to evaluate efficacy of nebulized hypertonic saline vs. 
normal saline in the treatment of hospitalized children with bronchiolitis]. clinicaltrials.gov/ct2/show/NCT01238848 (first received 11 November 2010).

\section{Ojha 2014 \{published data only\}}

Ojha AR, Mathema S, Sah S, Aryal UR. A comparative study on use of $3 \%$ saline versus $0.9 \%$ saline nebulization in children with bronchiolitis. Journal of Nepal Health Research Council 2014;12(26):39-43.

\section{Pandit 2013 \{published data only\}}

Pandit S, Dhawan N, Thakur D. Utility of hypertonic saline in the management of acute bronchiolitis in infants: a randomized controlled study. International Journal of Clinical Pediatrics 2013;2(1):24-9.

\section{Ratajczyk-Pekrul 2016 \{published data only\}}

Ratajczyk-Pekrul K, Gonerko P, Peregud-Pogorzelski J. The clinical use of hypertonic saline/salbutamol in treatment of bronchiolitis. Pediatria Polska 2016;91(4):301-7.

\section{Sarrell 2002 \{published data only\}}

Sarrell EM, Tal G, Witzling M, Someck E, Houri S, Cohen HA, et al. Nebulized 3\% hypertonic saline solution treatment in ambulatory children with viral bronchiolitis decreases symptoms. Chest 2002;122(6):2015-20.

\section{Sharma 2013 \{published data only\}}

Sharma BS, Gupta MK, Rafik SP. Hypertonic (3\%) saline for acute viral bronchiolitis: a randomized trial. Indian Pediatrics 2013;50(8):743-7.

\section{Tal 2006 \{published data only\}}

Tal G, Cesar K, Oron A, Houri S, Ballin A, Mandelberg A. Hypertonic saline/epinephrine treatment in hospitalized infants with viral bronchiolitis reduces hospitalization stay: 2 years experience. Israel Medical Association Journal 2006;8(3):169-73.

\section{Teunissen 2014 \{published data only\}}

Teunissen J, Hochs AH, Vaessen-Verberne A, Boehmer AL, Smeets CC, Brackel $\mathrm{H}$, et al. The effect of $3 \%$ and $6 \%$ hypertonic saline in viral bronchiolitis: a randomised controlled trial. European Respiratory Journal 2014;44(4):913-21.

\section{Tinsa 2014 \{published data only\}}

Tinsa F, Abdelkafi S, Bel Haj I, Hamouda S, Brini I, Zouari B, et al. A randomized, controlled trial of nebulized $5 \%$ hypertonic saline and mixed $5 \%$ hypertonic saline with epinephrine in bronchiolitis. La Tunisie Medicale 2014;92(11):674-7.

\section{Wu 2014 \{published data only\}}

Wu S, Baker C, Lang ME, Schrager SM, Liley FF, Papa C, et al. Nebulized hypertonic saline for bronchiolitis: a randomized clinical trial. JAMA Pediatrics 2014;168(7):657-63.

\section{References to studies excluded from this review}

\section{Al-bahadily 2017 \{published data only\}}

Al-bahadily AJM, Al-Omrani AAM, Atiya AA. Hypertonic 3\% saline in comparison with $0.9 \%$ (normal) saline in treatment of acute bronchiolitis. International Journal of Pediatrics 2017;5(1):4209-16.

\section{Amirav 2005 \{published data only\}}

Amirav I, Oron A, Tal G, Cesar K, Ballin A, Houri S, et al. Aerosol delivery in RSV bronchiolitis: hood or face-mask?. Journal of Pediatrics 2005;147(5):627-31.

\section{Bagus 2012 \{published data only\}}

Bagus SI, Putu SP. Efficacy of nebulized hypertonic saline and albuterol combination for the management of acute bronchiolitis: a randomized, double-blind controlled trial. Paediatric Respiratory Reviews 2012;13(Suppl 1):S76.

\section{Bueno Campaña 2014 \{published data only\}}

Bueno Campaña M, Olivares Ortiz J, Notario Muñoz C, Rupérez Lucas M, Fernández Rincón A, Patiño Hernández $\mathrm{O}$, et al. High flow therapy versus hypertonic saline in bronchiolitis: randomised controlled trial. Archives of Disease in Childhood 2014;99(6):511-5.

\section{Flores-González 2015 \{published data only\}}

Flores-González JC, Matamala-Morillo MA, Rodríguez-Campoy P, Pérez-Guerrero JJ, Serrano-Moyano B, Comino-Vazquez P, et al. Epinephrine improves the efficacy of nebulized hypertonic saline in moderate bronchiolitis: a randomised clinical trial. PLOS ONE 2015;10(11):e0142847.

\section{Flores-González 2016 \{published data only\}}

Flores-González JC, Dominguez-Coronel MT, Matamala Morillo MA, Aragón Ramírez M, García Ortega RM, Dávila Corrales FJ, et al. Does nebulized epinephrine improve the efficacy of hypertonic saline solution in the treatment of hospitalized moderate acute bronchiolitis? A double blind, randomized clinical trial. Minerva Pediatrica 2016;68(2):81-8.

\section{Guomo 2007 \{published data only\}}

Guomo R, Cossettini M, Saretta F, Fasoli L, Guerrera T, Canciani M. Efficacy of hypertonic saline solution in infants with acute bronchiolitis. European Respiratory Journal 2007;30(Suppl):E3016.

\section{Gupta 2016 \{published data only\}} Gupta HV, Gupta VV, Kaur G, Baidwan AS, George PP, Shah JC, et al. Effectiveness of 3\% hypertonic saline nebulization in acute bronchiolitis among Indian children: a quasi experimental study. Perspectives in Clinical Research 2016;7(2):88-93.

Kuzik 2010 \{published data only\}

Kuzik BA, Flavin MP, Kent S, Zielinski D, Kwan CW, Adeleye A, et al. Effect of inhaled hypertonic saline on hospital admission rate in children with viral bronchiolitis: a randomized trial. Canadian Journal of Emergency Medicine 2010;12(6):477-84.

\section{Malik 2015 \{published data only\}}

Malik G, Singh A, Singh K, Pannu MS, Singh P, Banga S, et al. A comparative study to assess the effects of nebulised $3 \%$ hypertonic saline, $0.9 \%$ normal saline and salbutamol in management of acute bronchiolitis among Indian children. Journal of Evolution of Medical and Dental Sciences 2015;4(21):3662-8. 
Nenna 2014 \{published data only\}

Nenna R, Papoff P, Moretti C, De Angelis D, Battaglia M, Papasso S, et al. Seven percent hypertonic saline - $0.1 \%$ hyaluronic acid in infants with mild-to-moderate bronchiolitis. Pediatric Pulmonology 2014;49(9):919-25.

Silver 2015 \{published data only\}

Silver AH, Esteban-Cruciani N, Azzarone G, Douglas LC, Lee DS, Liewehr S, et al. 3\% hypertonic saline versus normal saline in inpatient bronchiolitis: a randomized controlled trial. Pediatrics 2015;136(6):1036-43.

Tribastone 2003 \{published data only\}

Tribastone AD. Nebulized 3\% saline effective for viral bronchiolitis. Journal of Family Practice 2003;52(5):359-60.

\section{References to studies awaiting assessment}

\section{CTRI/2010/091/003065 \{unpublished data only\}}

CTRI/2010/091/003065. A clinical trial to study the effect of nebulized hypertonic saline as compared to normal saline in infants and children with bronchiolitis [Study of nebulized hypertonic saline in the treatment of bronchiolitis in infants and children]. ctri.nic.in/Clinicaltrials/pmaindet2.php?trialid=2459 (first received 1 November 2011).

\section{EudraCT2009-014758-14 \{unpublished data only\}}

EudraCT2009-014758-14. Nebulised hypertonic (3\%) saline in the treatment of bronchiolitis [Does nebulised hypertonic (3\%) saline reduce the duration of hospital admission in infants with bronchiolitis?]. https://www.clinicaltrialsregister.eu/ctr-search/ trial/2009-014758-14/GB (first received 17 March 2010).

\section{NCT00677729 \{unpublished data only\}}

NCT00677729. Hypertonic saline to reduce hospital admissions in bronchiolitis [Inhaled hypertonic saline to reduce hospital admissions in infants with viral bronchiolitis (HS in ER study)]. clinicaltrials.gov/ct2/show/NCT00677729 (first received 2 May 2008)

\section{NCT01777347 \{unpublished data only\}}

NCT01777347. Efficacy of 3\% hypertonic saline in acute viral bronchiolitis (GUERANDE) [3\% hypertonic saline to reduce hospitalization rate in acute viral bronchiolitis: a randomized double blind clinical trial]. clinicaltrials.gov/ct2/show/ NCT01777347 (first received 14 November 2012).

\section{NCT01834820 \{unpublished data only\}}

NCT01834820. Epinephrine, dexamethasone, and hypertonic saline in bronchiolitis, randomised clinical trial of efficacy and safety [Pilot study: epinephrine, dexamethasone, and hypertonic saline in children with bronchiolitis, randomised clinical trial of efficacy and safety]. clinicaltrials.gov/ct2/show/ NCT01834820 (first received 15 January 2013).

\section{NCT02029040 \{unpublished data only\}}

NCT02029040. Nebulized 3\% hypertonic saline in the treatment of acute bronchiolitis [A randomized trial of nebulized 3\% hypertonic saline in the treatment of acute bronchiolitis in the emergency department]. clinicaltrials.gov/ct2/show/ NCT02029040 (first received 3 January 2014).

NCT02045238 \{unpublished data only\}

NCT02045238. Inhaled hypertonic saline use in the emergency department to treat acute viral bronchiolitis [Study of the effect of inhaled 3\% hypertonic saline compared with normal saline $(0.9 \%)$ for the treatment of acute viral bronchiolitis in a short stay ward]. clinicaltrials.gov/ct2/show/NCT02045238 (first received 22 January 2014).

\section{NCT02233985 \{unpublished data only\}}

NCT02233985. Nebulized 3\% hypertonic saline solution treatment of bronchiolitis in infants [A randomized trial of nebulized $3 \%$ hypertonic saline with salbutamol in the treatment of acute bronchiolitis in pediatric hospital]. clinicaltrials.gov/ct2/show/NCT02233985 (first received 7 May 2014).

\section{NCT02834819 \{unpublished data only\}}

NCT02834819. Nebulized 3\% hypertonic saline vs. standard of care in patients with bronchiolitis [A randomized controlled trial of nebulized $3 \%$ hypertonic saline vs. standard of care in patients with bronchiolitis]. clinicaltrials.gov/ct2/show/ NCT02834819 (first received 15 July 2016).

\section{Additional references}

\section{Assouline 1977}

Assouline G, Leibson V, Danon A. Stimulation of prostaglandin output from rat stomach by hypertonic solution. European Journal of Pharmacology 1977;44(3):271-3.

\section{Atkins 2004}

Atkins D, Best D, Briss PA, Eccles M, Falck-Ytter Y, Flottorp S, et al. GRADE Working Group. Grading quality of evidence and strength of recommendations. BMJ 2004;328(7454):1490.

\section{Badgett 2015}

Badgett RG, Vindhyal M, Stirnaman JT, Gibson CM, Halaby R. A living systematic review of nebulized hypertonic saline for acute bronchiolitis in infants. JAMA Pediatrics 2015;169(8):788-9.

\section{Bertrand 2001}

Bertrand P, Aranibar H, Castro E, Sanchez I. Efficacy of nebulized epinephrine versus salbutamol in hospitalized infants with bronchiolitis. Pediatric Pulmonology 2001;31(4):284-8.

\section{Chen 2014}

Chen YJ, Lee WL, Wang CM, Chou HH. Nebulized hypertonic saline treatment reduces both rate and duration of hospitalization for acute bronchiolitis in infants: an updated meta-analysis. Pediatrics and Neonatology 2014;55(6):431-8.

\section{Daviskas 1996}

Daviskas E, Anderson SD, Gonda I, Eberl S, Meikle S, Seale JP, et al. Inhalation of hypertonic saline aerosol enhances mucociliary clearance in asthmatic and healthy subjects. European Respiratory Journal 1996;9(4):725-32. 


\section{Dickersin 1994}

Dickersin K, Scherer R, Lefebvre C. Identifying relevant studies for systematic reviews. BMJ 1994;309:1286-91.

\section{Enriquez 2012}

Enriquez A, Chu IW, Mellis C, Lin WY. Nebulised deoxyribonuclease for viral bronchiolitis in children younger than 24 months. Cochrane Database of Systematic Reviews 2012, Issue 11. [DOI: 10.1002/14651858.CD008395.pub2]

\section{Fernandes 2015}

Fernandes RM, Plint AC, Terwee CB, Sampaio C, Klassen TP, Offringa M, et al. Validity of bronchiolitis outcome measures. Pediatrics 2015;135(6):e1399-408.

\section{García-García 2006}

García-García ML, Calvo C, Pérez-Breña P, De Cea JM, Acosta B, Casas I. Prevalence and clinical characteristics of human metapneumovirus infections in hospitalized infants in Spain. Pediatric Pulmonology 2006;41(9):863-71.

\section{GRADEpro GDT 2014 [Computer program]}

GRADE Working Group, McMaster University. GRADEpro GDT. Version 2014. Hamilton (ON): GRADE Working Group, McMaster University, 2014.

\section{Hartling 2011}

Hartling L, Bialy LM, Vandermeer B, Tjosvold L, Johnson DW, Plint AC, et al. Epinephrine for bronchiolitis. Cochrane Database of Systematic Reviews 2011, Issue 6. [DOI: 10.1002/14651858.CD003123.pub3]

\section{Henderson 1979}

Henderson FW, Clyde WA Jr, Collier AM, Denny FW, Senior RJ, Sheaffer $\mathrm{Cl}$, et al. The etiologic and epidemiologic spectrum of bronchiolitis in pediatric practice. Journal of Pediatrics 1979;95(2):183-90.

\section{Higgins 2003}

Higgins JPT, Thompson SG, Deeks JJ, Altman DG. Measuring inconsistency in meta-analysis. BMJ 2003;327:557-60.

\section{Higgins 2011}

Higgins JPT, Green S (editors). Cochrane Handbook for Systematic Reviews of Interventions Version 5.1.0 [updated March 2011]. The Cochrane Collaboration, 2011. Available from handbook.cochrane.org.

\section{Jacques 2006}

Jacques J, Bouscambert-Duchamp M, Moret H, Carquin J, Brodard V, Lina B, et al. Association of respiratory picornaviruses with acute bronchiolitis in French infants. Journal of Clinical Virology 2006;25(4):463-6.

\section{Kellett 2005}

Kellett F, Redfern J, Niven RM. Evaluation of nebulised hypertonic saline $(7 \%)$ as an adjunct to physiotherapy in patients with stable bronchiectasis. Respiratory Medicine 2005;99(1):27-31.

\section{Klassen 1997a}

Klassen TP. Recent advances in the treatment of bronchiolitis and laryngitis. Pediatric Clinics of North America 1997;44(1):249-61.

\section{Klassen 1997b}

Klassen TP, Sutcliffe T, Watters LK, Wells GA, Allen UD, Li MM. Dexamethasone in salbutamol-treated inpatients with acute bronchiolitis: a randomized, controlled trial. Journal of Pediatrics 1997;130(2):191-6.

\section{Maguire 2015}

Maguire C, Cantrill H, Hind D, Bradburn M, Everard M. Hypertonic saline (HS) for acute bronchiolitis: systematic review and meta-analysis. BMC Pulmonary Medicine 2015;15:148. [DOI: 10.1186/s12890-015-0140-x]

\section{Mandelberg 2010}

Mandelberg A, Amirav I. Hypertonic saline or high volume normal saline for viral bronchiolitis: mechanisms and rationale. Pediatric Pulmonology 2010;45(1):36-40.

\section{Meissner 2003}

Meissner HC. Selected populations at increased risk from respiratory syncytial virus infection. Pediatric Infectious Disease Journal 2003;22(Suppl 2):40-4.

\section{Nasr 2001}

Nasr SZ, Strouse PJ, Soskoline E, Maxvold NJ, Garver KA, Rubin BK, et al. Efficacy of recombinant human deoxyribonuclease I in the hospital management of respiratory syncytial virus bronchiolitis. Chest 2001;120(1):203-8.

\section{Panitch 1993}

Panitch HB, Callahan CW, Schidlow DV. Bronchiolitis in children. Clinics in Chest Medicine 1993;14(4):715-31.

\section{Panitch 2003}

Panitch HB. Respiratory syncytial virus bronchiolitis: supportive care and therapies designed to overcome airway obstruction. Pediatric Infectious Disease Journal 2003;22(Suppl):83-8.

\section{Rakshi 1994}

Rakshi K, Couriel JM. Management of acute bronchiolitis. Archives of Disease in Childhood 1994;71(5):463-9.

\section{RevMan 2014 [Computer program]}

The Nordic Cochrane Centre, The Cochrane Collaboration. Review Manager (RevMan). Version 5.3. Copenhagen: The Nordic Cochrane Centre, The Cochrane Collaboration, 2014.

\section{Robinson 1997}

Robinson M, Hemming A, Regnis J, Wong A, Bailey D, Bautotvich GJ, et al. Effect of increasing doses of hypertonic saline on mucociliary clearance in patients with cystic fibrosis. Thorax 1997;52(10):900-3.

\section{Roqué i Figuls 2016}

Roqué i Figuls M, Giné-Garriga M, Granados Rugeles C, Perrotta C, Vilaró J. Chest physiotherapy for acute bronchiolitis in paediatric patients between 0 and 24 months old. 
Cochrane Database of Systematic Reviews 2016, Issue 2. [DOI: 10.1002/14651858.CD004873.pub5]

\section{Rose 1987}

Rose RM, Pinkston P, O'Donnell C, Jensen WA. Viral infection of the lower respiratory tract. Clinical Chest Medicine 1987;8:405-18.

\section{Schuh 1992}

Schuh S, Johnson D, Canny G, Reisman J, Shields M, Kovesi T, et al. Efficacy of adding nebulized ipratropium bromide to nebulized albuterol therapy in acute bronchiolitis. Pediatrics 1992;90(6):920-3.

\section{Shay 1999}

Shay DK, Holman RC, Newman RD, Liu LL, Stout JW, Anderson LJ. Bronchiolitis hospitalizations. JAMA 1999;282(15):1440-6.

\section{Shay 2001}

Shay DK, Holman RC, Roosevelt GE, Clarke MJ, Anderson LJ. Bronchiolitis-associated mortality and estimates of respiratory syncytial virus-associated deaths among US children 1979-1997. Journal of Infectious Diseases 2001;183(1):16-22.

\section{Shi 2017}

Shi T, McAllister DA, O'Brien KL, Simoes EAF, Madhi SA, Gessner BD, et al. Global, regional, and national disease burden estimates of acute lower respiratory infections due to respiratory syncytial virus in young children in 2015: a systematic review and modelling study. Lancet 2017;390(10098):946-58.

\section{Shoseyov 1998}

Shoseyov D, Bibi H, Shai P, Ahoseyov N, Shazberg G, Hurvitz H. Treatment with hypertonic saline versus normal saline nasal wash of pediatric chronic sinusitis. Journal of Allergy and Clinical Immunology 1998;101(5):602-5.

\section{StataCorp 2009 [Computer program]}

StataCorp LP. Stata Statistical Software. Version 11. College Station, TX: StataCorp LP, 2009.

\section{Wainwright 2003}

Wainwright C, Altamirano L, Cheney M, Cheney J, Barber S, Price D, et al. A multicenter, randomized, double-blind, controlled trial of nebulized epinephrine in infants with acute bronchiolitis. New England Journal of Medicine 2003;349(1):27-35.

\section{Wan 2014}

Wan X, Wang W, Liu J, Tong T. Estimating the sample mean and standard deviation from the sample size, median, range and/or interquartile range. BMC Medical Research Methodology 2014;14:135. [DOI: 10.1186/1471-2288-14-135]

\section{Wang 1992}

Wang EE, Milner RA, Navas L, Maj H. Observer agreement for respiratory signs and oximetry in infants hospitalized with lower respiratory infections. American Review of Respiratory Diseases 1992;145(1):106-9.

\section{Wark 2009}

Wark PAB, McDonald V. Nebulised hypertonic saline for cystic fibrosis. Cochrane Database of Systematic Reviews 2009, Issue 2. [DOI: 10.1002/14651858.CD001506.pub2]

\section{Wohl 1978}

Wohl MEB, Chernick V. State of the art: bronchiolitis. American Review of Respiratory Diseases 1978;118(4):759-81.

\section{Wohl 2003}

Wohl ME, Chernick VC. Treatment of acute bronchiolitis. New England Journal of Medicine 2003;349(1):82-3.

\section{Zhang 2003}

Zhang L, Ferruzzi E, Bonfanti T, Auler MI, Davila NE, Faria CS, et al. Long and short-term effect of prednisolone in hospitalized infants with acute bronchiolitis. Journal of Paediatrics and Child Health 2003;39(7):548-51.

\section{Ziment 1978}

Ziment I. Respiratory Pharmacology and Therapeutics. Philadelphia: WB Saunders, 1978.

\section{References to other published versions of this review}

\section{Zhang 2008}

Zhang L, Mendoza-Sassi RA, Wainwright C, Klassen TP. Nebulized hypertonic saline solution for acute bronchiolitis in infants. Cochrane Database of Systematic Reviews 2008, Issue 4. [DOI: 10.1002/14651858.CD006458.pub2]

\section{Zhang 2011}

Zhang L, Mendoza-Sassi RA, Wainwright C, Klassen TP. Nebulized hypertonic saline solution for acute bronchiolitis in infants. Cochrane Database of Systematic Reviews 2011, Issue 3. [DOI: 10.1002/14651858.CD006458.pub2]

\section{Zhang 2013}

Zhang L, Mendoza-Sassi RA, Wainwright C, Klassen TP. Nebulised hypertonic saline solution for acute bronchiolitis in infants. Cochrane Database of Systematic Reviews 2013, Issue 7. [DOI: 10.1002/14651858.CD006458.pub3]

\section{Zhang 2015}

Zhang L, Mendoza-Sassi RA, Klassen TP, Wainwright C. Nebulized hypertonic saline for acute bronchiolitis: a systematic review. Pediatrics 2015;136(4):687-701.

\section{Zhang 2016}

Zhang L, Mendoza-Sassi RA, Klassen TP, Wainwright C. Nebulized hypertonic saline for acute bronchiolitis: a systematic review [erratum]. Pediatrics 2016;137(4):e20160017. [DOI: 10.1542/peds.2016-0017] 
CHARACTERISTICS OF STUDIES

Characteristics of included studies [ordered by study ID]

Al-Ansari 2010

\begin{tabular}{ll}
\hline Methods & Design: randomised, double-blind, parallel-group, controlled trial \\
\hline Participants & Setting: paediatric emergency facility in Qatar \\
Assessed for eligibility: 187 \\
Randomised: 115 hypertonic saline group ( $5 \%$ saline: $57 ; 3 \%$ saline: 58$) ; 56$ normal saline group \\
Completed: 115 hypertonic saline group; 56 normal saline group \\
Gender (male): $59.1 \%$ \\
Age (mean \pm SD): $3.8 \pm 2.8$ months in $3 \%$ saline group; $4.0 \pm 2.5$ months in $5 \%$ saline group; $3.3 \pm 2.4$ \\
months in normal saline group \\
Inclusion criteria: infants aged $\leq 18$ months, with a prodromal history of viral upper respiratory tract in- \\
fection, followed by wheezing or crackles, or both on auscultation and Wang clinical severity score $\geq 4$ \\
Exclusion criteria: born at $\leq 34$ weeks' gestation, previous history of wheezing, steroid use within $48 \mathrm{~h}$ \\
of presentation, obtundation and progressive respiratory failure requiring ICU admission, history of ap- \\
noea within 24 hours before presentation, SaO $\mathrm{O}_{2} \leq 85 \%$ on room air at the time of recruitment, history of \\
a diagnosis of chronic lung disease, congenital heart disease, or immunodeficiency
\end{tabular}

Interventions Intervention groups:

Group 1: nebulised $5 \%$ hypertonic saline $(5 \mathrm{~mL})$ plus $1.5 \mathrm{~mL}$ of epinephrine

Group 2: nebulised $3 \%$ hypertonic saline $(5 \mathrm{~mL})$ plus $1.5 \mathrm{~mL}$ of epinephrine

Control group: nebulised $0.9 \%$ normal saline $(5 \mathrm{~mL})$ plus $1.5 \mathrm{~mL}$ of epinephrine

Treatment was given every 4 hours, until the patient was ready for discharge. Nebulised medications were delivered through a tight-fitting face mask by pressurised oxygen with the flow meter set at $10 \mathrm{~L} /$ $\min$.

\begin{tabular}{ll}
\hline - Watcomes & - Oxygen saturation \\
- Length of stay \\
- Need for ICU admission \\
- Rate of re-admission \\
- Adverse events
\end{tabular}

Notes Virological identification not available

\section{Risk of bias}

\begin{tabular}{lll}
\hline Bias & Authors' judgement & Support for judgement \\
\hline $\begin{array}{l}\text { Random sequence genera- } \\
\text { tion (selection bias) }\end{array}$ & Low risk & Computer-based randomisation program \\
\hline $\begin{array}{l}\text { Allocation concealment } \\
\text { (selection bias) }\end{array}$ & Low risk & Sequentially numbered and sealed envelopes \\
\hline $\begin{array}{l}\text { Blinding (performance } \\
\text { bias and detection bias) }\end{array}$ & Low risk & Double-blind \\
$\begin{array}{l}\text { All outcomes } \\
\begin{array}{l}\text { Incomplete outcome data } \\
\text { (attrition bias) } \\
\text { All outcomes }\end{array}\end{array}$ & Low risk & $\begin{array}{l}16(9.3 \%) \text { withdrawals after randomisation; baseline characteristics between } \\
\text { treatment groups were balanced. }\end{array}$ \\
\hline \hline
\end{tabular}


Al-Ansari 2010 (Continued)
Selective reporting (re-
Low risk
All predefined outcomes reported. porting bias)

Other bias

Low risk

No other bias found.

Angoulvant 2017

\begin{tabular}{ll}
\hline Methods & Design: randomised, double-blind, parallel-group, controlled trial \\
\hline Participants & Setting: 24 paediatric emergency departments in France \\
Assessed for eligibility: 2445 \\
Randomised: 387 hypertonic saline group; 390 normal saline group \\
Completed: 385 hypertonic saline group; 387 normal saline group \\
Gender (male): $60.2 \%$ \\
Age: median (interquartile range): 3 (2 to 5) months in hypertonic saline group; 3 ( 2 to 5) months in nor- \\
mal saline group \\
Inclusion criteria: infants aged 6 weeks to 12 months with first episode of moderate to severe bronchi- \\
olitis defined as viral upper respiratory tract infection plus wheezing or crackles, or both on chest aus- \\
cultation with respiratory distress \\
Exclusion criteria: premature birth (birth before 37 weeks of gestation), immunologic, cardiac or chron- \\
ic pulmonary disease, bone malformation of the chest, previous use of nebulised hypertonic saline, in- \\
ability to communicate with the family (a language barrier or lack of telephone for contact), need of ad- \\
mission to a paediatric ICU
\end{tabular}

Interventions
Intervention groups: nebulised $3 \%$ hypertonic saline $(4 \mathrm{~mL})$
Control groups: nebulised $0.9 \%$ normal saline $(4 \mathrm{~mL})$
Study medication was given at 0 and 30 min using a jet nebuliser through a firmly applied face mask
with an oxygen flow rate of $6 \mathrm{~L} / \mathrm{min}$.

\begin{tabular}{ll}
\hline - Hutcomes & Hospital admission up to 24 hours after enrolment \\
- Admission within 28 days \\
- Changes in RDAl score \\
- Dength of hospital stay for hospitalised infants \\
- Adverse events
\end{tabular}

Notes $\quad$ RSV positive: $84.5 \%$ in hypertonic saline group; $88.2 \%$ in control group

\section{Risk of bias}

\begin{tabular}{lll}
\hline Bias & Authors' judgement & Support for judgement \\
\hline $\begin{array}{l}\text { Random sequence genera- } \\
\text { tion (selection bias) }\end{array}$ & Low risk & $\begin{array}{l}\text { Computer-generated random allocation sequence using a 1:1 ratio and per- } \\
\text { mutation } \\
\text { blocks with a block size of 4, stratified according to centre }\end{array}$ \\
\hline $\begin{array}{l}\text { Allocation concealment } \\
\text { (selection bias) }\end{array}$ & Low risk & $\begin{array}{l}\text { The investigational pharmacy prepared the study drugs in sequentially num- } \\
\text { bered and visually identical packets. Randomisation codes were kept secure } \\
\text { until data entry was complete. }\end{array}$ \\
\hline $\begin{array}{l}\text { Blinding (performance } \\
\text { bias and detection bias) }\end{array}$ & Low risk & Double-blinded \\
\hline
\end{tabular}


Angoulvant 2017 (Continued)

All outcomes

\begin{tabular}{|c|c|c|}
\hline $\begin{array}{l}\text { Incomplete outcome data } \\
\text { (attrition bias) }\end{array}$ & Low risk & $\begin{array}{l}\text { Hospitalisation data were not available for } 5 \text { infants ( } 2 \text { in hypertonic saline } \\
\text { group and } 3 \text { in normal saline group). }\end{array}$ \\
\hline
\end{tabular}

All outcomes

group and 3 in normal saline group).

Selective reporting (re- Low risk $\quad$ All predefined outcomes reported.
porting bias)

porting bias)

Other bias Low risk No other bias found.

\section{Anil 2010}

\begin{tabular}{ll}
\hline Methods & Design: randomised, double-blind, parallel-group, controlled trial \\
\hline Participants & Setting: emergency department of a teaching hospital in Turkey \\
Assessed for eligibility: 190 \\
Randomised: 75 hypertonic saline group; 111 normal saline group \\
Completed: 75 hypertonic saline group; 111 normal saline group \\
Gender (male): $64.5 \%$ \\
Age (mean \pm SD): $9.5 \pm 5.3$ months (range 1.5 to 24 months) \\
Inclusion criteria: infants with diagnosis of bronchiolitis requiring a history of upper respiratory infec- \\
tion and the presence of bilateral wheezing or crackles, or both on chest auscultation, plus clinical \\
severity score between 1 and 9 \\
Exclusion criteria: prematurity, any underlying disease (e.g. cystic fibrosis, bronchopulmonary dyspla- \\
sia, and cardiac or renal disease), prior history of wheezing, atopic dermatitis, allergic rhinitis or asth- \\
ma, SaO ${ }_{2}<85 \%$ on room air, clinical severity score $>9$, obtunded consciousness, progressive respirato- \\
ry failure requiring mechanical ventilation, previous treatment with bronchodilators, and any steroid \\
therapy within 2 weeks
\end{tabular}

Interventions

Intervention groups:

Group 1: nebulised 3\% hypertonic saline $(4 \mathrm{~mL})$ plus $1.5 \mathrm{mg}$ epinephrine

Group 2: nebulised 3\% hypertonic saline $(4 \mathrm{~mL})$ plus $2.5 \mathrm{mg}$ salbutamol

Control groups:

Group 3: nebulised $0.9 \%$ normal saline $(4 \mathrm{~mL})$ plus $1.5 \mathrm{mg}$ epinephrine

Group 4: nebulised $0.9 \%$ normal saline $(4 \mathrm{~mL})$ plus $2.5 \mathrm{mg}$ salbutamol

Group 5: nebulised $0.9 \%$ normal saline $(4 \mathrm{~mL})$ alone

The study drug was administered at 0 and 30 min by Medic-Aid Sidestream nebuliser (Medic-Aid Ltd., West Sussex, UK) using a face mask with continuous flow of $100 \%$ oxygen at $6 \mathrm{~L} / \mathrm{min}$.

\begin{tabular}{ll}
\hline Outcomes & - Wang clinical severity score \\
- Oxygen saturation \\
- Heart rate \\
- Rate of hospitalisation \\
- Rdve of re-admission \\
\end{tabular}

Notes Virological identification not available.

\section{Risk of bias}


Anil 2010 (Continued)

Random sequence genera- Low risk $\quad$ Computer-based randomisation program
tion (selection bias)

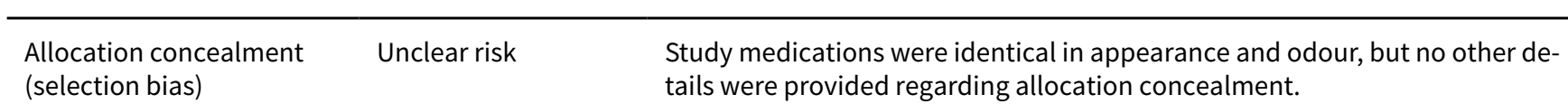

Blinding (performance Double-blind
bias and detection bias)
All outcomes

Incomplete outcome data Low risk No withdrawals reported.
(attrition bias)

All outcomes

\begin{tabular}{lll}
\hline $\begin{array}{l}\text { Selective reporting (re- } \\
\text { porting bias) }\end{array}$ & Low risk & All predefined outcomes reported. \\
\hline Other bias & Low risk & No other bias found. \\
\hline
\end{tabular}

Everard 2014

\begin{tabular}{ll}
\hline Methods & Design: multicentre, parallel-group, open, randomised controlled trial \\
\hline Participants & Setting: assessment units and paediatric wards of 10 participating centres in England and Wales \\
Assessed for eligibility: 772 \\
Randomised: 158 hypertonic saline group ( $3 \%$ saline); 159 standard care group \\
Completed: 141 hypertonic saline group; 149 standard care group \\
Gender (male): $54.5 \%$ \\
Age (mean \pm SD): $3.3 \pm 2.6$ months in hypertonic saline group; $3.4 \pm 2.8$ months in standard care group \\
Inclusion criteria: infants < 12 months with diagnosis of bronchiolitis defined as an apparent viral respi- \\
ratory tract infection associated with airways obstruction manifest by hyperinflation, tachypnoea and \\
subcostal recession with widespread crepitations on auscultation, needing supplementary oxygen for \\
SaO ${ }_{2}$ of < $92 \%$ in air \\
Exclusion criteria: history of wheezy bronchitis or asthma, gastro-oesophageal reflux, previous lower \\
respiratory tract infections, risk factors for severe disease, carers lacking fluent English in the absence \\
of translator service, and requiring admission to high dependency or intensive care units at presenta- \\
tion
\end{tabular}

Intervention group: $4 \mathrm{~mL} 3 \%$ saline + standard care
Control group: standard care
Hypertonic saline given every $6 \mathrm{~h}$, administered via PARI Sprint nebuliser with appropriate face mask,
until primary outcome achieved.

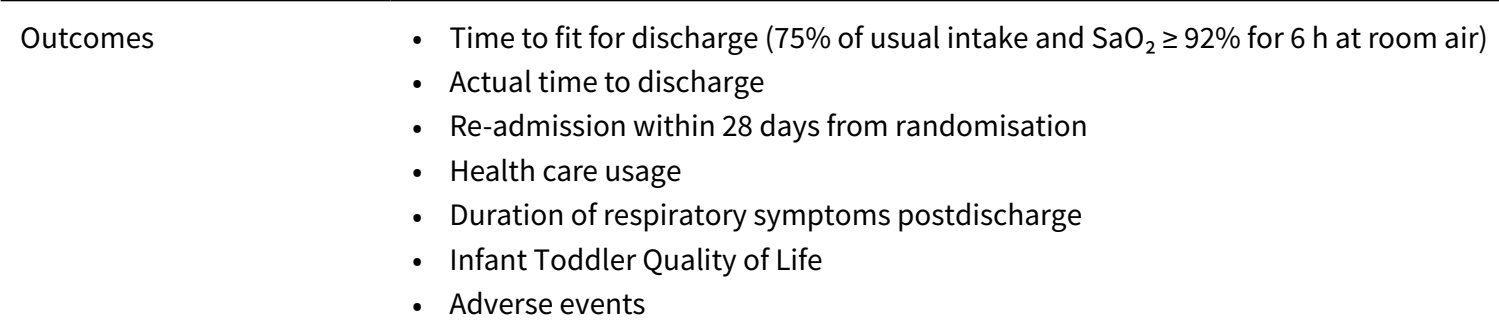


Everard 2014 (Continued)

Risk of bias

\begin{tabular}{lll}
\hline Bias & Authors' judgement & Support for judgement \\
\hline $\begin{array}{l}\text { Random sequence genera- } \\
\text { tion (selection bias) }\end{array}$ & Low risk & $\begin{array}{l}\text { Computer-generated randomisation in blocks of size two, four, and six, strati- } \\
\text { fied by hospital }\end{array}$ \\
\hline $\begin{array}{l}\text { Allocation concealment } \\
\text { (selection bias) }\end{array}$ & Low risk & Centralised web-based randomisation system \\
\hline $\begin{array}{l}\text { Blinding (performance } \\
\text { bias and detection bias) } \\
\text { All outcomes }\end{array}$ & High risk & Open study \\
\hline $\begin{array}{l}\text { Incomplete outcome data } \\
\text { (attrition bias) }\end{array}$ & Low risk & $\begin{array}{l}27 \text { (8.5\%) withdrawals after randomisation (17 hypertonic saline group, 10 } \\
\text { control group); baseline characteristics between treatment groups were bal- } \\
\text { anced. }\end{array}$ \\
\hline $\begin{array}{l}\text { Selective reporting (re- } \\
\text { porting bias) }\end{array}$ & Low risk & All predefined outcomes reported. \\
\hline \begin{tabular}{l} 
Other bias \\
\hline
\end{tabular} & Low risk & No other bias found. \\
\hline
\end{tabular}

Flores 2016

Methods Design: randomised, double-blind, parallel-group, controlled trial

Participants

Setting: paediatric ward of a general urban hospital in Portugal

Assessed for eligibility: not stated

Randomised: 38 hypertonic saline group (3\% saline); 40 normal saline group

Completed: 33 hypertonic saline group; 35 normal saline group

Gender (male): $52.9 \%$

Age (mean \pm SD): $3.3 \pm 2.4$ months hypertonic saline group; $3.8 \pm 2.5$ months normal saline group

Inclusion criteria: infants aged $<12$ months with acute bronchiolitis, defined as an apparent viral respiratory tract infection manifest by nasal discharge and wheezy cough, with presence of fine inspiratory crackles and/or high-pitched expiratory wheeze, even apnoea

Exclusion criteria: previous episodes of wheezing, personal history of prematurity (gestational age < 34 weeks), physician diagnosis of eczema, food allergy, or chronic (cardiac, respiratory, immunological, neurological, or metabolic) disease and high severity criteria (coma, respiratory rate $>80$ breaths/ minute, $\mathrm{SaO}_{2}<88 \%$ on room air or need for assisted ventilation)

Interventions

Intervention group: nebulised 3\% hypertonic saline $(3 \mathrm{~mL})$ plus $0.25 \mathrm{~mL}(1.25 \mathrm{mg})$ salbutamol

Control group: nebulised $0.9 \%$ normal saline $(3 \mathrm{~mL})$ plus $0.25 \mathrm{~mL}(1.25 \mathrm{mg})$ salbutamol

Treatment was given every $6 \mathrm{~h}$ until discharge. All inhaled therapies were delivered through a tight-fitting face mask from an oxygen-driven nebuliser (Cirrus 2 Nebuliser, Wokingham, Berkshire, UK), connected to a source of pressurised oxygen from the wall, set to a flow rate of $6 \mathrm{~L} / \mathrm{min}$.

- Length of hospital stay (fit to discharge and actual discharge)
- Wang severity score
- Need for supplemental oxygen and tube feeding and their duration
- Need for other treatments (further doses of salbutamol, nebulised epinephrine, systemic corticos-
teroids, antibiotics, or diuretics)


Flores 2016 (Continued)

- Adverse events

Notes $\quad$ RSV positive: $87.9 \%$ in hypertonic saline group; $82.9 \%$ in normal saline group

\section{Risk of bias}

\begin{tabular}{lll}
\hline Bias & Authors' judgement & Support for judgement \\
\hline $\begin{array}{l}\text { Random sequence genera- } \\
\text { tion (selection bias) }\end{array}$ & Low risk & Computer-generated randomisation \\
\hline $\begin{array}{l}\text { Allocation concealment } \\
\text { (selection bias) }\end{array}$ & Low risk & $\begin{array}{l}\text { Both solutions were similar in appearance and smell, were stored in identical } \\
\text { syringes, and were labelled only by a code number. Randomisation list was } \\
\text { concealed by the pharmacy. }\end{array}$ \\
\hline $\begin{array}{l}\text { Blinding (performance } \\
\text { bias and detection bias) }\end{array}$ & Low risk & Double-blind \\
$\begin{array}{l}\text { All outcomes } \\
\begin{array}{l}\text { Incomplete outcome data } \\
\text { (attrition bias) } \\
\text { All outcomes }\end{array}\end{array}$ & Low risk & $\begin{array}{l}10 \text { (12.8\%) withdrawals after randomisation (5 hypertonic saline group, 5 con- } \\
\text { trol group); baseline characteristics between treatment groups were balanced. }\end{array}$ \\
\hline $\begin{array}{l}\text { Selective reporting (re- } \\
\text { porting bias) }\end{array}$ & Low risk & All predefined outcomes reported. \\
\hline \begin{tabular}{l} 
Other bias \\
\hline
\end{tabular} & Low risk & No other bias found. \\
\hline
\end{tabular}

Florin 2014

\begin{tabular}{|c|c|}
\hline Methods & Design: randomised, double-blind, parallel-group, controlled trial \\
\hline \multirow[t]{8}{*}{ Participants } & Setting: urban paediatric emergency department in USA \\
\hline & Assessed for eligibility: 2256 \\
\hline & Randomised: 31 hypertonic saline group (3\% saline); 31 normal saline group \\
\hline & Completed: 31 hypertonic saline group; 31 normal saline group \\
\hline & Gender (male): $45.2 \%$ \\
\hline & Age (mean $\pm S D): 7.2 \pm 5.1$ months in hypertonic saline group; $6.1 \pm 3.6$ months in normal saline group \\
\hline & $\begin{array}{l}\text { Inclusion criteria: children aged } 2 \text { months up to } 24 \text { months presenting to the emergency department } \\
\text { with acute bronchiolitis, defined as a first episode of wheezing associated with signs and symptoms of } \\
\text { respiratory distress and upper respiratory infection, with RDAl score of } 4 \text { to } 15 \text { (moderate to severe) }\end{array}$ \\
\hline & $\begin{array}{l}\text { Exclusion criteria: infants with a history of wheezing or asthma, bronchodilator therapy prior to the cur- } \\
\text { rent illness, chronic lung or heart disease, critical illness, inability to receive nebulised medications, } \\
\text { and infants with non-English-speaking guardians }\end{array}$ \\
\hline \multirow[t]{3}{*}{ Interventions } & Intervention group: nebulised $3 \%$ hypertonic saline $(4 \mathrm{~mL})$ \\
\hline & Control group: nebulised $0.9 \%$ normal saline $(4 \mathrm{~mL})$ \\
\hline & $\begin{array}{l}\text { Treatment delivered using a jet nebuliser with an oxygen flow rate of } 8 \mathrm{~L} / \mathrm{min} \text {. Study medication was } \\
\text { given within } 90 \text { minutes after albuterol administration. }\end{array}$ \\
\hline \multirow[t]{3}{*}{ Outcomes } & - Respiratory assessment change score (RACS) \\
\hline & - Heart rate \\
\hline & - Respiratory rate \\
\hline
\end{tabular}


Florin 2014 (Continued)

- Oxygen saturation

- Rate of hospitalisation

- Physician clinical impression (i.e. overall rating of clinical severity, categorised as mild, moderate, or severe)

- Parental perception of improvement in breathing and feeding (i.e. improved, worse, or unchanged)

- Adverse events

Notes Virological identification not available.

\section{Risk of bias}

\begin{tabular}{lll}
\hline Bias & Authors' judgement & Support for judgement \\
\hline $\begin{array}{l}\text { Random sequence genera- } \\
\text { tion (selection bias) }\end{array}$ & Low risk & Computer-generated random permuted block randomisation \\
\hline $\begin{array}{l}\text { Allocation concealment } \\
\text { (selection bias) }\end{array}$ & Low risk & $\begin{array}{l}\text { The investigational pharmacy prepared the study medications, which were } \\
\text { stored in sequentially numbered envelopes with blinded syringes labelled only } \\
\text { with the study number. }\end{array}$ \\
\hline $\begin{array}{l}\text { Blinding (performance } \\
\text { bias and detection bias) }\end{array}$ & Low risk & Double-blind \\
\hline $\begin{array}{l}\text { All outcomes } \\
\begin{array}{l}\text { Incomplete outcome data } \\
\text { All outcomes }\end{array}\end{array}$ & Low risk & No withdrawals reported. \\
\hline $\begin{array}{l}\text { Selective reporting (re- } \\
\text { porting bias) }\end{array}$ & Low risk & All predefined outcomes reported. \\
\hline \begin{tabular}{l} 
Other bias \\
\hline
\end{tabular} & Low risk & No other bias found. \\
\hline
\end{tabular}

Grewal 2009

\begin{tabular}{ll}
\hline Methods & Design: randomised, double-blind, parallel-group, controlled trial \\
\hline Participants & Setting: emergency department of a children's hospital in Canada \\
Assessed for eligibility: not stated & Randomised: 24 hypertonic saline group; 24 normal saline group \\
Completed: 23 hypertonic saline group; 23 normal saline group \\
Gender (male): $60.9 \%$ \\
Age (mean \pm SD): $5.6 \pm 4.0$ months in hypertonic saline group; $4.4 \pm 3.4$ months in normal saline group \\
Inclusion criteria: infants aged 6 weeks to 12 months presenting with a first episode of wheezing and \\
clinical symptoms of a viral respiratory infection, plus an initial SaO ${ }_{2}$ of $85 \%$ or more but $96 \%$ or less, \\
and RDAl score $\geq 4$ \\
Exclusion criteria: pre-existing cardiac or pulmonary disease, previous diagnosis of asthma by a physi- \\
cian, any previous use of bronchodilators (except for treatment of the current illness), severe disease \\
requiring resuscitation room care, inability to take medication using a nebuliser, inability to obtain in- \\
formed consent secondary to a language barrier, or no phone access for follow-up
\end{tabular}

Interventions

Intervention group: nebulised $3 \%$ hypertonic saline $(2.5 \mathrm{~mL})$ plus $0.5 \mathrm{~mL} 2.25 \%$ racaemic epinephrine Control group: nebulised $0.9 \%$ normal saline $(2.5 \mathrm{~mL})$ plus $0.5 \mathrm{~mL} 2.25 \%$ racaemic epinephrine Both groups received inhalation solutions at 0 minutes. 
Grewal 2009 (Continued)

Each treatment was given by nebuliser with continuous flow of oxygen at $6 \mathrm{~L} / \mathrm{min}$. 2 doses of the study drug were available for each infant such that, if the physician felt that a second dose of racaemic epinephrine was needed during the 120-minute study period, the infant received the same drug combination again.

\begin{tabular}{|c|c|c|}
\hline Outcomes & \multicolumn{2}{|c|}{$\begin{array}{l}\text { - Respiratory assessment change score } \\
\text { - Oxygen saturation } \\
\text { - Rate of hospitalisation } \\
\text { - Rate of re-admission } \\
\text { - Adverse events }\end{array}$} \\
\hline Notes & \multicolumn{2}{|c|}{ RSV positive: $82.6 \%$ in hypertonic saline group; $81.8 \%$ in normal saline group } \\
\hline \multicolumn{3}{|l|}{ Risk of bias } \\
\hline Bias & Authors' judgement & Support for judgement \\
\hline $\begin{array}{l}\text { Random sequence genera- } \\
\text { tion (selection bias) }\end{array}$ & Low risk & Website randomisation scheme \\
\hline $\begin{array}{l}\text { Allocation concealment } \\
\text { (selection bias) }\end{array}$ & Low risk & $\begin{array}{l}\text { The solutions prepared by the hospital pharmacy were similar in appearance } \\
\text { and smell, stored in identical syringes, labelled only by a code number, and } \\
\text { placed in the research cupboard within the emergency department. }\end{array}$ \\
\hline $\begin{array}{l}\text { Blinding (performance } \\
\text { bias and detection bias) } \\
\text { All outcomes }\end{array}$ & Low risk & Double-blind \\
\hline $\begin{array}{l}\text { Incomplete outcome data } \\
\text { (attrition bias) } \\
\text { All outcomes }\end{array}$ & Low risk & 2 (4.1\%) withdrawals (1 hypertonic saline group; 1 normal saline group) \\
\hline $\begin{array}{l}\text { Selective reporting (re- } \\
\text { porting bias) }\end{array}$ & Low risk & All predefined outcomes reported. \\
\hline Other bias & Low risk & No other bias found. \\
\hline
\end{tabular}

Ipek 2011

Methods Design: quasi-randomised, double-blind, parallel-group, controlled trial

Participants

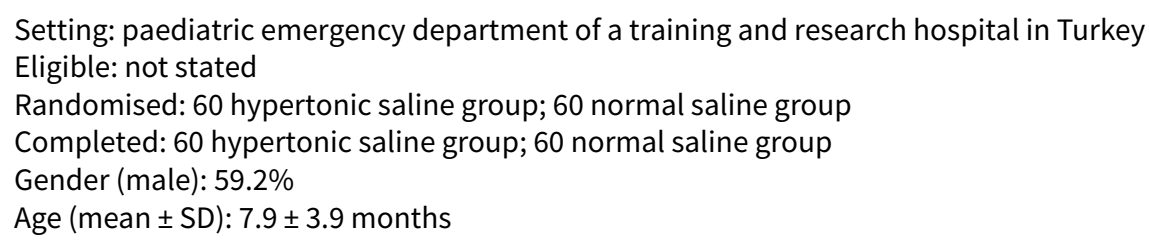

Exclusion criteria: infants with clinical severity score $<4$ or $>8, \mathrm{SaO}_{2}<85 \%$ on room air, chronic cardiac illness, premature birth, birth weight $<2500 \mathrm{~g}$, history of recurrent wheezing episodes, proven immune deficiency, severe neurological disease, age $<1$ month or $>2$ years, consolidation or atelectasis on a chest roentgenogram 
Ipek 2011 (Continued)

Interventions
Group 1: nebulised 3\% hypertonic saline $(4 \mathrm{~mL})$ plus salbutamol $0.15 \mathrm{mg} / \mathrm{kg}$
Group 2: nebulised 3\% hypertonic saline $(4 \mathrm{~mL})$ alone
Control groups:
Group 1: nebulised $0.9 \%$ hypertonic saline $(4 \mathrm{~mL})$ plus salbutamol $0.15 \mathrm{mg} / \mathrm{kg}$
Group 2: nebulised $0.9 \%$ hypertonic saline $(4 \mathrm{~mL})$ alone

The treatment was given every 20 min until 3 doses had been administered (0, 20, and $40 \mathrm{~min}$ ). All inhaled therapies were delivered via a compressor nebuliser through a face mask with continued flow of oxygen at 4 to 5 L/min (Mini Compressor Nebulizer, CN-02WD, Ace-Tec Co., Ltd., Guangdong, China).

\begin{tabular}{ll}
\hline Outcomes & Wang clinical severity score \\
- Oxygen saturation \\
- Respiratory rate \\
- Heart rate \\
- Corticosteroid need \\
- Rate of hospitalisation \\
\hline
\end{tabular}

\begin{tabular}{ll}
\hline Notes $\quad$ Virological identification not available. \\
\hline
\end{tabular}

\section{Risk of bias}

\begin{tabular}{|c|c|c|}
\hline Bias & Authors' judgement & Support for judgement \\
\hline $\begin{array}{l}\text { Random sequence genera- } \\
\text { tion (selection bias) }\end{array}$ & High risk & $\begin{array}{l}\text { Infants were assigned to } 1 \text { of } 4 \text { groups according to the consecutive order of } \\
\text { their admission to the short-stay unit. }\end{array}$ \\
\hline $\begin{array}{l}\text { Allocation concealment } \\
\text { (selection bias) }\end{array}$ & High risk & As stated above \\
\hline $\begin{array}{l}\text { Blinding (performance } \\
\text { bias and detection bias) } \\
\text { All outcomes }\end{array}$ & Unclear risk & The trial was stated to be double-blind, but no details were provided. \\
\hline $\begin{array}{l}\text { Incomplete outcome data } \\
\text { (attrition bias) } \\
\text { All outcomes }\end{array}$ & Low risk & No withdrawals reported. \\
\hline $\begin{array}{l}\text { Selective reporting (re- } \\
\text { porting bias) }\end{array}$ & Low risk & All predefined outcomes reported. \\
\hline Other bias & Low risk & No other bias found. \\
\hline
\end{tabular}

Jacobs 2014

\begin{tabular}{ll} 
Methods & Design: randomised, double-blind, parallel-group, controlled trial \\
\hline Participants & Setting: emergency department of an urban tertiary care centre in the USA \\
& Assessed for eligibility: 128 \\
Randomised: 52 hypertonic saline group; 49 normal saline group \\
Completed: 52 hypertonic saline group; 49 normal saline group \\
Gender (male): $63.3 \%$ \\
Age (mean \pm SD): $6.0 \pm 3.9$ months in hypertonic saline group; $5.6 \pm 3.3$ months in normal saline group
\end{tabular}


Jacobs 2014 (Continued)

Inclusion criteria: infants aged 6 weeks to 18 months presenting to the emergency department with acute bronchiolitis, defined as viral respiratory illness and first episode of wheeze, and a modified Wang clinical severity score of $\geq 4$

Exclusion criteria: previous history of wheezing, any use of bronchodilators within 2 hours of presentation, gestational age $\leq 34$ weeks, history of congenital heart disease or chronic pulmonary or chronic renal disease, $\mathrm{SaO}_{2} \leq 85 \%$ at the time of recruitment, severe disease requiring ICU admission, or inability to obtain informed consent

Interventions
Control group: nebulised $0.9 \%$ hypertonic saline $(3 \mathrm{~mL})$ plus $2.25 \%$ racemic epinephrine $(0.5 \mathrm{~mL})$
The medication was given via a nebuliser driven by oxygen flow at $6 \mathrm{~L} / \mathrm{min}$ after initial screening and
assessment. If admitted, the infant continued to receive the same designated medication every $6 \mathrm{~h}$ un-
til discharge or $24 \mathrm{~h}$ after admission.

\begin{tabular}{ll}
\hline Outcomes & Modified Wang clinical severity score \\
- Rate of hospitalisation \\
- Discharge rate at $23 \mathrm{~h}$ (observation status) \\
- Length of hospital stay \\
- Adverse events
\end{tabular}

Notes $\quad$ RSV positive: $68 \%$ in hypertonic saline group; $50 \%$ in control group

\section{Risk of bias}

\begin{tabular}{lll}
\hline Bias & Authors' judgement & Support for judgement \\
\hline $\begin{array}{l}\text { Random sequence genera- } \\
\text { tion (selection bias) }\end{array}$ & Unclear risk & $\begin{array}{l}\text { Randomisation in blocks of 10, but it is unclear how to choose blocks at ran- } \\
\text { dom to create the allocation sequence. }\end{array}$ \\
\hline $\begin{array}{l}\text { Allocation concealment } \\
\text { (selection bias) }\end{array}$ & Low risk & $\begin{array}{l}\text { Sequentially numbered, concealed envelopes containing either 7\% or 0.9\% } \\
\text { saline solution }\end{array}$ \\
\hline $\begin{array}{l}\text { Blinding (performance } \\
\text { bias and detection bias) } \\
\text { All outcomes }\end{array}$ & Low risk & Double-blind \\
\hline $\begin{array}{l}\text { Incomplete outcome data } \\
\text { (attrition bias) } \\
\text { All outcomes }\end{array}$ & Low risk & No withdrawals reported. \\
\hline $\begin{array}{l}\text { Selective reporting (re- } \\
\text { porting bias) }\end{array}$ & Low risk & All predefined outcomes reported. \\
\hline \begin{tabular}{l} 
Other bias \\
\hline
\end{tabular} & Low risk & No other bias found. \\
\hline
\end{tabular}

Khanal 2015

\begin{tabular}{ll}
\hline Methods & Design: randomised, double-blind, parallel-group, controlled trial \\
\hline Participants & Setting: emergency and outpatient departments of a children's hospital in Nepal \\
& Assessed for eligibility: 146 \\
Randomised: 50 hypertonic saline group ( $3 \%$ saline); 50 normal saline group \\
Completed: 49 hypertonic saline group; 50 normal saline group
\end{tabular}


Khanal 2015 (Continued)

Gender (male): $48 \%$

Age (mean $\pm \mathrm{SD}$ ): $9.8 \pm 5.0$ months in hypertonic saline group; $9.5 \pm 4.2$ months in normal saline group

Inclusion criteria: infants aged 6 weeks to 2 years with acute bronchiolitis defined as the first episode of acute wheezing, starting as a viral upper respiratory infection (coryza, cough or fever), with Wang clinical severity score between 1 and 9

Exclusion criteria: any underlying disease (e.g. cystic fibrosis, bronchopulmonary dysplasia, and cardiac or renal disease), prior history of wheezing, diagnosed case of asthma, $\mathrm{SaO}_{2}<85 \%$ on room air, clinical severity score $>9$, progressive respiratory distress requiring mechanical ventilation, previous treatment with bronchodilators within last $4 \mathrm{~h}$, and any steroid therapy within $48 \mathrm{~h}$

Interventions Intervention group: nebulised $3 \%$ hypertonic saline $(4 \mathrm{~mL})$ plus L-epinephrine (1.5 mg)

Control group: nebulised $0.9 \%$ normal saline $(4 \mathrm{~mL})$ plus L-epinephrine $(1.5 \mathrm{mg})$

The study drug was administered at 0 and 30 min by a jet nebuliser using a face mask.

\begin{tabular}{ll}
\hline Outcomes & Wang clinical severity score \\
- Oxygen saturation & Respiratory rate \\
- Heart rate \\
- Discharge readiness at the end of $2 \mathrm{~h}$ of observation \\
- Re-admission rate within $24 \mathrm{~h}$ following discharge \\
- Adverse events
\end{tabular}

Notes Virological identification not available.

\section{Risk of bias}

\begin{tabular}{|c|c|c|}
\hline Bias & Authors' judgement & Support for judgement \\
\hline $\begin{array}{l}\text { Random sequence genera- } \\
\text { tion (selection bias) }\end{array}$ & Low risk & Computer-generated block randomisation (in blocks of 10) \\
\hline $\begin{array}{l}\text { Allocation concealment } \\
\text { (selection bias) }\end{array}$ & Low risk & $\begin{array}{l}\text { Study solutions were labelled with the codes and wrapped in an envelope } \\
\text { bearing the respective codes. Study solutions were identical in appearance } \\
\text { and odour. }\end{array}$ \\
\hline $\begin{array}{l}\text { Blinding (performance } \\
\text { bias and detection bias) } \\
\text { All outcomes }\end{array}$ & Low risk & Double-blind \\
\hline $\begin{array}{l}\text { Incomplete outcome data } \\
\text { (attrition bias) } \\
\text { All outcomes }\end{array}$ & Low risk & $1(1 \%)$ withdrawal after randomisation in hypertonic saline group \\
\hline $\begin{array}{l}\text { Selective reporting (re- } \\
\text { porting bias) }\end{array}$ & Low risk & All predefined outcomes reported. \\
\hline Other bias & Low risk & No other bias found. \\
\hline
\end{tabular}

Methods Design: randomised, double-blind, parallel-group, controlled trial


Kuzik 2007 (Continued)

Participants
Setting: inpatient wards of 3 regional tertiary care hospitals, 1 in United Arab Emirates and 2 in Canada Eligible: not stated

Randomised: 47 hypertonic saline group; 49 normal saline group

Completed: 45 hypertonic saline group; 46 normal saline group

Gender (male): $59.4 \%$

Age (mean $\pm \mathrm{SD}$ ): $4.7 \pm 4.2$ months (range 10 days to 18 months)

Inclusion criteria: infants with diagnosis of moderately severe bronchiolitis requiring a history of a preceding viral upper respiratory infection, the presence of wheezing or crackles on chest auscultation, plus either an $\mathrm{SaO}_{2}<94 \%$ in room air or RDAl score $\geq 4$

Exclusion criteria: previous episode of wheezing, chronic cardiopulmonary disease or immunodeficiency, critical illness at presentation requiring admission to intensive care, the use of nebulised hypertonic saline within the previous $12 \mathrm{~h}$, or premature birth (gestational age $\leq 34$ weeks)
Intervention group: nebulised $3 \%$ hypertonic saline $(4 \mathrm{~mL})$

Control group: nebulised $0.9 \%$ normal saline $(4 \mathrm{~mL})$

The treatment was given every $2 \mathrm{~h}$ for 3 doses, followed by every $4 \mathrm{~h}$ for 5 doses, followed by every $6 \mathrm{~h}$ until discharge. All inhaled therapies were delivered to a settled infant from a standard oxygen-driven hospital nebuliser through a tight-fitting face mask or head box, whichever the infant tolerated better.

\begin{tabular}{ll}
\hline Outcomes & - Length of hospital stay \\
- Treatments received during the study \\
- Adverse events
\end{tabular}

Notes $\quad$ RSV positive: $62 \%$ in hypertonic saline group; $75 \%$ in normal saline group

\section{Risk of bias}

\begin{tabular}{|c|c|c|}
\hline Bias & Authors' judgement & Support for judgement \\
\hline $\begin{array}{l}\text { Random sequence genera- } \\
\text { tion (selection bias) }\end{array}$ & Low risk & Computer-based randomisation program \\
\hline $\begin{array}{l}\text { Allocation concealment } \\
\text { (selection bias) }\end{array}$ & Low risk & $\begin{array}{l}\text { Study solutions were prepared by a research pharmacist and were identical in } \\
\text { appearance and odour. The identity of the study solutions was blinded to all } \\
\text { participants, care providers, and investigators. }\end{array}$ \\
\hline $\begin{array}{l}\text { Blinding (performance } \\
\text { bias and detection bias) } \\
\text { All outcomes }\end{array}$ & Low risk & Double-blind \\
\hline $\begin{array}{l}\text { Incomplete outcome data } \\
\text { (attrition bias) } \\
\text { All outcomes }\end{array}$ & Low risk & $\begin{array}{l}5(5.2 \%) \text { withdrawals after randomisation ( } 2 \text { hypertonic saline group; } 3 \text { normal } \\
\text { saline group); intention-to-treat analysis used. }\end{array}$ \\
\hline $\begin{array}{l}\text { Selective reporting (re- } \\
\text { porting bias) }\end{array}$ & Low risk & All predefined outcomes reported. \\
\hline Other bias & Low risk & No other bias found. \\
\hline
\end{tabular}

Köse 2016

Methods Design: randomised, double-blind, parallel-group, controlled trial 
Köse 2016 (Continued)

Participants

Setting: inpatient wards of a children's hospital in Turkey

Assessed for eligibility: not stated

Randomised: 35 (3\% saline group); 34 (7\% saline group); 35 (normal saline group)

Completed: 35 (3\% saline group); 32 (7\% saline group); 35 (normal saline group)

Gender (male): $40.3 \%$

Age: median (min-max): 7.6 ( 2 to 23 ) months in 3\% saline group; 7.7 (1 to 24 ) months in $7 \%$ saline group; 7.6 ( 1 to 18 ) months in $0.9 \%$ saline group

Inclusion criteria: infants aged 1 to 24 months with clinical diagnosis of bronchiolitis, defined as the first wheezing episode followed by a viral upper respiratory infection, with crackles on auscultation, and Wang clinical severity score $\geq 4$

Exclusion criteria: infants with clinical severity score $<4, \mathrm{SaO}_{2}<80 \%$ in room air, chronic cardiopulmonary or neurological disease, premature birth, birth weight $<2500 \mathrm{~g}$, history of recurrent wheezing episodes, proven immune deficiency, age $<1$ month or $>2$ years, proven or suspected acute bacterial infection, previous treatment with bronchodilators or corticosteroids, the presence of symptoms $>7$ days, consolidation or atelectasis on a chest roentgenogram

Interventions
Intervention groups:
Nebulised $3 \%$ hypertonic saline $(2.5 \mathrm{~mL})$ plus salbutamol $(0.15 \mathrm{mg} / \mathrm{kg})$
Nebulised $7 \%$ hypertonic saline $(2.5 \mathrm{~mL})$ plus salbutamol $(0.15 \mathrm{mg} / \mathrm{kg})$
Control group: nebulised $0.9 \%$ normal saline $(2.5 \mathrm{~mL})$ plus salbutamol $(0.15 \mathrm{mg} / \mathrm{kg})$
2 doses were given at 30 -minute interval, followed by every 6 h until discharge.

\begin{tabular}{ll}
\hline Outcomes & - Length of hospital stay \\
& $\cdot$ Wang severity score \\
& - Adverse events \\
\hline Notes & Virological identification not available.
\end{tabular}

\section{Risk of bias}

\begin{tabular}{lll}
\hline Bias & Authors' judgement & Support for judgement \\
\hline $\begin{array}{l}\text { Random sequence genera- } \\
\text { tion (selection bias) }\end{array}$ & Low risk & Computer-generated stratified randomisation \\
\hline $\begin{array}{l}\text { Allocation concealment } \\
\text { (selection bias) }\end{array}$ & Unclear risk & No details provided. \\
\hline $\begin{array}{l}\text { Blinding (performance } \\
\text { bias and detection bias) } \\
\text { All outcomes }\end{array}$ & Unclear risk & The trial was stated to be double-blind, but no details were provided. \\
\hline $\begin{array}{l}\text { Incomplete outcome data } \\
\text { (attrition bias) } \\
\text { All outcomes }\end{array}$ & Low risk & 2 (1.9\%) withdrawals after randomisation in 7\% saline group \\
\hline $\begin{array}{l}\text { Selective reporting (re- } \\
\text { porting bias) }\end{array}$ & Low risk & All predefined outcomes reported. \\
\hline \begin{tabular}{l} 
Other bias \\
\hline
\end{tabular} & Low risk & No other bias found. \\
\hline
\end{tabular}




\begin{tabular}{ll}
\hline Methods & Design: randomised, parallel-group, controlled trial \\
\hline Participants & Setting: outpatient department of a children's hospital in China \\
Assessed for eligibility: not stated \\
Randomised: 85 hypertonic saline groups ( $5 \%$ saline: $41 ; 3 \%$ saline: 44$) ; 44$ normal saline group \\
Completed: 82 hypertonic saline groups ( $5 \%$ saline: $40 ; 3 \%$ saline: 42 ); 42 normal saline group \\
Gender (male): $73.3 \%$ \\
Age: median (quartiles): 6.7 (3.1) months in $3 \%$ saline group; 6.7 (3.6) months in $5 \%$ saline group; 7.6 \\
(3.9) months in $0.9 \%$ saline group \\
Inclusion criteria: infants aged 2 months to 18 months with clinical diagnosis of acute bronchiolitis and \\
Wang clinical severity score $\geq 4$ \\
Exclusion criteria: severe bronchiolitis (respiratory rate $>80$ breaths per minute, SaO ${ }_{2}<85 \%$ on room \\
air or need for mechanical ventilation), immunological deficiency diseases, cardiac diseases, neurologi- \\
cal or metabolic diseases, chronic respiratory diseases, prematurity, and previous history of wheezing
\end{tabular}

\begin{tabular}{ll}
\hline Interventions & Intervention groups: \\
& Nebulised $3 \%$ hypertonic saline $(3 \mathrm{~mL})$ \\
& Nebulised $5 \%$ hypertonic saline $(3 \mathrm{~mL})$ \\
& Control group: nebulised $0.9 \%$ normal saline $(3 \mathrm{~mL})$ \\
& The study drug was administered by a jet nebuliser, twice daily for 3 days. \\
\hline Outcomes & - Wang clinical severity score \\
\hline Notes & Virological identification not available.
\end{tabular}

\section{Risk of bias}

\begin{tabular}{|c|c|c|}
\hline Bias & Authors' judgement & Support for judgement \\
\hline $\begin{array}{l}\text { Random sequence genera- } \\
\text { tion (selection bias) }\end{array}$ & Low risk & Random sequence generated using a random number table. \\
\hline $\begin{array}{l}\text { Allocation concealment } \\
\text { (selection bias) }\end{array}$ & Unclear risk & No details provided. \\
\hline $\begin{array}{l}\text { Blinding (performance } \\
\text { bias and detection bias) } \\
\text { All outcomes }\end{array}$ & Unclear risk & No details provided. \\
\hline $\begin{array}{l}\text { Incomplete outcome data } \\
\text { (attrition bias) } \\
\text { All outcomes }\end{array}$ & Low risk & $\begin{array}{l}5(3.8 \%) \text { withdrawals after randomisation ( } 15 \% \text { saline group, } 23 \% \text { saline } \\
\text { group, } 2 \text { normal saline group) }\end{array}$ \\
\hline $\begin{array}{l}\text { Selective reporting (re- } \\
\text { porting bias) }\end{array}$ & Low risk & All predefined outcomes reported. \\
\hline Other bias & Low risk & No other bias found. \\
\hline
\end{tabular}




\begin{tabular}{ll}
\hline Methods & Design: randomised, double-blind, parallel-group, controlled trial \\
\hline Participants & Setting: inpatient wards of a teaching hospital for children in China \\
& Eligible: not stated \\
& Randomised: 50 hypertonic saline group; 43 normal saline group \\
& Completed: 50 hypertonic saline group; 43 normal saline group \\
& Gender (male): $60.2 \%$ \\
& Age (mean \pm SD): $6.0 \pm 4.3$ months in hypertonic saline group; $5.6 \pm 4.5$ months in normal saline group \\
& Inclusion criteria: infants with a diagnosis of mild to moderately severe bronchiolitis \\
& Exclusion criteria: age $>24$ months, previous episode of wheezing, chronic cardiac and pulmonary dis- \\
& ease, immunodeficiency, accompanying respiratory failure, requiring mechanical ventilation, inhaling \\
& the nebulised $3 \%$ hypertonic saline solution and salbutamol $12 \mathrm{~h}$ before treatment, and premature in- \\
& fants born at less than 34 weeks gestation \\
\hline Interventions & Intervention group: nebulised $3 \%$ hypertonic saline (4 mL) plus 2.5 mg salbutamol \\
& Control group: nebulised $0.9 \%$ normal saline (4 mL) plus 2.5 mg salbutamol \\
Infants in each group received 3 treatments every day, delivered at intervals of $8 \mathrm{~h}$ until discharge us- \\
ing air-compressed nebulisers.
\end{tabular}

Notes RSV positive: $70 \%$ in hypertonic saline group; $69.7 \%$ in normal saline group

\section{Risk of bias}

\begin{tabular}{lll}
\hline Bias & Authors' judgement & Support for judgement \\
\hline $\begin{array}{l}\text { Random sequence genera- } \\
\text { tion (selection bias) }\end{array}$ & Unclear risk & No details were reported. \\
\hline $\begin{array}{l}\text { Allocation concealment } \\
\text { (selection bias) }\end{array}$ & Low risk & $\begin{array}{l}\text { No detectable difference in colour, smell, or other physical properties between } \\
\text { the therapeutic packages containing 0.9\% saline solution or 3\% saline solu- } \\
\text { tion. The codes of the therapeutic packages were not available to the investi- } \\
\text { gators, nurses, or parents. }\end{array}$ \\
\hline $\begin{array}{l}\text { Blinding (performance } \\
\text { bias and detection bias) }\end{array}$ & Low risk & Double-blind \\
\hline $\begin{array}{l}\text { All outcomes } \\
\begin{array}{l}\text { Incompltrition bias) } \\
\text { All outcomes }\end{array}\end{array}$ & Low risk & No withdrawals reported. \\
\hline $\begin{array}{l}\text { Selective reporting (re- } \\
\text { porting bias) }\end{array}$ & Low risk & All predefined outcomes reported. \\
\hline \begin{tabular}{l} 
Other bias \\
\hline
\end{tabular} & Low risk & No other bias found. \\
\hline
\end{tabular}


Luo 2011

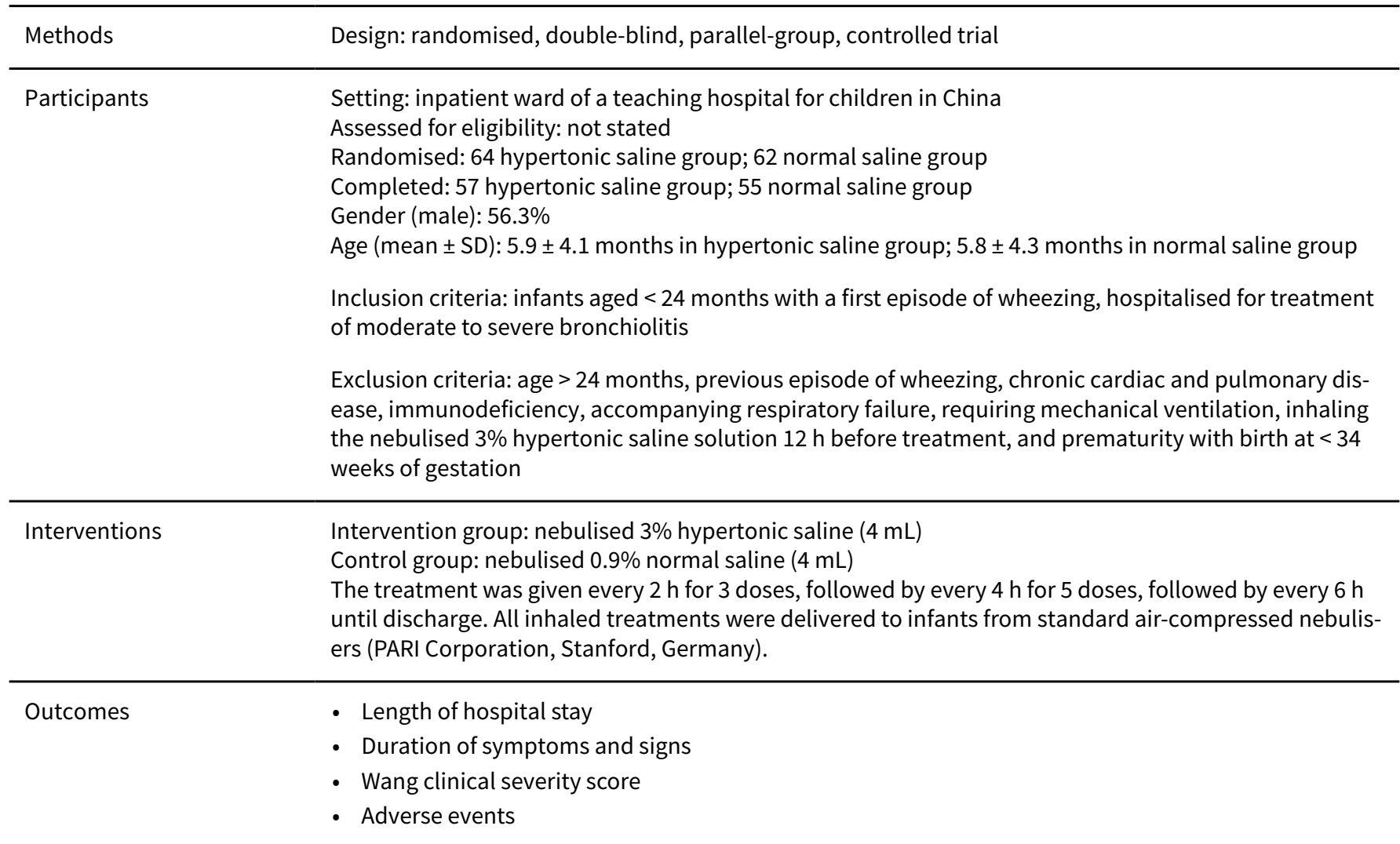

Notes

RSV positive: $73.7 \%$ in hypertonic saline group; $72.7 \%$ in normal saline group

\section{Risk of bias}

\begin{tabular}{lll}
\hline Bias & Authors' judgement & Support for judgement \\
\hline $\begin{array}{l}\text { Random sequence genera- } \\
\text { tion (selection bias) }\end{array}$ & Low risk & Computer-based randomisation program \\
\hline $\begin{array}{l}\text { Allocation concealment } \\
\text { (selection bias) }\end{array}$ & Low risk & Sequentially numbered, sealed, opaque envelopes \\
\hline $\begin{array}{l}\text { Blinding (performance } \\
\text { bias and detection bias) } \\
\text { All outcomes }\end{array}$ & Low risk & Double-blind \\
\hline $\begin{array}{l}\text { Incomplete outcome data } \\
\begin{array}{l}\text { (attrition bias) } \\
\text { All outcomes }\end{array}\end{array}$ & Low risk & 14 (11.1\%) withdrawals (7 infants from each group) \\
\hline $\begin{array}{l}\text { Selective reporting (re- } \\
\text { porting bias) }\end{array}$ & Low risk & All predefined outcomes reported. \\
\hline \begin{tabular}{l} 
Other bias \\
\hline
\end{tabular} & Low risk & No other bias found. \\
\hline
\end{tabular}


Mahesh Kumar 2013

\begin{tabular}{|c|c|}
\hline Methods & Design: randomised, double-blind, parallel-group, controlled trial \\
\hline \multirow[t]{8}{*}{ Participants } & Setting: inpatient ward of a teaching hospital in India \\
\hline & Assessed for eligibility: 78 \\
\hline & Randomised: 20 hypertonic saline group; 20 normal saline group \\
\hline & Completed: 20 hypertonic saline group; 20 normal saline group \\
\hline & Gender (male): $62.5 \%$ \\
\hline & Age (mean $\pm S D): 5.9 \pm 3.8$ months \\
\hline & $\begin{array}{l}\text { Inclusion criteria: children aged }<2 \text { years, hospitalised with acute bronchiolitis defined as the first } \\
\text { episode of lower respiratory tract infection with wheeze and having a moderate respiratory distress } \\
\text { with clinical severity score between } 4 \text { and } 8\end{array}$ \\
\hline & $\begin{array}{l}\text { Exclusion criteria: children with pre-existing cardiac disease, previous wheezing episodes, severe dis- } \\
\text { ease (clinical severity score }>8 \text { ) requiring mechanical ventilation }\left(\mathrm{SaO}_{2}<85 \% \text { on room air, cyanosis, ob- }\right. \\
\text { tunded consciousness, and/or progressive respiratory failure) }\end{array}$ \\
\hline \multirow[t]{3}{*}{ Interventions } & Intervention group: nebulised $3 \%$ hypertonic saline $(3 \mathrm{~mL})$ plus salbutamol $(0.15 \mathrm{mg} / \mathrm{kg})$ \\
\hline & Control group: nebulised $0.9 \%$ normal saline $(3 \mathrm{~mL})$ plus salbutamol $(0.15 \mathrm{mg} / \mathrm{kg})$ \\
\hline & $\begin{array}{l}\text { The medication was given via a nebuliser driven by oxygen flow at } 5 \text { to } 6 \mathrm{~L} / \mathrm{min} \text {, every } 6 \mathrm{~h} \text { until ready for } \\
\text { discharge. }\end{array}$ \\
\hline \multirow[t]{3}{*}{ Outcomes } & - Length of hospital stay \\
\hline & - Wang clinical severity score \\
\hline & - Number of add-on nebulisation \\
\hline Notes & Virological identification not available. \\
\hline
\end{tabular}

\section{Risk of bias}

\begin{tabular}{lll}
\hline Bias & Authors' judgement & Support for judgement \\
\hline $\begin{array}{l}\text { Random sequence genera- } \\
\text { tion (selection bias) }\end{array}$ & Low risk & Computer-generated randomisation \\
\hline $\begin{array}{l}\text { Allocation concealment } \\
\text { (selection bias) }\end{array}$ & Unclear risk & No details provided. \\
\hline $\begin{array}{l}\text { Blinding (performance } \\
\text { bias and detection bias) } \\
\text { All outcomes }\end{array}$ & Unclear risk & The trial was stated as double-blind, but no details were provided. \\
\hline $\begin{array}{l}\text { Incomplete outcome data } \\
\text { (attrition bias) } \\
\text { All outcomes }\end{array}$ & Low risk & No withdrawals reported. \\
\hline $\begin{array}{l}\text { Selective reporting (re- } \\
\text { porting bias) }\end{array}$ & Low risk & All predefined outcomes reported. \\
\hline \begin{tabular}{l} 
Other bias \\
\hline
\end{tabular} & Low risk & No other bias found. \\
\hline
\end{tabular}

Methods Design: randomised, double-blind, parallel-group, controlled trial


Mandelberg 2003 (Continued)

Participants Setting: paediatric inpatient ward, Edith Wolfson Medical Center, Israel

Eligible: not stated

Randomised: 27 (3\% saline group); 26 (0.9\% saline group)

Completed: 27 hypertonic saline group; 25 normal saline group

Gender (male): $57.7 \%$

Age (mean $\pm \mathrm{SD}$ ): $2.9 \pm 2.1$ months (range 0.5 to 12 months)

Inclusion criteria: infants with clinical presentation of viral bronchiolitis with temperature $>38^{\circ} \mathrm{C}$ that

led to hospitalisation

Exclusion criteria: cardiac disease, chronic respiratory disease, previous wheezing episode, age > 12 months, $\mathrm{SaO}_{2}<85 \%$ in room air, changes in consciousness and/or progressive respiratory failure requiring mechanical ventilation

Interventions

Intervention group: nebulised $3 \%$ saline solution $(4 \mathrm{~mL})$ plus $1.5 \mathrm{mg}$ epinephrine

Control group: nebulised $0.9 \%$ saline solution $(4 \mathrm{~mL}$ ) plus $1.5 \mathrm{mg}$ epinephrine

The treatment was given 3 times/day at intervals of $8 \mathrm{~h}$, until the infant was ready for discharge. All in-

haled treatments were delivered using a nebuliser (Aeromist Nebulizer Set 61400; B\&F Medical by Al-

lied; Toledo, $\mathrm{OH}$ ) connected to a source of pressurised oxygen at a flow rate of $5 \mathrm{~L} / \mathrm{min}$.

\begin{tabular}{ll}
\hline Outcomes & - Length of hospital stay \\
- Wang clinical severity score \\
- Oxygen saturation \\
- Rulse rate \\
- Rudiograph assessment score \\
- Adverse events
\end{tabular}

Notes $\quad$ RSV positive: $85 \%$ in hypertonic saline group; $88 \%$ in normal saline group

\section{Risk of bias}

\section{Bias Authors' judgement Support for judgement}

Random sequence genera- Unclear risk $\quad$ No details provided.
tion (selection bias)

tion (selection bias)

\begin{tabular}{|c|c|c|}
\hline $\begin{array}{l}\text { Allocation concealment } \\
\text { (selection bias) }\end{array}$ & Low risk & $\begin{array}{l}\text { Study solutions were similar in colour, smell, and other physical properties. } \\
\text { The code of the therapeutic package (hypertonic saline versus normal saline } \\
\text { solution) was deposited with the statistician. }\end{array}$ \\
\hline
\end{tabular}

Blinding (performance Low risk Double-blind

bias and detection bias)

All outcomes

\begin{tabular}{lll}
\hline $\begin{array}{l}\text { Incomplete outcome data } \\
\text { (attrition bias) } \\
\text { All outcomes }\end{array}$ & Low risk & $1(1.8 \%)$ withdrawal after randomisation \\
\hline $\begin{array}{l}\text { Selective reporting (re- } \\
\text { porting bias) }\end{array}$ & Low risk & All predefined outcomes reported. \\
\hline Other bias & Low risk & No other bias found. \\
\hline
\end{tabular}


Miraglia Del Giudice 2012

\begin{tabular}{ll}
\hline Methods & Design: randomised, double-blind, parallel-group, controlled trial \\
\hline Participants & Setting: division of paediatrics of a general hospital in Italy \\
& Assessed for eligibility: 136 \\
& Randomised: 53 hypertonic saline group; 56 normal saline group \\
Completed: 52 hypertonic saline group; 54 normal saline group \\
Gender (male): $65.1 \%$ \\
Age (mean \pm SD): $4.8 \pm 2.3$ months in hypertonic saline group; $4.2 \pm 1.6$ months in normal saline group \\
Inclusion criteria: children aged under 2 years with a diagnosis of bronchiolitis, defined as the first \\
episode of wheezing and clinical symptoms of a viral respiratory infection and SaO ${ }_{2}<94 \%$ in room air \\
and significant respiratory distress \\
Exclusion criteria: pre-existing cardiac or pulmonary diseases, premature birth $<36$ weeks of gestation- \\
al age, previous diagnosis of asthma, initial SaO $\mathrm{O}_{2} \leq 85 \%$ or respiratory distress severe enough to require \\
resuscitation
\end{tabular}

\begin{tabular}{|c|c|}
\hline \multirow[t]{3}{*}{ Interventions } & $\begin{array}{l}\text { Intervention group: nebulised 3.0\% hypertonic saline (the volume not reported) plus } 1.5 \mathrm{mg} \text { epineph- } \\
\text { rine }\end{array}$ \\
\hline & Control group: nebulised $0.9 \%$ normal saline (the volume not reported) plus $1.5 \mathrm{mg}$ epinephrine \\
\hline & $\begin{array}{l}\text { Study solutions were given at intervals of } 6 \mathrm{~h} \text { until discharge. Each treatment was delivered by a nebu- } \\
\text { liser with continuous flow of oxygen at } 6 \mathrm{~L} / \mathrm{min} \text { through a tight-fitting face mask }\end{array}$ \\
\hline
\end{tabular}

\begin{tabular}{ll}
\hline Outcomes & Length of hospital stay \\
& - Wang clinical severity score
\end{tabular}

Notes

RSV positive: $80.7 \%$ in hypertonic saline group; $83.3 \%$ in normal saline group

\section{Risk of bias}

\begin{tabular}{|c|c|c|}
\hline Bias & Authors' judgement & Support for judgement \\
\hline $\begin{array}{l}\text { Random sequence genera- } \\
\text { tion (selection bias) }\end{array}$ & Low risk & Computer-based randomisation program \\
\hline $\begin{array}{l}\text { Allocation concealment } \\
\text { (selection bias) }\end{array}$ & Unclear risk & $\begin{array}{l}\text { Study solutions were prepared by the local hospital pharmacy, but the method } \\
\text { of allocation concealment was not described. }\end{array}$ \\
\hline $\begin{array}{l}\text { Blinding (performance } \\
\text { bias and detection bias) } \\
\text { All outcomes }\end{array}$ & Low risk & Double-blind \\
\hline $\begin{array}{l}\text { Incomplete outcome data } \\
\text { (attrition bias) } \\
\text { All outcomes }\end{array}$ & Low risk & 3 withdrawals ( 1 hypertonic saline group; 2 normal saline group) \\
\hline $\begin{array}{l}\text { Selective reporting (re- } \\
\text { porting bias) }\end{array}$ & Low risk & All predefined outcomes reported. \\
\hline Other bias & Low risk & No other bias found. \\
\hline
\end{tabular}


NCT01238848

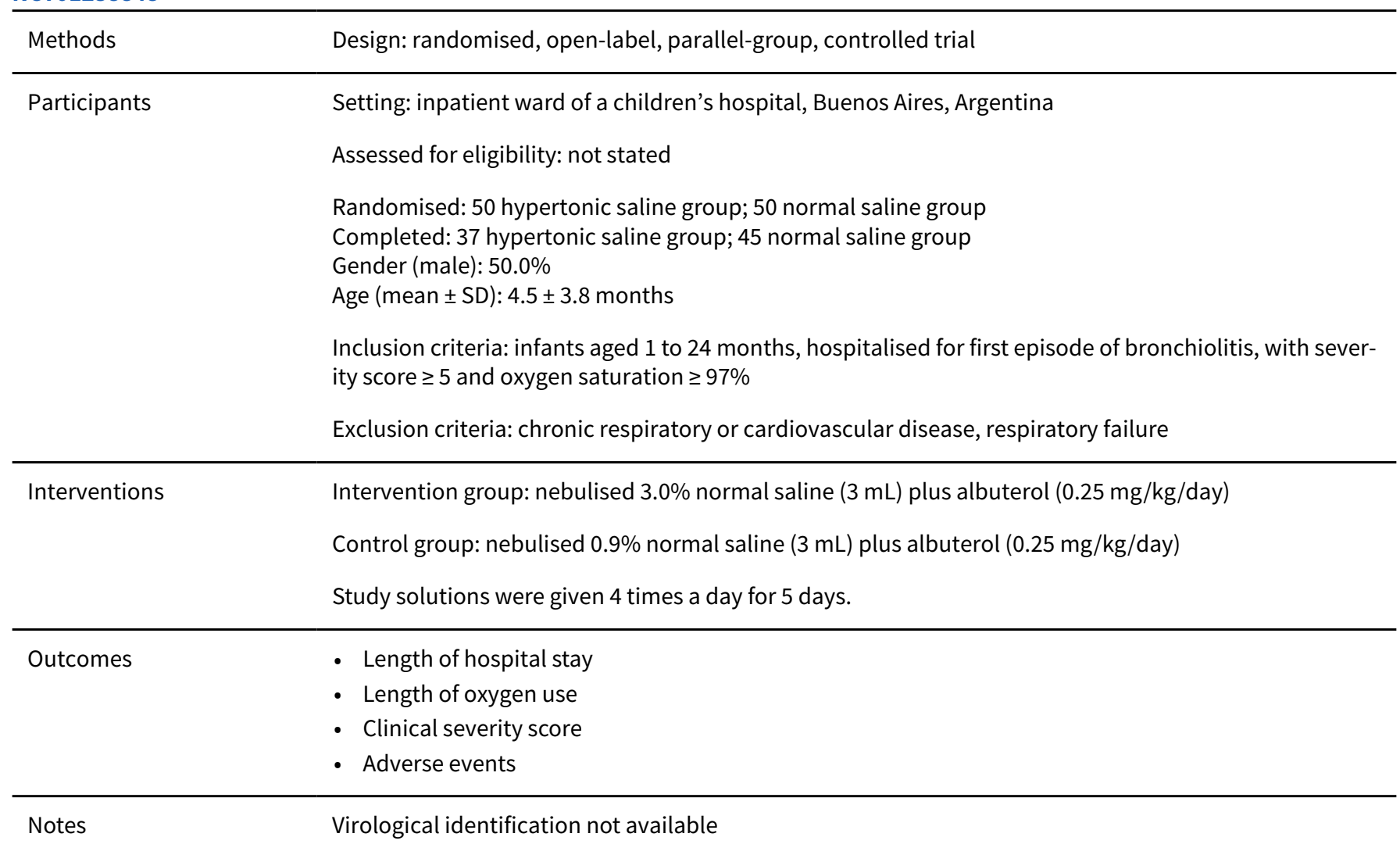

\section{Risk of bias}

Bias Authors' judgement Support for judgement

Random sequence genera- Unclear risk The trial was stated as randomised, but no details were provided tion (selection bias)

\begin{tabular}{lll}
\hline $\begin{array}{l}\text { Allocation concealment } \\
\text { (selection bias) }\end{array}$ & Unclear risk & No details provided \\
\hline $\begin{array}{l}\text { Blinding (performance } \\
\text { bias and detection bias) } \\
\text { All outcomes }\end{array}$ & High risk & Open-label \\
\hline $\begin{array}{l}\text { Incomplete outcome data } \\
\text { (attrition bias) } \\
\text { All outcomes }\end{array}$ & High risk & $\begin{array}{l}18(18 \%) \text { withdrawals (13 hypertonic saline group, } 5 \text { normal saline group); un- } \\
\text { balanced attrition between treatment groups }\end{array}$ \\
\hline $\begin{array}{l}\text { Selective reporting (re- } \\
\text { porting bias) }\end{array}$ & Low risk & All predefined outcomes reported \\
\hline Other bias & Low risk & No other bias found \\
\hline
\end{tabular}

\section{Ojha 2014}

Methods Design: randomised, double-blind, parallel-group, controlled trial

Participants Setting: inpatient ward of a teaching hospital in Nepal


Ojha 2014 (Continued)

Assessed for eligibility: 104

Randomised: 36 hypertonic saline group; 36 normal saline group

Completed: 28 hypertonic saline group; 31 normal saline group

Gender (male): $74 \%$

Age (mean $\pm S D): 8.5 \pm 5.0$ months

Inclusion criteria: children aged over 6 weeks up to 24 months, hospitalised with acute bronchiolitis, defined as the first episode of wheezing associated with tachypnoea, increased respiratory effort, and an upper respiratory tract infection

Exclusion criteria: previous episode of wheezing, chronic cardiac and pulmonary disease, immunodeficiency, accompanying respiratory failure, requiring mechanical ventilation, inhaling the nebulised $3 \%$ hypertonic saline solution and salbutamol $12 \mathrm{~h}$ before treatment, premature infants born at less than 34 weeks gestation, $\mathrm{SaO}_{2}<85 \%$ on room air

\begin{tabular}{ll}
\hline Interventions & Intervention group: nebulised $3 \%$ hypertonic saline $(4 \mathrm{~mL})$ \\
& $\begin{array}{l}\text { Control group: nebulised } 0.9 \% \text { normal saline }(4 \mathrm{~mL}) \\
\text { The treatment was given every } 8 \mathrm{~h} \text { until discharge. }\end{array}$ \\
\hline Outcomes & - Length of hospital stay \\
& - Clinical severity score \\
& Duration of oxygen supplementation \\
\hline
\end{tabular}

Notes

Virological identification not available.

\section{Risk of bias}

\begin{tabular}{|c|c|c|}
\hline Bias & Authors' judgement & Support for judgement \\
\hline $\begin{array}{l}\text { Random sequence genera- } \\
\text { tion (selection bias) }\end{array}$ & Low risk & Computer-generated randomisation \\
\hline $\begin{array}{l}\text { Allocation concealment } \\
\text { (selection bias) }\end{array}$ & Low risk & $\begin{array}{l}\text { The random numbers were kept in a sealed envelope. The solutions looked } \\
\text { similar in appearance and smell and were kept in } 2 \text { identical containers, la- } \\
\text { belled only by a code number. }\end{array}$ \\
\hline $\begin{array}{l}\text { Blinding (performance } \\
\text { bias and detection bias) } \\
\text { All outcomes }\end{array}$ & Low risk & Double-blind \\
\hline $\begin{array}{l}\text { Incomplete outcome data } \\
\text { (attrition bias) } \\
\text { All outcomes }\end{array}$ & Low risk & $\begin{array}{l}13(18 \%) \text { withdrawals after randomisation ( } 8 \text { hypertonic saline group; } 5 \text { nor- } \\
\text { mal saline group); baseline characteristics between treatment groups were } \\
\text { balanced. }\end{array}$ \\
\hline $\begin{array}{l}\text { Selective reporting (re- } \\
\text { porting bias) }\end{array}$ & Low risk & All predefined outcomes reported. \\
\hline Other bias & Low risk & No other bias found. \\
\hline
\end{tabular}

Pandit 2013

\begin{tabular}{ll}
\hline Methods & Design: randomised, non-blind, parallel-group, controlled trial \\
\hline Participants & Setting: paediatric department of a government multi-speciality hospital in India \\
& Assessed for eligibility: not stated
\end{tabular}


Pandit 2013 (Continued)

Randomised: 51 hypertonic saline group; 49 normal saline group

Completed: 51 hypertonic saline group; 49 normal saline group

Gender (male): not reported

Age: mean age: not reported

Inclusion criteria: infants aged 2 months to 12 months, admitted with clinical diagnosis of acute bronchiolitis, defined as the first attack of wheezing after a short history of cough with or without fever of less than 7 days duration

Exclusion criteria: recurrent episodes of wheezing, 1 or more episodes of respiratory distress in past, family history of asthma, atopy, congenital heart disease, history of prematurity or mechanical ventilation in newborn period, very sick patients with shock, seizures, heart rate $>180 / \mathrm{min}$, respiratory rate $>$ $100 / \mathrm{min}$ and adjudged to be in incipient respiratory failure, severe malnutrition, consolidation lung on chest X-ray

Interventions Intervention group: nebulised 3\% hypertonic saline $(4 \mathrm{~mL})$ plus 1:1000 adrenaline $(1 \mathrm{~mL})$

Control group: nebulised $0.9 \%$ normal saline $(4 \mathrm{~mL})$ plus 1:1000 adrenaline $(1 \mathrm{~mL})$

The medication was given 3 times with an interval of 1 hour, via a nebuliser driven by oxygen flow at 6 to $8 \mathrm{~L} / \mathrm{min}$.

\begin{tabular}{ll}
\hline Outcomes & - Length of hospital stay \\
- RDAl & Oxygen saturation \\
- Respiratory rate \\
- Heart rate \\
- Number of add-on treatments \\
- Adverse events
\end{tabular}

Notes Virological identification not available.

\section{Risk of bias}

\begin{tabular}{|c|c|c|}
\hline Bias & Authors' judgement & Support for judgement \\
\hline $\begin{array}{l}\text { Random sequence genera- } \\
\text { tion (selection bias) }\end{array}$ & Low risk & Computer-generated randomisation \\
\hline $\begin{array}{l}\text { Allocation concealment } \\
\text { (selection bias) }\end{array}$ & Low risk & Group allocation was concealed in an opaque envelope. \\
\hline $\begin{array}{l}\text { Blinding (performance } \\
\text { bias and detection bias) } \\
\text { All outcomes }\end{array}$ & High risk & Non-blind \\
\hline $\begin{array}{l}\text { Incomplete outcome data } \\
\text { (attrition bias) } \\
\text { All outcomes }\end{array}$ & Low risk & No withdrawals reported. \\
\hline $\begin{array}{l}\text { Selective reporting (re- } \\
\text { porting bias) }\end{array}$ & Low risk & All predefined outcomes reported. \\
\hline Other bias & Low risk & No other bias found. \\
\hline
\end{tabular}


Ratajczyk-Pekrul 2016

\begin{tabular}{|c|c|}
\hline Methods & Design: randomised, double-blind, parallel-group, controlled trial \\
\hline \multirow[t]{8}{*}{ Participants } & Setting: inpatient ward of a general hospital in Poland \\
\hline & Assessed for eligibility: 80 \\
\hline & Randomised: 41 hypertonic saline group; 37 normal saline group \\
\hline & Completed: 41 hypertonic saline group; 36 normal saline group \\
\hline & Gender (male): $58.9 \%$ \\
\hline & Age (mean): 5.34 months in hypertonic saline group; 4.43 months in normal saline group \\
\hline & $\begin{array}{l}\text { Inclusion criteria: children aged } 0 \text { to } 18 \text { months, hospitalised with acute bronchiolitis, defined as pro- } \\
\text { longed expiration, wheezes, and crepitations, with a history of a preceding viral upper respiratory in- } \\
\text { fection, and with } \mathrm{SaO}_{2} \leq 95 \% \text { or Wang score } \geq 5\end{array}$ \\
\hline & $\begin{array}{l}\text { Exclusion criteria: preterm babies < } 34 \text { weeks, chronic cardiac or respiratory disease, immunologi- } \\
\text { cal deficiencies, } 2 \text { or more episodes of bronchial obstruction, treatment with systemic glucocorticos- } \\
\text { teroids, received a hypertonic saline nebulisation in } 24 \text { hours prior to admission, or with } \mathrm{SaO}_{2}<85 \%\end{array}$ \\
\hline \multirow[t]{3}{*}{ Interventions } & Intervention group: nebulised 3\% hypertonic saline $(3 \mathrm{~mL})$ plus salbutamol $(0.15 \mathrm{mg} / \mathrm{kg}$, max $1.5 \mathrm{mg})$ \\
\hline & Control group: nebulised $0.9 \%$ normal saline ( $3 \mathrm{~mL}$ ) plus salbutamol $(0.15 \mathrm{mg} / \mathrm{kg}$, max $1.5 \mathrm{mg})$ \\
\hline & $\begin{array}{l}\text { The medication was given } 6 \text { times daily until discharge, via a nebuliser driven by oxygen flow at } 6 \text { to } 8 \\
\mathrm{~L} / \mathrm{min} \text {. }\end{array}$ \\
\hline \multirow[t]{3}{*}{ Outcomes } & - Length of hospital stay \\
\hline & - Improvement in clinical severity score at 24,48 , and $72 \mathrm{~h}$ after hospital admission \\
\hline & - Adverse events \\
\hline
\end{tabular}

\section{Risk of bias}

Bias Authors' judgement Support for judgement

Random sequence genera- Low risk Computer-generated randomisation

tion (selection bias)

Allocation concealment $\quad$ Unclear risk No details provided.
(selection bias)

\begin{tabular}{|c|c|c|}
\hline $\begin{array}{l}\text { Blinding (performance } \\
\text { bias and detection bias) } \\
\text { All outcomes }\end{array}$ & Low risk & Double-blind \\
\hline $\begin{array}{l}\text { Incomplete outcome data } \\
\text { (attrition bias) } \\
\text { All outcomes }\end{array}$ & Low risk & 4 (5.1\%) withdrawals ( 2 infants from each group) \\
\hline $\begin{array}{l}\text { Selective reporting (re- } \\
\text { porting bias) }\end{array}$ & Low risk & All predefined outcomes reported. \\
\hline Other bias & Unclear risk & No other bias found. \\
\hline
\end{tabular}

Methods Design: randomised, double-blind, parallel-group, controlled trial


Sarrell 2002 (Continued)

Participants

Setting: Paediatrics and Adolescent Ambulatory Community Clinic of General Health Services of

Petach-Tikva, Israel

Eligible: not stated

Randomised: 70

Completed: 33 (3\% saline group); 32 (0.9\% saline group)

Gender (male): $59 \%$

Age (mean $\pm \mathrm{SD}): 12.5 \pm 6.0$ months (range 3 to 24 months)

Inclusion criteria: infants with clinical presentation of mild to moderate viral bronchiolitis

Exclusion criteria: cardiac disease, chronic respiratory disease, previous wheezing episode, age $\geq 24$

months, $\mathrm{SaO}_{2}<96 \%$ on room air, and need for hospitalisation

Interventions Intervention group: nebulised $3 \%$ saline solution $(2 \mathrm{~mL})$ plus $5 \mathrm{mg}(0.5 \mathrm{~mL})$ terbutaline

Control group: nebulised $0.9 \%$ saline solution $(2 \mathrm{~mL})$ plus $5 \mathrm{mg}(0.5 \mathrm{~mL})$ terbutaline

The treatment was given 3 times/day at intervals of $8 \mathrm{~h}$ for 5 days.

\begin{tabular}{ll}
\hline Outcomes & Wang clinical severity score \\
- Hospitalisation rate \\
- Radiograph assessment score \\
- Pulse rate \\
- Adverse events \\
\hline Notes & RSV positive: $82 \%$ in hypertonic saline group; $78 \%$ in normal saline group
\end{tabular}

\section{Risk of bias}

\begin{tabular}{|c|c|c|}
\hline Bias & Authors' judgement & Support for judgement \\
\hline $\begin{array}{l}\text { Random sequence genera- } \\
\text { tion (selection bias) }\end{array}$ & Low risk & Randomisation in blocks of 4 , using an online randomiser \\
\hline $\begin{array}{l}\text { Allocation concealment } \\
\text { (selection bias) }\end{array}$ & Low risk & $\begin{array}{l}\text { Study solutions were similar in colour, smell, and other physical properties. } \\
\text { The code of the therapeutic package (hypertonic saline versus normal saline } \\
\text { solution) was deposited with the statistician. }\end{array}$ \\
\hline $\begin{array}{l}\text { Blinding (performance } \\
\text { bias and detection bias) } \\
\text { All outcomes }\end{array}$ & Low risk & Double-blind \\
\hline $\begin{array}{l}\text { Incomplete outcome data } \\
\text { (attrition bias) } \\
\text { All outcomes }\end{array}$ & Low risk & $5(7.1 \%)$ withdrawals after randomisation \\
\hline $\begin{array}{l}\text { Selective reporting (re- } \\
\text { porting bias) }\end{array}$ & Low risk & All predefined outcomes reported. \\
\hline Other bias & Low risk & No other bias found. \\
\hline
\end{tabular}

Sharma 2013

\begin{tabular}{ll}
\hline Methods & Design: randomised, double-blind, parallel-group, controlled trial \\
\hline Participants & Setting: inpatient ward of a tertiary care teaching hospital in India \\
& Assessed for eligibility: 277 \\
Randomised: 125 hypertonic saline group; 125 normal saline group \\
\hline
\end{tabular}


Sharma 2013 (Continued)

Completed: 125 hypertonic saline group; 123 normal saline group

Gender (male): $76.2 \%$

Age (mean $\pm S D): 8.5 \pm 5.0$ months

Inclusion criteria: infants aged 1 to 24 months, hospitalised with moderate (clinical severity score 3 to

6) acute bronchiolitis, defined by the first episode of wheezing along with prodrome of upper respirato-

ry tract infection

Exclusion criteria: children with obtunded consciousness, cardiac disease, chronic respiratory disease, previous wheezing episode, progressive respiratory distress requiring respiratory support other than supplemental oxygen, use of nebulised hypertonic saline within the previous $12 \mathrm{~h}$

Interventions Intervention group: nebulised $3 \%$ hypertonic saline $(4 \mathrm{~mL})$ plus salbutamol $(2.5 \mathrm{mg})$

Control group: nebulised $0.9 \%$ normal saline $(4 \mathrm{~mL})$ plus salbutamol $(2.5 \mathrm{mg})$

The medication was given via a jet nebuliser with tight-fitting face mask, driven by oxygen flow at $7 \mathrm{~L} /$ min, every $4 \mathrm{~h}$ until the infant was ready for discharge.

\begin{tabular}{ll}
\hline Outcomes & - Length of hospital stay \\
& $\cdot$ Wang clinical severity score \\
& - Adverse events \\
\hline Notes & Virological identification not available. \\
\hline
\end{tabular}

\section{Risk of bias}

\begin{tabular}{|c|c|c|}
\hline Bias & Authors' judgement & Support for judgement \\
\hline $\begin{array}{l}\text { Random sequence genera- } \\
\text { tion (selection bias) }\end{array}$ & Low risk & Computer-generated randomisation \\
\hline $\begin{array}{l}\text { Allocation concealment } \\
\text { (selection bias) }\end{array}$ & Low risk & $\begin{array}{l}\text { Study solutions were similar in colour, smell, and other physical properties. } \\
\text { The code of the therapeutic package (hypertonic saline versus normal saline } \\
\text { solution) was deposited with the statistician. }\end{array}$ \\
\hline $\begin{array}{l}\text { Blinding (performance } \\
\text { bias and detection bias) } \\
\text { All outcomes }\end{array}$ & Low risk & Double-blind \\
\hline $\begin{array}{l}\text { Incomplete outcome data } \\
\text { (attrition bias) } \\
\text { All outcomes }\end{array}$ & Low risk & $2(0.8 \%)$ withdrawals after randomisation in normal saline group \\
\hline $\begin{array}{l}\text { Selective reporting (re- } \\
\text { porting bias) }\end{array}$ & Low risk & All predefined outcomes reported. \\
\hline Other bias & Low risk & No other bias found. \\
\hline
\end{tabular}

\section{Tal 2006}

\begin{tabular}{ll}
\hline Methods & Design: randomised, double-blind, parallel-group, controlled trial \\
\hline Participants & Setting: paediatric inpatient ward, Wolfson Medical Center, Israel \\
& Eligible: not stated \\
& Randomised: 22 hypertonic saline group; 22 normal saline group \\
& Completed: 21 hypertonic saline group; 20 normal saline group \\
& Gender (male): $56.1 \%$
\end{tabular}


Tal 2006 (Continued)

Age (mean $\pm S D): 2.6 \pm 1.0$ months (range 1 to 5 months)

Inclusion criteria: infants with clinical presentation of viral bronchiolitis that led to hospitalisation

Exclusion criteria: cardiac disease, chronic respiratory disease, previous wheezing episode, age > 12 months, $\mathrm{SaO}_{2}<85 \%$ on room air, obtunded consciousness and/or progressive respiratory failure requiring mechanical ventilation

$\begin{array}{ll}\text { Interventions } & \text { Intervention group: nebulised } 3 \% \text { saline solution }(4 \mathrm{~mL}) \text { plus } 1.5 \mathrm{mg} \text { epinephrine } \\ \text { Control group: nebulised } 0.9 \% \text { saline solution }(4 \mathrm{~mL}) \text { plus } 1.5 \mathrm{mg} \text { epinephrine. }\end{array}$

The treatment was given 3 times/day at intervals of $8 \mathrm{~h}$, until the infant was ready for discharge. All inhaled treatments were delivered using an ultrasonic nebuliser (Omron UI, OMRON Matsusaka Co. Ltd, Japan)

\begin{tabular}{ll}
\hline Outcomes & - Length of hospital stay \\
& - Wang clinical severity score \\
& - Adverse events \\
\hline Notes & RSV positive: $86 \%$ in hypertonic saline group; $75 \%$ in normal saline group \\
\hline
\end{tabular}

\section{Risk of bias}

\begin{tabular}{lll}
\hline Bias & Authors' judgement & Support for judgement \\
\hline $\begin{array}{l}\text { Random sequence genera- } \\
\text { tion (selection bias) }\end{array}$ & Low risk & Randomisation in blocks of 4, using an online randomiser \\
\hline $\begin{array}{l}\text { Allocation concealment } \\
\text { (selection bias) }\end{array}$ & Low risk & $\begin{array}{l}\text { Study solutions were similar in colour, smell, and other physical properties. } \\
\text { The code of the therapeutic package (hypertonic saline versus normal saline } \\
\text { solution) was deposited with the statistician. }\end{array}$ \\
\hline $\begin{array}{l}\text { Blinding (performance } \\
\text { bias and detection bias) } \\
\text { All outcomes }\end{array}$ & Low risk & Double-blind \\
\hline $\begin{array}{l}\text { Incomplete outcome data } \\
\text { (attrition bias) }\end{array}$ & Low risk & $\begin{array}{l}\text { All outcomes } \\
\text { saline group) }\end{array}$ \\
\hline $\begin{array}{l}\text { Selective reporting (re- } \\
\text { porting bias) }\end{array}$ & Low risk & All predefined outcomes reported. \\
\hline \begin{tabular}{l} 
Other bias \\
\hline
\end{tabular} & Low risk & No other bias found. \\
\hline
\end{tabular}

Teunissen 2014

\begin{tabular}{ll}
\hline Methods & Design: randomised, double-blind, parallel-group, controlled trial \\
\hline Participants & Setting: inpatient wards of 11 general hospitals and 1 tertiary medical centre in the Netherlands \\
& Assessed for eligibility: not stated \\
& Randomised: 97 ( $3 \%$ saline group); 102 (6\% saline group); 93 (normal saline group) \\
Completed: 84 (3\% saline group); 83 (6\% saline group); 80 (normal saline group) \\
Gender (male): $57.1 \%$ \\
Age: median 3.4 months (range 10 days to 23 months)
\end{tabular}


Teunissen 2014 (Continued)

Inclusion criteria: children aged birth to 24 months, hospitalised with mild to severe (Wang clinical severity score $\geq 3$ ) viral bronchiolitis, defined as symptoms of an upper respiratory tract infection with wheezing, tachypnoea, and dyspnoea

Exclusion criteria: Wang clinical severity score improved at least 2 points after inhalation of $2.5 \mathrm{mg}$ salbutamol, haemodynamically important congenital heart disease, chronic pre-existent lung disease, T-cell immunodeficiency, treatment with corticosteroids, and previous wheezing, (food) allergy, or eczema

\begin{tabular}{ll}
\hline Interventions & Intervention groups: \\
& Nebulised $3 \%$ hypertonic saline $(4 \mathrm{~mL})$ plus salbutamol $(2.5 \mathrm{mg})$ \\
& Nebulised $6 \%$ hypertonic saline $(4 \mathrm{~mL})$ plus salbutamol $(2.5 \mathrm{mg})$ \\
& Control group: nebulised $0.9 \%$ normal saline $(4 \mathrm{~mL})$ plus salbutamol $(2.5 \mathrm{mg})$ \\
The solutions were given via a HOT Top Plus Nebuliser (Intersurgical, Uden, Nether \\
fitting face mask, driven by oxygen flow at 6 to $8 \mathrm{~L} / \mathrm{min}$, every 8 h until discharge. \\
- Length of hospital stay \\
- Transfer to a paediatric intensive care unit because of respiratory insufficiency \\
- Need and duration of supplemental oxygen or tube feeding \\
- Adverse events
\end{tabular}

Notes $\quad$ RSV positive: $83.7 \%$ in $3 \%$ saline group; $91.4 \%$ in $6 \%$ saline group; $88.6 \%$ in control group

\section{Risk of bias}

\begin{tabular}{lll}
\hline Bias & Authors' judgement & Support for judgement \\
\hline $\begin{array}{l}\text { Random sequence genera- } \\
\text { tion (selection bias) }\end{array}$ & Unclear risk & $\begin{array}{l}\text { Block randomisation (in blocks of 6), but it is unclear how to choose blocks at } \\
\text { random to create the allocation sequence. }\end{array}$ \\
\hline $\begin{array}{l}\text { Allocation concealment } \\
\text { (selection bias) }\end{array}$ & Low risk & $\begin{array}{l}\text { Study solutions were identical in vial packaging, colour, smell, and other physi- } \\
\text { cal characteristics. The trial codes were kept by the pharmacist. }\end{array}$ \\
\hline $\begin{array}{l}\text { Blinding (performance } \\
\text { bias and detection bias) } \\
\text { All outcomes }\end{array}$ & Low risk & Double-blind \\
\hline
\end{tabular}

Incomplete outcome data Low risk (attrition bias)

All outcomes

Selectivereporting (re-

Selective reporting (re- Low risk porting bias)
$43(14.7 \%)$ withdrawals after randomisation (13 (3\% saline group), 18 (6\% saline group), 12 (normal saline group)); baseline characteristics between treatment groups were balanced.

Other bias Low risk No other bias found.

Tinsa 2014

\begin{tabular}{ll}
\hline Methods & Design: randomised, double-blind, parallel-group, controlled trial \\
\hline Participants & Setting: inpatient ward of a children's hospital in Tunisia \\
& Assessed for eligibility: not stated \\
Randomised: 32 ( $5 \%$ saline group); 37 (5\% saline + epinephrine group); 28 (normal saline group)
\end{tabular}


Tinsa 2014 (Continued)

Completed: 31 (5\% saline group); 37 (5\% saline + epinephrine group); 26 (normal saline group) Gender (male): $61.7 \%$

Age (mean \pm SD): $3.7 \pm 2.8$ months in $5 \%$ saline group; $3.2 \pm 2.5$ months in $5 \%$ saline + epinephrine group; $3.0 \pm 2.4$ months in normal saline group

Inclusion criteria: children aged 1 to 12 months, hospitalised with moderate (Wang clinical severity score of 3) bronchiolitis, defined as an acute infection of the lower respiratory tract, preceded by or accompanied by fever or rhinitis, or both, and characterised by expiratory wheezing and increased respiratory effort

Exclusion criteria: prematurity (gestational age at birth $<34$ weeks), underlying chronic cardiac or pulmonary disease (e.g. bronchopulmonary dysplasia, cystic fibrosis), recurrent wheezing, severe respiratory distress (apnoeas, heart rate $>200$ beats per minute, respiratory rate $>80$ breaths/minute, profound lethargy, duration of illness exceeding 15 days)

\begin{tabular}{ll}
\hline Interventions & Intervention groups: \\
& Nebulised $5 \%$ hypertonic saline $(4 \mathrm{~mL})$ \\
& Nebulised $5 \%$ hypertonic saline $(2 \mathrm{~mL})$ plus standard epinephrine $(2 \mathrm{~mL})$ \\
& Control group: nebulised $0.9 \%$ normal saline $(4 \mathrm{~mL})$ \\
& The solutions were given via a jet nebuliser with a tight-fitting face mask, driven by oxygen flow at 6 to 7 \\
& L/min, every 4 h until discharge. \\
\hline Outcomes & Wang clinical severity score \\
- & Length of hospital stay \\
- & Rerpiratory rate \\
- Adverse events
\end{tabular}

\section{Risk of bias}

\begin{tabular}{lll}
\hline Bias & Authors' judgement & Support for judgement \\
\hline $\begin{array}{l}\text { Random sequence genera- } \\
\text { tion (selection bias) }\end{array}$ & Low risk & Computer-generated randomisation \\
\hline $\begin{array}{l}\text { Allocation concealment } \\
\text { (selection bias) }\end{array}$ & Low risk & $\begin{array}{l}\text { Study solutions were similar in appearance and smell and were stored in iden- } \\
\text { tical syringes, labelled only by a code number. }\end{array}$ \\
\hline $\begin{array}{l}\text { Blinding (performance } \\
\text { bias and detection bias) } \\
\text { All outcomes }\end{array}$ & Low risk & Double-blind \\
\hline $\begin{array}{l}\text { Incomplete outcome data } \\
\text { (attrition bias) } \\
\text { All outcomes }\end{array}$ & Low risk & $\begin{array}{l}3 \text { (3.1\%) withdrawals after randomisation (2 normal saline group, 1 hypertonic } \\
\text { saline group) }\end{array}$ \\
\hline $\begin{array}{l}\text { Selective reporting (re- } \\
\text { porting bias) }\end{array}$ & Low risk & All predefined outcomes reported. \\
\hline \begin{tabular}{l} 
Other bias \\
\hline
\end{tabular} & Low risk & No other bias found. \\
\hline
\end{tabular}


Wu 2014

\begin{tabular}{|c|c|}
\hline Methods & Design: randomised, double-blind, parallel-group, controlled trial \\
\hline \multirow[t]{8}{*}{ Participants } & Setting: emergency departments of 2 urban freestanding tertiary children's hospitals in USA \\
\hline & Assessed for eligibility: 1254 \\
\hline & Randomised: 211 hypertonic saline group; 197 normal saline group \\
\hline & Completed: 211 hypertonic saline group; 197 normal saline group \\
\hline & Gender (male): $56.8 \%$ \\
\hline & Age (mean $\pm S D): 6.5 \pm 5.1$ months in hypertonic saline group; $6.4 \pm 5.3$ months in normal saline group \\
\hline & $\begin{array}{l}\text { Inclusion criteria: children younger than } 24 \text { months with a primary diagnosis of viral bronchiolitis dur- } \\
\text { ing bronchiolitis season }\end{array}$ \\
\hline & $\begin{array}{l}\text { Exclusion criteria: children with a prior illness with wheezing or bronchodilator use, premature (gesta- } \\
\text { tional age < } 34 \text { weeks), cyanotic congenital heart disease, chronic lung disease, or tracheostomy }\end{array}$ \\
\hline \multirow[t]{3}{*}{ Interventions } & Intervention group: nebulised $3 \%$ hypertonic saline $(4 \mathrm{~mL})$ \\
\hline & Control group: nebulised $0.9 \%$ normal saline $(4 \mathrm{~mL})$ \\
\hline & $\begin{array}{l}\text { The solutions were given via a small-volume wall nebuliser at study entry. Emergency department } \\
\text { physicians could order } 2 \text { additional treatments every } 20 \text { minutes to a maximum of } 3 \text { inhaled doses. Ad- } \\
\text { mitted infants continued receiving study medication, every } 8 \text { h until discharge. }\end{array}$ \\
\hline \multirow[t]{5}{*}{ Outcomes } & - Admission rate \\
\hline & - Length of hospital stay \\
\hline & - RDAl \\
\hline & - Supplemental treatment use \\
\hline & - Adverse events \\
\hline
\end{tabular}

Notes $\quad$ RSV positive: $65.6 \%$ hypertonic saline group; $59.2 \%$ normal saline group

\section{Risk of bias}

\begin{tabular}{lll}
\hline Bias & Authors' judgement & Support for judgement \\
\hline $\begin{array}{l}\text { Random sequence genera- } \\
\text { tion (selection bias) }\end{array}$ & Low risk & Computer-generated randomisation \\
\hline $\begin{array}{l}\text { Allocation concealment } \\
\text { (selection bias) }\end{array}$ & Low risk & $\begin{array}{l}\text { Saline solutions were prepared by the investigational pharmacy and stored in } \\
\text { sequentially numbered identical vials. }\end{array}$ \\
\hline $\begin{array}{l}\text { Blinding (performance } \\
\text { bias and detection bias) } \\
\text { All outcomes }\end{array}$ & Low risk & Double-blinded \\
\hline
\end{tabular}

Incomplete outcome data Low risk No withdrawals reported at emergency department setting.

(attrition bias)

All outcomes

\begin{tabular}{lll}
\hline $\begin{array}{l}\text { Selective reporting (re- } \\
\text { porting bias) }\end{array}$ & Low risk & All predefined outcomes reported. \\
\hline Other bias & Low risk & No other bias found. \\
\hline
\end{tabular}

ICU: intensive care unit

RDAl: Respiratory Distress Assessment Instrument

RSV: respiratory syncytial virus 
$\mathrm{SaO}_{2}$ : oxygen saturation

SD: standard deviation

Characteristics of excluded studies [ordered by study ID]

\begin{tabular}{|c|c|}
\hline Study & Reason for exclusion \\
\hline Al-bahadily 2017 & $\begin{array}{l}\text { Not an RCT. The authors classified the study design as "prospective case second multicenter study" } \\
\text { in the Abstract and "Prospective comparison study" in the Methods. We contacted the first author } \\
\text { for more details about study design, but did not receive a reply. }\end{array}$ \\
\hline Amirav 2005 & Study of drug delivery (hood versus face mask) \\
\hline Bagus 2012 & Abstract available only \\
\hline Bueno Campaña 2014 & Other comparison (hypertonic saline versus high flow therapy) \\
\hline Flores-González 2015 & Other comparison (epinephrine versus placebo) \\
\hline Flores-González 2016 & Other comparison (epinephrine versus placebo) \\
\hline Guomo 2007 & Abstract available only \\
\hline Gupta 2016 & $\begin{array}{l}\text { Suspected plagiarism. This trial presented results identical to those of the Malik } 2015 \text { trial. We con- } \\
\text { tacted the first authors of both trials and the editors of the journals in which the trials were pub- } \\
\text { lished, but neither authors nor editors provided clarification. }\end{array}$ \\
\hline Kuzik 2010 & Inclusion of infants with previous history of wheezing \\
\hline Malik 2015 & $\begin{array}{l}\text { Suspected plagiarism. This trial presented results identical to those of the Gupta } 2016 \text { trial. We con- } \\
\text { tacted the first authors of both trials and the editors of the journals in which the trials were pub- } \\
\text { lished, but neither authors nor editors provided clarification. }\end{array}$ \\
\hline Nenna 2014 & Other comparison (hypertonic saline $+0.1 \%$ hyaluronic acid versus $0.9 \%$ saline) \\
\hline Silver 2015 & Inclusion of infants with previous history of wheezing \\
\hline Tribastone 2003 & Not an RCT (summary of Sarrell 2002) \\
\hline
\end{tabular}

$\mathrm{RCT}$ : randomised controlled trial

Characteristics of studies awaiting assessment [ordered by study ID]

CTRI/2010/091/003065

\begin{tabular}{ll}
\hline Methods & Randomised, double-blind, parallel-group, controlled trial \\
\hline Participants & $\begin{array}{l}\text { Consecutive patients with moderate to severe bronchiolitis, aged } 2 \text { months to } 2 \text { years, of either sex, } \\
\text { admitted to the hospital during the study period }\end{array}$ \\
\hline Interventions & Nebulised hypertonic saline versus nebulised normal saline \\
\hline Outcomes & Primary outcome: \\
& $\begin{array}{l}\text { Length of hospital stay (the time between study entry and the time at which the infant reached pro- } \\
\text { tocol-defined discharge criteria as measured by study physician) } \\
\text { Secondary outcomes: }\end{array}$ \\
\hline
\end{tabular}


Change in oxygen saturation (pulse oximetry)

Notes
Completion of data collection: February 2013
Last updated: 3 April 2017
Contact information: Lopamudra Mishra, 27A South Sinthee Road Kolkata 700050 Kolkata, West
Bengal, India; email: lopamudra83.cmc@gmail.com

EudraCT2009-014758-14

\begin{tabular}{ll}
\hline Methods & Randomised, double-blind, parallel-group, controlled trial \\
\hline Participants & Infants under the age of 12 months with a clinical diagnosis of bronchiolitis \\
\hline Interventions & Nebulised $3 \%$ hypertonic saline plus salbutamol \\
\hline Outcomes & Primary outcomes: \\
& Duration of hospital stay \\
& Secondary outcomes: \\
& Duration of supplemental oxygen requirement \\
\hline Notes & Starting date: May 2010 \\
& Last updated: 19 March 2012 \\
\hline
\end{tabular}

\section{NCT00677729}

\begin{tabular}{ll}
\hline Methods & Randomised, double-blind, parallel-group, controlled trial \\
\hline Participants & $\begin{array}{l}\text { Infants aged up to } 24 \text { months, presenting to ED or outpatient department with moderately se- } \\
\text { vere viral bronchiolitis defined as history of viral upper respiratory tract infection within previous } 7 \\
\text { days, presence of wheezing or crackles, or both on chest auscultation, and RDAl score }>4 \text { (of } 17) \text { or } \\
\text { transcutaneous oxygen saturation }<94 \% \text { in room air }\end{array}$ \\
\hline Interventions & $\begin{array}{l}\text { Nebulised } 3 \% \text { hypertonic saline }(4 \mathrm{~mL}) \text { plus } 1.0 \mathrm{mg} \text { salbutamol versus nebulised } 0.9 \% \text { normal saline } \\
(4 \mathrm{~mL}) \text { plus } 1.0 \mathrm{mg} \text { salbutamol }\end{array}$ \\
& Study solutions were given every 20 minutes for a total of 3 doses.
\end{tabular}

Outcomes

Primary outcome: rate of admission to hospital 1 hour after treatment end

Secondary outcomes: change in the RDAl score between study entry and post-treatment

Notes Starting date: June 2008

Completion of data collection: April 2009

Last updated: November 2015 


\begin{tabular}{ll}
\hline Methods & Randomised, double-blind, parallel-group, controlled trial \\
\hline Participants & $\begin{array}{l}\text { Children aged } 6 \text { weeks to } 12 \text { months with first moderate-to-severe episode of acute viral bronchi- } \\
\text { olitis (history of viral upper respiratory tract infection plus wheezing or crackles, or both on chest } \\
\text { auscultation with respiratory distress), admitted in ED }\end{array}$ \\
\end{tabular}

2 doses of study solutions were given every 20 minutes.

\begin{tabular}{ll}
\hline Outcomes & Primary outcomes: \\
Admission rate at 24 hours \\
Secondary outcomes: \\
Change in RDAl score at 2 hours \\
Number of participants with adverse events at 2 hours \\
Length of hospitalisation for hospitalised infant \\
Health care utilisation within 1 month after discharge \\
\hline Starting date: October 2012 \\
Completion of data collection: April 2014 \\
Last updated: 25 July 2014 \\
Contact information: Vincent Gajdos, MD, PhD, Assistance Publique Hôpitaux de Paris - Paris Sud \\
Medical School
\end{tabular}

\begin{tabular}{|c|c|}
\hline Methods & Randomised, double-blind, parallel-group, controlled trial \\
\hline Participants & $\begin{array}{l}\text { Children under } 2 \text { years of age diagnosed with mild to moderate bronchiolitis, presenting to outpa- } \\
\text { tient Department of Hospital General Naval de Alta Especialidad, Mexico }\end{array}$ \\
\hline \multirow[t]{5}{*}{ Interventions } & Intervention 1: epinephrine and dexamethasone \\
\hline & $\begin{array}{l}1 \text { dose of nebulised dexamethasone }(4 \mathrm{mg}) \text { was given, followed by } 2 \text { doses of nebulised 1:1000 epi- } \\
\text { nephrine }(3 \mathrm{~mL} \text { ) at an interval of } 20 \text { minutes on the first day. Nebulised dexamethasone ( } 4 \mathrm{mg} \text { ) was } \\
\text { given every } 24 \text { hours for } 3 \text { days. }\end{array}$ \\
\hline & Intervention $2: 3 \%$ hypertonic saline \\
\hline & $\begin{array}{l}3 \text { doses of nebulised } 3 \% \text { saline }(4 \mathrm{~mL}) \text { were given every } 20 \text { minutes on the first day of treatment, fol- } \\
\text { lowed by nebulised } 3 \% \text { saline }(4 \mathrm{~mL}) \text { every } 24 \text { hours for } 3 \text { days }\end{array}$ \\
\hline & Active comparator: $0.9 \%$ normal saline \\
\hline
\end{tabular}


3 doses of nebulised $0.9 \%$ normal saline $(4 \mathrm{~mL})$ were given at an interval of 20 minutes on the first day of treatment, followed by nebulised $0.9 \%$ normal saline $(4 \mathrm{~mL})$ every 24 hours for 3 days

\begin{tabular}{ll}
\hline Outcomes & Primary outcome: \\
Rate of hospital admissions until 7 days after treatment \\
Secondary outcomes: \\
Number of participants with adverse events in each arm of treatment \\
Change from baseline CBSS after 3 treatments in the first day \\
Change from baseline heart rate after 3 treatments in the first day \\
Change from baseline oxygen saturation after 3 treatments in the first day \\
Starting date: January 2013 \\
Completion of data collection: June 2015 \\
Last updated: 4 July 2015 \\
Contact information: José Luis Rodríguez Cuevas, Hospital General Naval de Alta Especialidad, \\
México, Distrito Federal, Distrito Federal, Mexico 04480
\end{tabular}

\section{NCT02029040}

\begin{tabular}{ll}
\hline Methods & Randomised, double-blind, parallel-group, controlled trial \\
\hline Participants & $\begin{array}{l}\text { Children aged } 2 \text { to } 12 \text { months, presenting to ED with a diagnosis of bronchiolitis (RDAl score }=6) \\
\text { defined as the first episode of wheezing or crackles, or both in a child younger than } 12 \text { months } \\
\text { who has physical findings of a viral respiratory infection and there is no other explanation for the } \\
\text { wheezing and/or crackles }\end{array}$
\end{tabular}

Interventions $\quad$ Nebulised $3 \%$ hypertonic saline $(3 \mathrm{~mL})$ versus nebulised $0.9 \%$ normal saline $(3 \mathrm{~mL})$

A single dose of study solution was given.

\begin{tabular}{ll}
\hline Outcomes & $\begin{array}{l}\text { Primary outcomes: } \\
\text { Respiratory assessment change score (RACS) at } 15 \text { minutes and } 1 \text { hour } \\
\text { Secondary outcomes: } \\
\text { Rate of hospitalisations at } 24 \text { hours } \\
\text { Return to ED within } 7 \text { days following discharge }\end{array}$ \\
\hline Sotes & Completion of data collection: December 2014 \\
& Last updated: 3 May 2016 \\
Contact information: Mohamed Badawy, MD, University of Texas Southwestern Medical Center
\end{tabular}




\section{NCT02045238 (Continued)}

Participants
Children aged up to 12 months with clinical diagnosis of bronchiolitis (viral respiratory disease and first episode of wheezing) and with moderate respiratory distress, defined as having at least 2 of the following criteria: $\mathrm{SaO}_{2}<93 \%$, respiratory rate $>60$, and/or RDAl score $>4$

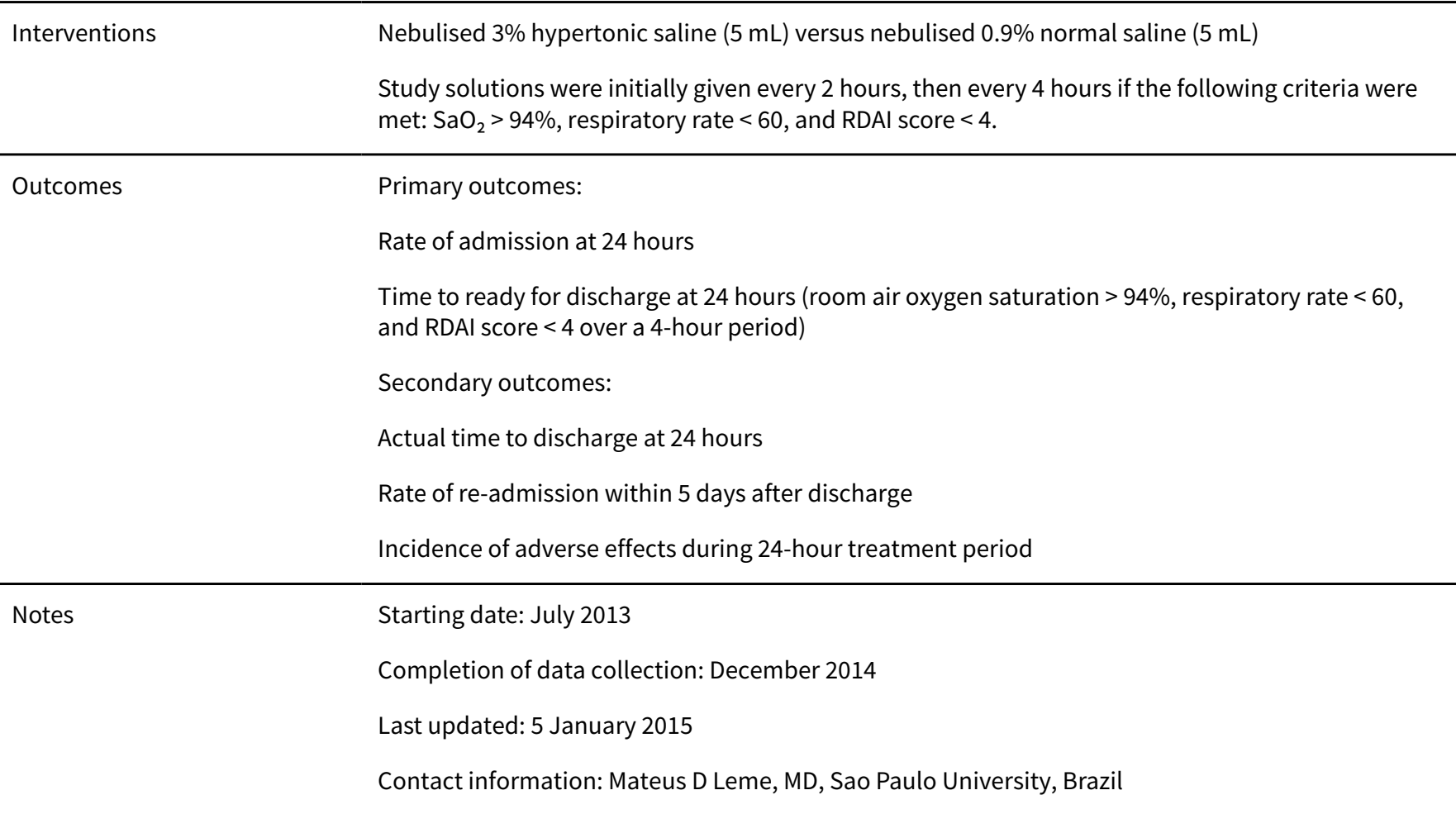

\section{NCT02233985}

\begin{tabular}{ll}
\hline Methods & Randomised, double-blind, parallel-group, controlled trial \\
\hline Participants & $\begin{array}{l}\text { Children aged } 2 \text { to } 24 \text { months attending the paediatric emergency service with moderate to severe } \\
\text { bronchiolitis, defined as first episode of wheezing associated with respiratory distress and a history } \\
\text { of upper respiratory tract infection }\end{array}$
\end{tabular}

Interventions

Nebulised 3\% hypertonic saline $(4 \mathrm{~mL})$ plus salbutamol $(100 \mathrm{mcg} / \mathrm{kg})$ versus nebulised $0.9 \%$ normal saline $(4 \mathrm{~mL})$ plus salbutamol $(100 \mathrm{mcg} / \mathrm{kg})$

3 doses of study solutions were initially given at an interval of 20 minutes, then every 4 hours during the entire hospital stay.

Outcomes

Primary outcomes:

Respiratory distress score (at baseline, 30 minutes after the end of the first 3 continuous nebulisation sessions, at 4 hours, 8 hours, and every 24 hours during the entire hospital stay)

Length of hospital stay (hours)

Secondary outcomes:

Hospital re-admission within 30 days after discharge

Frequency of complications within 30 days after discharge 
NCT02233985 (Continued)

Completion of data collection: April 2015

Last updated: 25 January 2017

Contact information: Gloria P Sosa-Bustamante, MD, Unidad Medica de Alta Especialidad Bajio 48. Hospital de Gineco - Pediatria, Instituto Mexicano del Seguro Social, Mexico

NCT02834819

\begin{tabular}{ll}
\hline Methods & Randomised, single-blind (investigator), parallel-group, controlled trial \\
\hline Participants & $\begin{array}{l}\text { Children aged } 3 \text { to } 18 \text { months, presenting to Children's Hospital Colorado Emergency Department } \\
\text { with diagnosis of bronchiolitis and persistent hypoxia following initial supportive care }\end{array}$
\end{tabular}

Interventions

Nebulised $3 \%$ hypertonic saline $(4 \mathrm{~mL})$ plus standard care versus standard care alone

A single dose of study solution was given.

\section{Outcomes}

\section{Primary outcomes:}

Hospitalisation rate at any point during enrolment visit or up to 7 days after enrolment visit

Need for supplemental oxygen at time of hospital discharge for up to 7 days

Persistent hypoxia at baseline and 90 minutes postintervention

Secondary outcomes:

Adverse outcomes during enrolment visit or within 7 days following enrolment visit

Hospital admission within 7 days following discharge from enrolment visit

Postintervention clinical severity score during enrolment visit - 90 minutes after randomisation

Pre-intervention clinical severity score during enrolment visit following randomisation

Unscheduled return ED visits 7 days post-enrolment visit

Starting date: September 2013
Completion of data collection: September 2015
Last updated: 14 July 2016
Contact information: Cortney Braund, MD, University of Colorado, Denver

CBSS: Clinical Bronchiolitis Severity Score

ED: emergency department

RDAl: Respiratory Distress Assessment Instrument

$\mathrm{SaO}_{2}$ : oxygen saturation

\section{DATA AND ANALYSES}


Comparison 1. Hypertonic saline versus normal saline $(0.9 \%)$

\begin{tabular}{|c|c|c|c|c|}
\hline Outcome or subgroup title & No. of studies & $\begin{array}{l}\text { No. of partici- } \\
\text { pants }\end{array}$ & Statistical method & Effect size \\
\hline $\begin{array}{l}1 \text { Length of hospital stay } \\
\text { (days) }\end{array}$ & 17 & 1867 & $\begin{array}{l}\text { Mean Difference (IV, Random, 95\% } \\
\mathrm{CI})\end{array}$ & $-0.41[-0.75,-0.07]$ \\
\hline 2 Rate of hospitalisation & 8 & 1723 & Risk Ratio (M-H, Random, 95\% Cl) & $0.86[0.76,0.98]$ \\
\hline $\begin{array}{l}3 \text { Clinical severity score } \\
\text { (post-treatment) at day } 1\end{array}$ & 9 & 812 & $\begin{array}{l}\text { Mean Difference (IV, Random, 95\% } \\
\mathrm{CI})\end{array}$ & $-0.77[-1.18,-0.36]$ \\
\hline 3.1 Outpatients & 1 & 65 & $\begin{array}{l}\text { Mean Difference (IV, Random, 95\% } \\
\mathrm{CI})\end{array}$ & $-1.28[-1.92,-0.64]$ \\
\hline $\begin{array}{l}\text { 3.2 Emergency department } \\
\text { patients }\end{array}$ & 1 & 171 & $\begin{array}{l}\text { Mean Difference (IV, Random, 95\% } \\
\mathrm{CI})\end{array}$ & $-0.09[-0.51,0.33]$ \\
\hline 3.3 Inpatients & 7 & 576 & $\begin{array}{l}\text { Mean Difference (IV, Random, 95\% } \\
\mathrm{CI})\end{array}$ & $-0.82[-1.25,-0.38]$ \\
\hline $\begin{array}{l}4 \text { Clinical severity score } \\
\text { (post-treatment) at day } 2\end{array}$ & 8 & 703 & $\begin{array}{l}\text { Mean Difference (IV, Random, 95\% } \\
\mathrm{CI})\end{array}$ & $-1.28[-1.91,-0.65]$ \\
\hline 4.1 Outpatients & 1 & 65 & $\begin{array}{l}\text { Mean Difference (IV, Random, 95\% } \\
\mathrm{CI})\end{array}$ & $0.00[-2.93,-1.07]$ \\
\hline $\begin{array}{l}\text { 4.2 Emergency department } \\
\text { patients }\end{array}$ & 1 & 171 & $\begin{array}{l}\text { Mean Difference (IV, Random, 95\% } \\
\mathrm{CI})\end{array}$ & $-0.27[-0.63,0.09]$ \\
\hline 4.3 Inpatients & 6 & 467 & $\begin{array}{l}\text { Mean Difference (IV, Random, 95\% } \\
\mathrm{CI})\end{array}$ & $-1.39[-1.95,-0.84]$ \\
\hline $\begin{array}{l}5 \text { Clinical severity score } \\
\text { (post-treatment) at day } 3\end{array}$ & 7 & 499 & $\begin{array}{l}\text { Mean Difference (IV, Random, 95\% } \\
\mathrm{CI} \text { ) }\end{array}$ & $-1.43[-1.82,-1.04]$ \\
\hline 5.1 Outpatients & 1 & 65 & $\begin{array}{l}\text { Mean Difference (IV, Random, 95\% } \\
\mathrm{CI})\end{array}$ & $-2.64[-3.85,-1.43]$ \\
\hline 5.2 Inpatients & 6 & 434 & $\begin{array}{l}\text { Mean Difference (IV, Random, 95\% } \\
\text { Cl) }\end{array}$ & $-1.35[-1.72,-0.98]$ \\
\hline 6 Rate of re-admission & 6 & 787 & Risk Ratio (M-H, Random, 95\% Cl) & $0.77[0.48,1.25]$ \\
\hline $\begin{array}{l}7 \text { Time for resolution of } \\
\text { symptoms/signs }\end{array}$ & 2 & 615 & $\begin{array}{l}\text { Mean Difference (IV, Random, 95\% } \\
\mathrm{CI})\end{array}$ & $-1.19[-1.54,-0.84]$ \\
\hline 7.1 Wheezing & 2 & 205 & $\begin{array}{l}\text { Mean Difference (IV, Random, 95\% } \\
\mathrm{CI})\end{array}$ & $-1.16[-1.43,-0.89]$ \\
\hline 7.2 Cough & 2 & 205 & $\begin{array}{l}\text { Mean Difference (IV, Random, 95\% } \\
\mathrm{CI})\end{array}$ & $-1.01[-1.35,-0.66]$ \\
\hline $\begin{array}{l}7.3 \text { Pulmonary moist crack- } \\
\text { les }\end{array}$ & 2 & 205 & $\begin{array}{l}\text { Mean Difference (IV, Random, 95\% } \\
\mathrm{Cl} \text { ) }\end{array}$ & $-1.30[-2.28,-0.32]$ \\
\hline
\end{tabular}




\begin{tabular}{lllll}
\hline Outcome or subgroup title & No. of studies & $\begin{array}{l}\text { No. of partici- } \\
\text { pants }\end{array}$ & Statistical method & Effect size \\
\hline $\begin{array}{l}8 \text { Radiological assessment } \\
\text { score }\end{array}$ & 2 & 117 & $\begin{array}{l}\text { Mean Difference (IV, Random, 95\% } \\
\text { Cl) }\end{array}$ & $-0.08[-0.90,0.75]$ \\
\hline
\end{tabular}

\section{Analysis 1.1. Comparison 1 Hypertonic saline versus normal} saline $(0.9 \%)$, Outcome 1 Length of hospital stay (days).

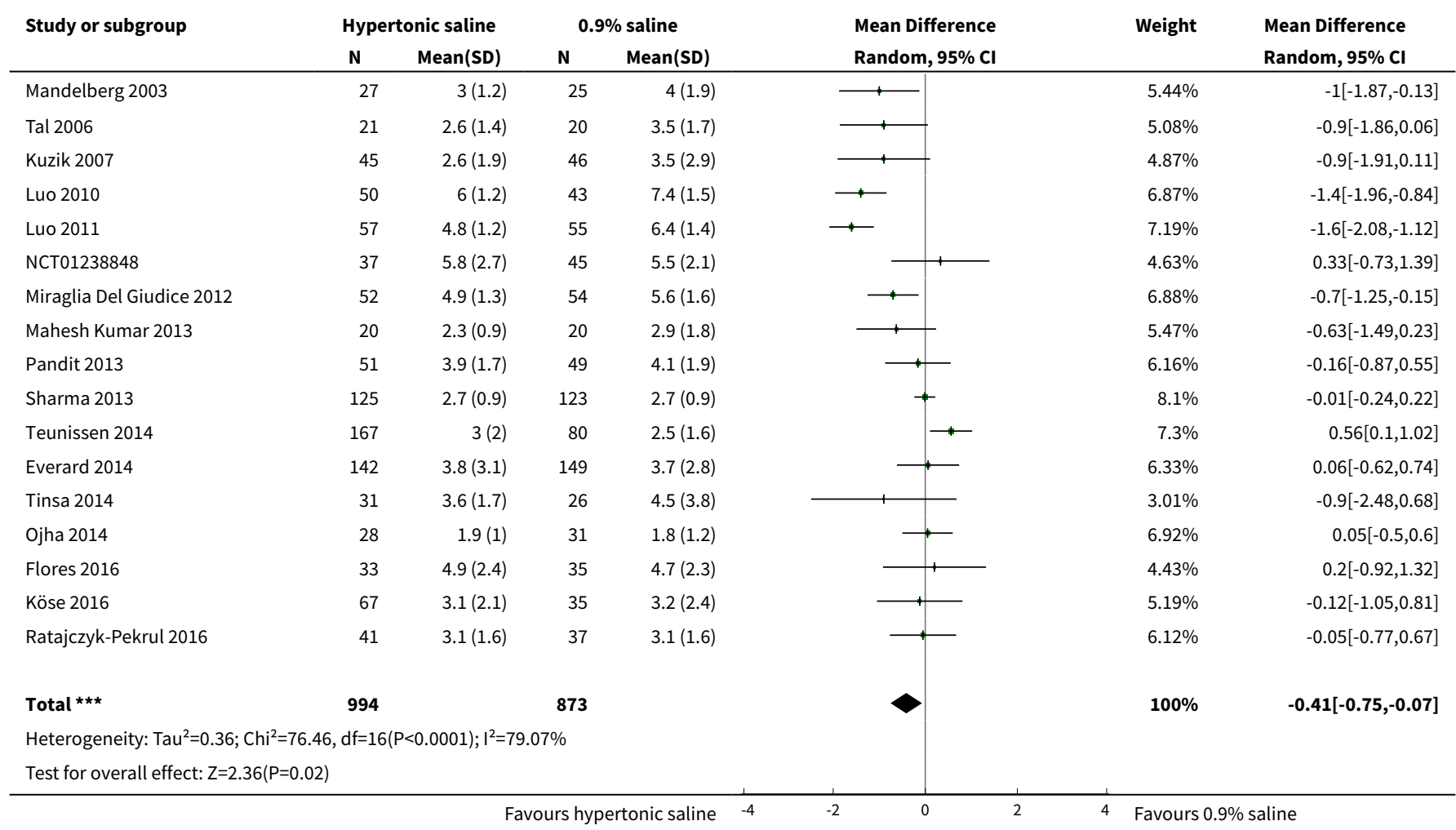

Analysis 1.2. Comparison 1 Hypertonic saline versus normal saline (0.9\%), Outcome 2 Rate of hospitalisation.

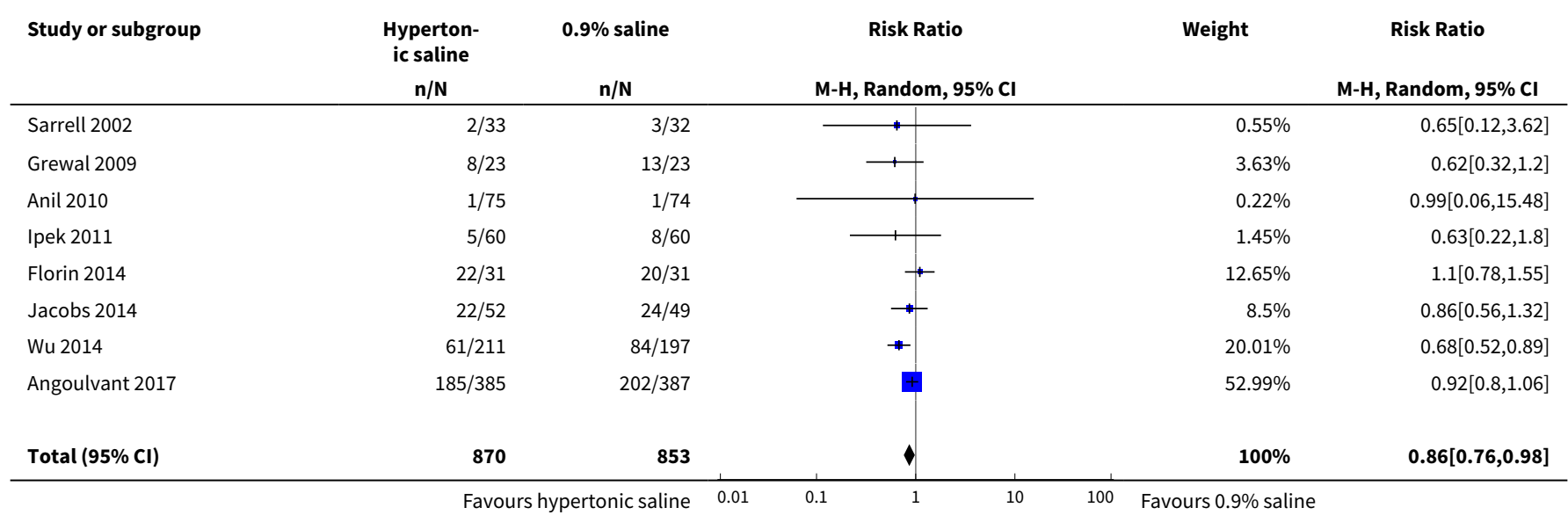




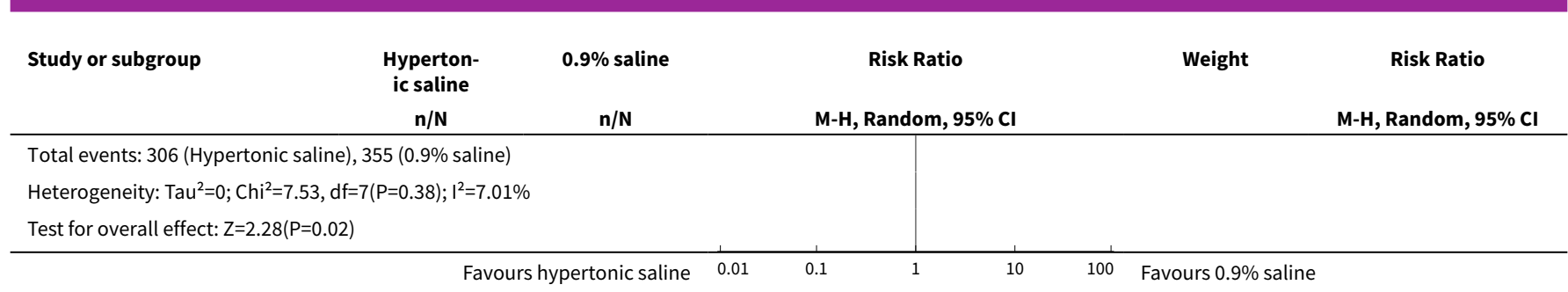

Analysis 1.3. Comparison 1 Hypertonic saline versus normal saline (0.9\%), Outcome 3 Clinical severity score (post-treatment) at day 1.

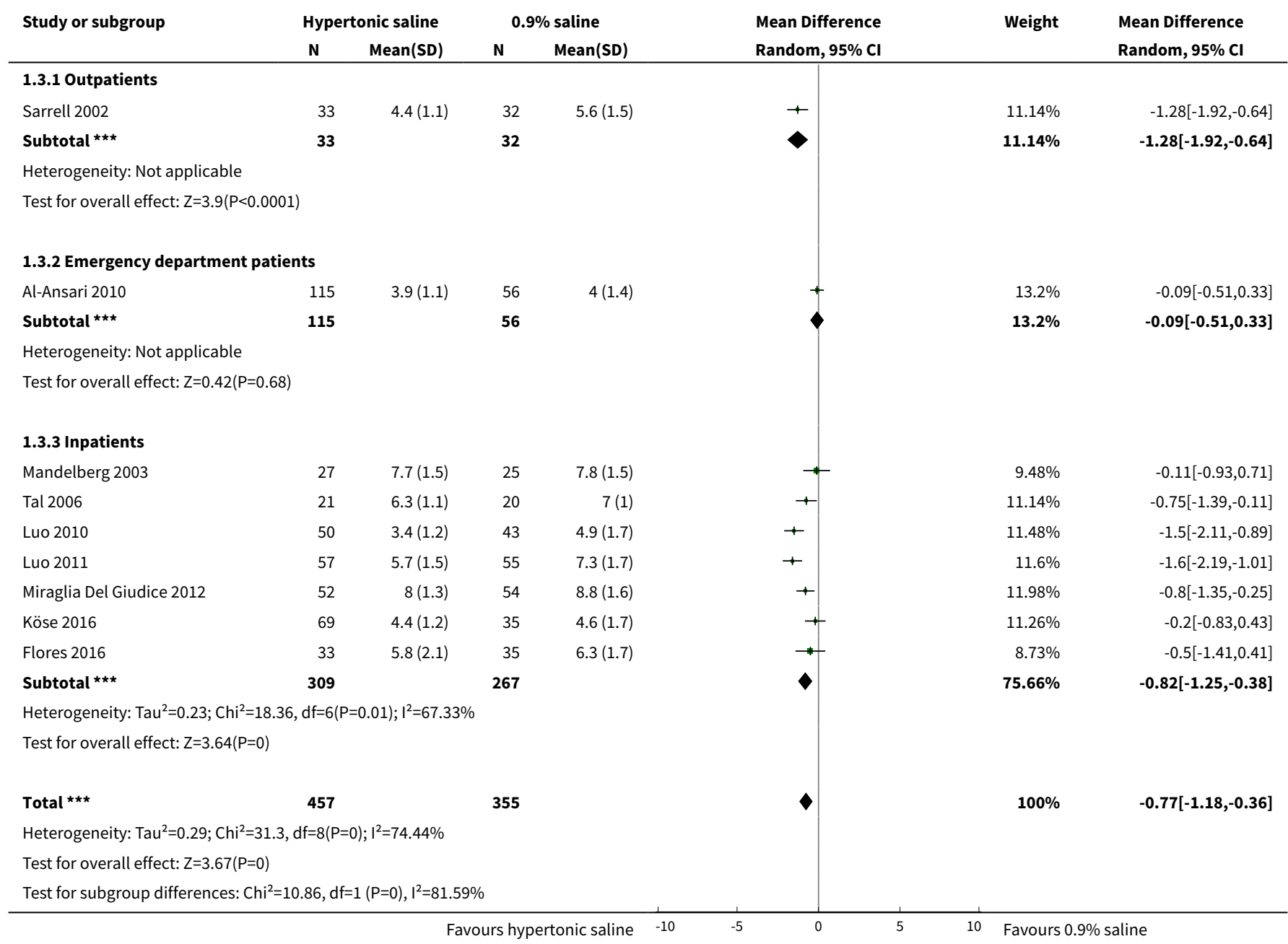

Analysis 1.4. Comparison 1 Hypertonic saline versus normal saline (0.9\%), Outcome 4 Clinical severity score (post-treatment) at day 2.

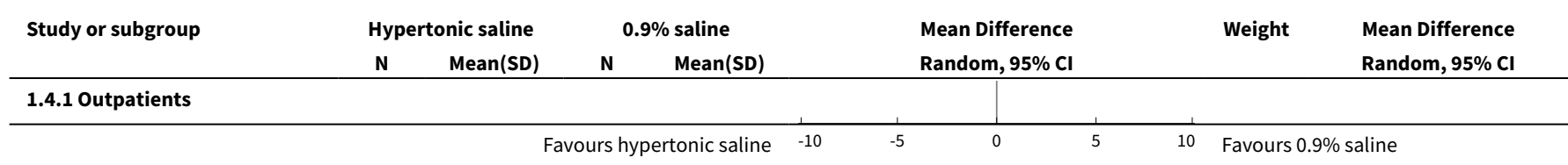




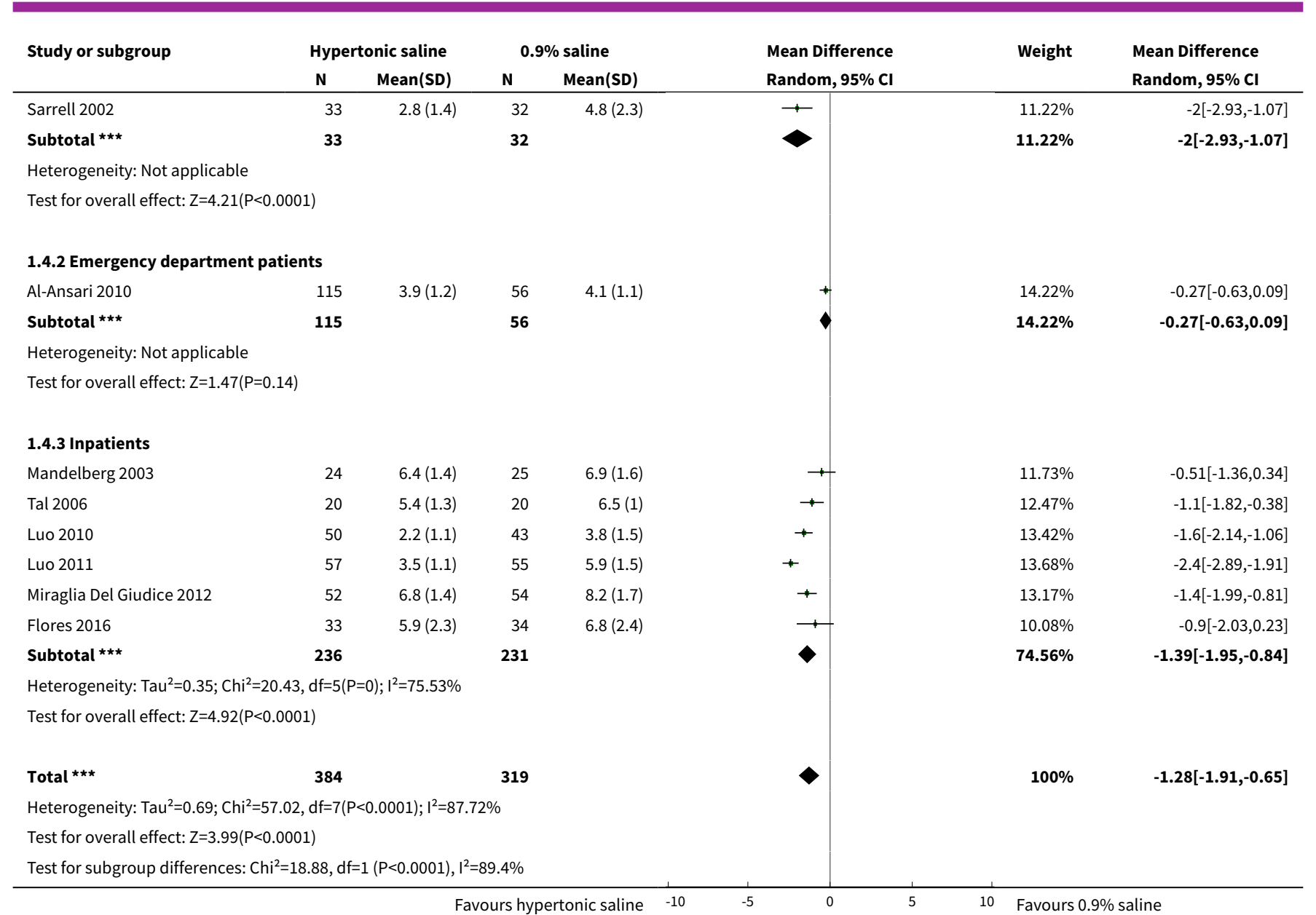

Analysis 1.5. Comparison 1 Hypertonic saline versus normal saline (0.9\%), Outcome 5 Clinical severity score (post-treatment) at day 3.

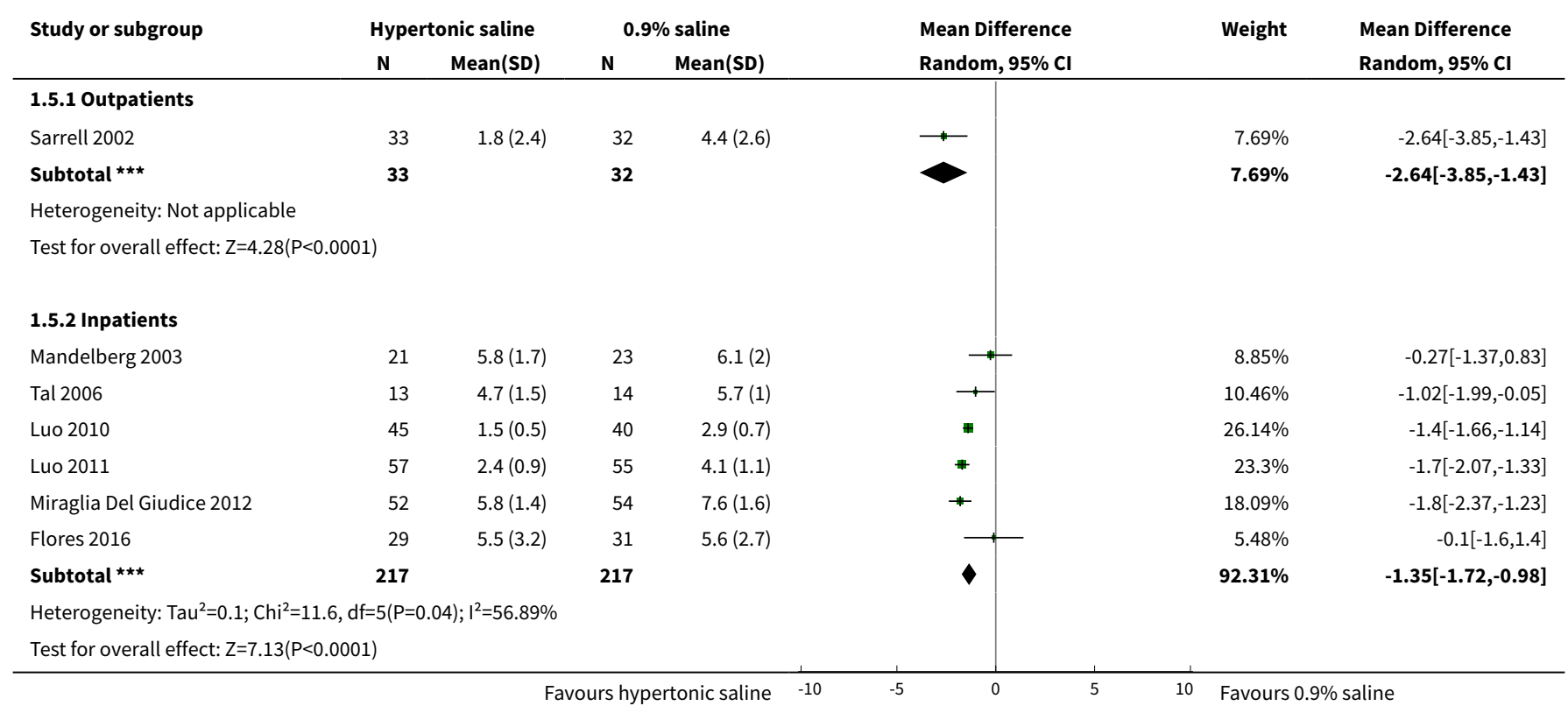




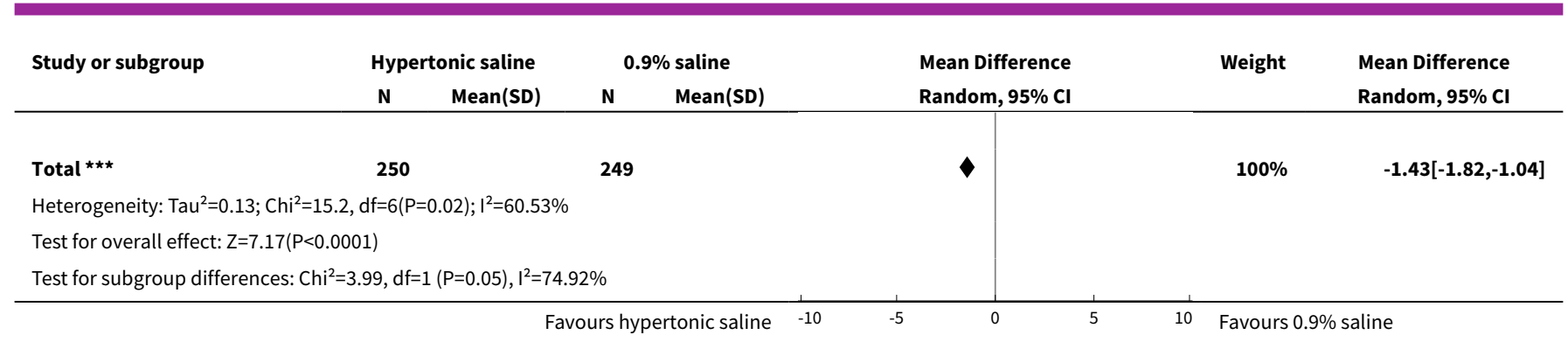

Analysis 1.6. Comparison 1 Hypertonic saline versus normal saline (0.9\%), Outcome 6 Rate of re-admission.

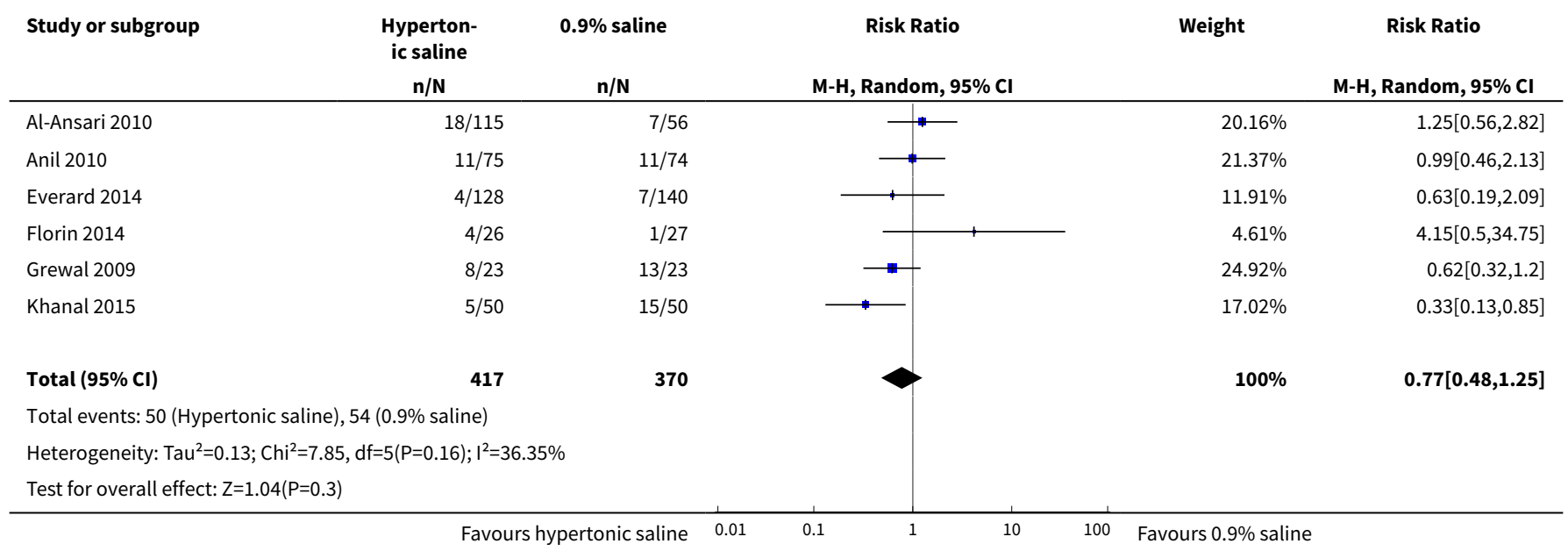

Analysis 1.7. Comparison 1 Hypertonic saline versus normal saline $(0.9 \%)$, Outcome 7 Time for resolution of symptoms/signs.

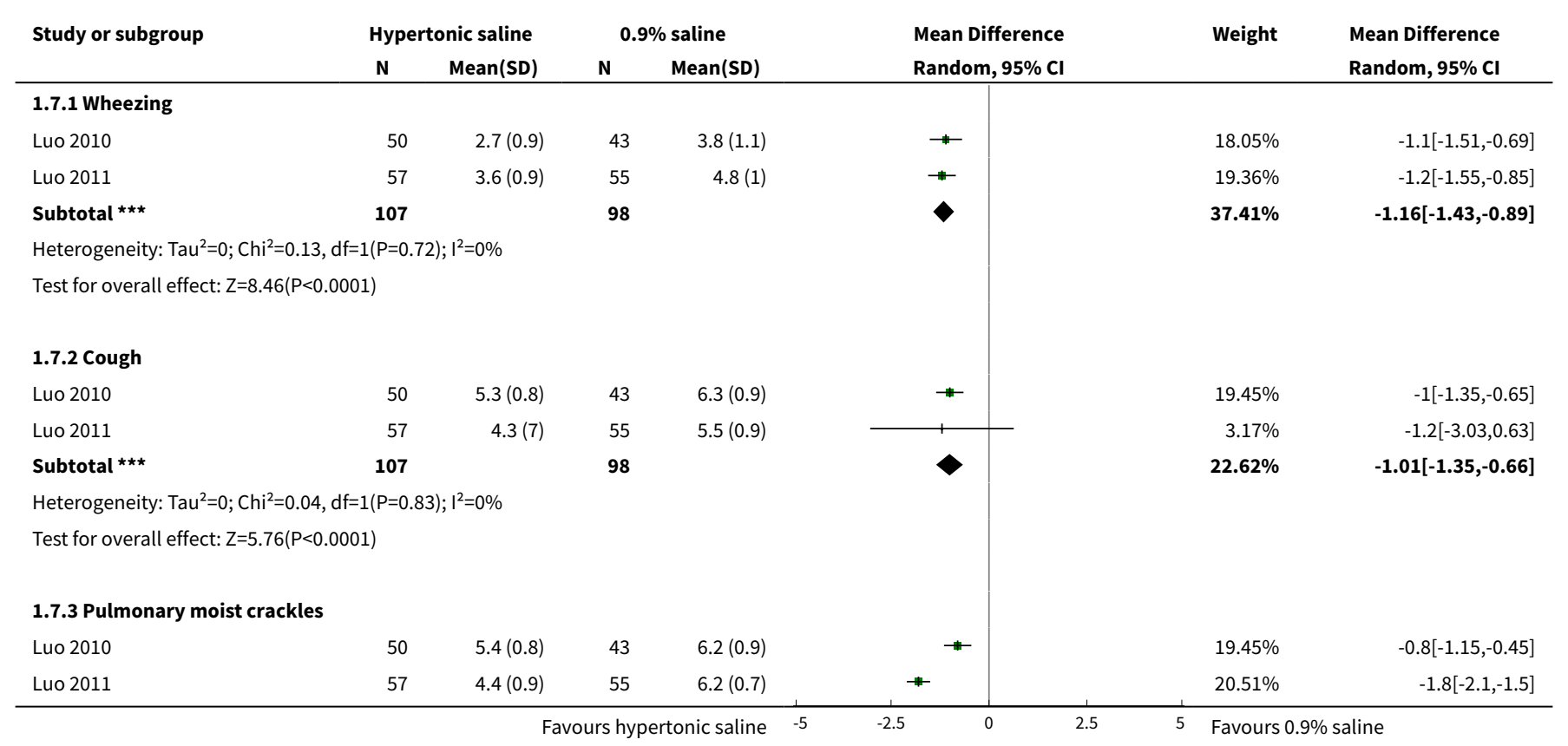




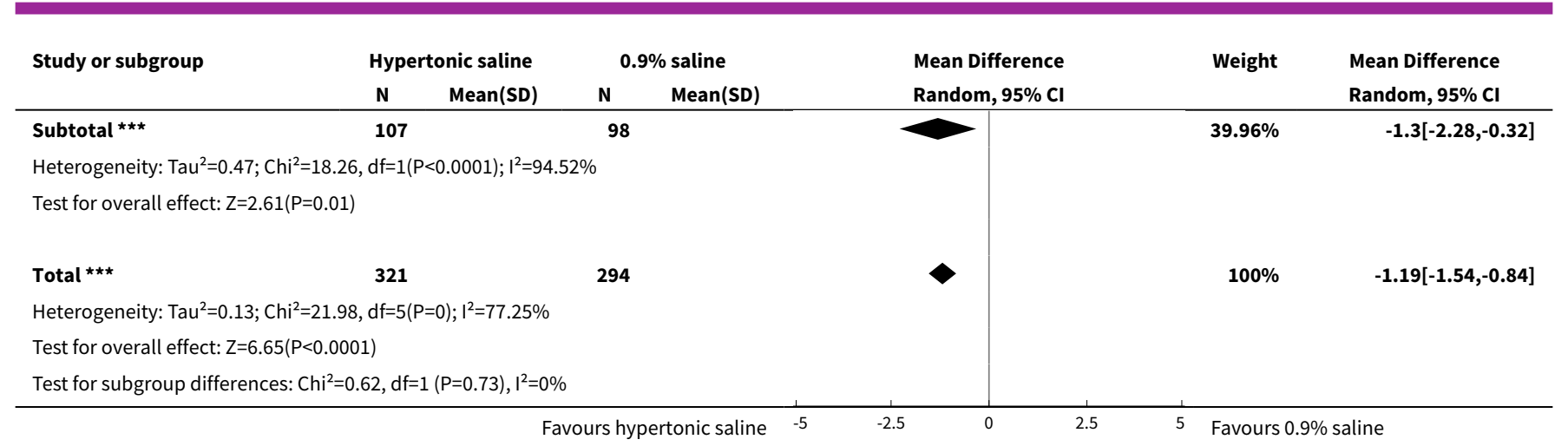

\section{Analysis 1.8. Comparison 1 Hypertonic saline versus normal saline $(0.9 \%)$, Outcome 8 Radiological assessment score.}

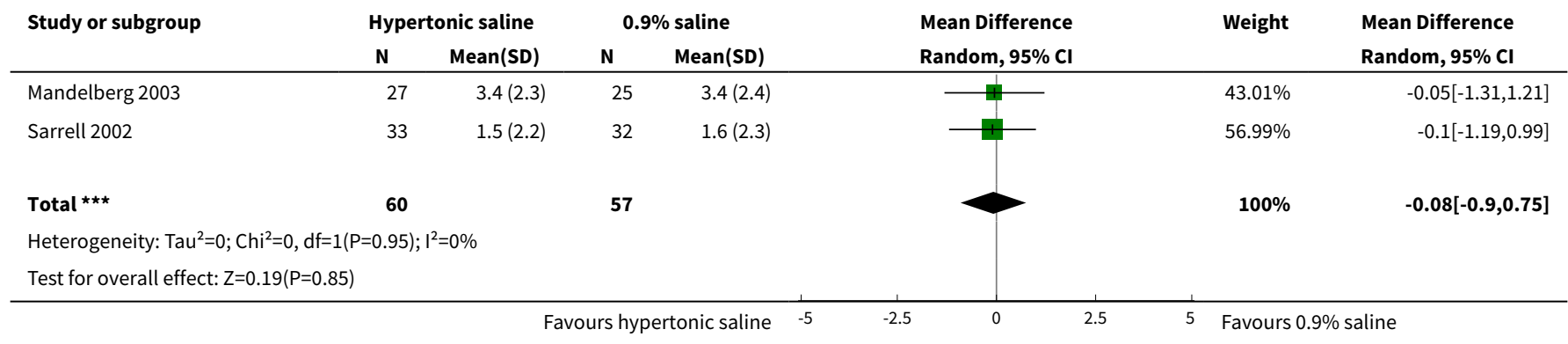

\section{ADDITIONAL TABLES}

Table 1. Treatment regimens of nebulised hypertonic saline

\begin{tabular}{llllll}
\hline Study ID & $\begin{array}{l}\text { Saline con- } \\
\text { centration }\end{array}$ & $\begin{array}{l}\text { Saline vol- } \\
\text { ume }\end{array}$ & $\begin{array}{l}\text { Bronchodilator ad- } \\
\text { ministered }\end{array}$ & Administration interval & Treatment duration
\end{tabular}

\section{Outpatient trials}

\begin{tabular}{llllll}
\hline Li 2014 & $3 \%, 5 \%$ & $3 \mathrm{~mL}$ & None & Twice daily & 3 days \\
\hline Sarrell 2002 & $3 \%$ & $2 \mathrm{~mL}$ & Terbutaline $5 \mathrm{mg}$ & Every 8 hours & 5 days \\
\hline
\end{tabular}

\section{Emergency department trials}

\begin{tabular}{|c|c|c|c|c|c|}
\hline Al-Ansari 2010 & $3 \%, 5 \%$ & $5 \mathrm{~mL}$ & Epinephrine $1.5 \mathrm{~mL}$ & Every 4 hours & Until discharge \\
\hline Anil 2010 & $3 \%$ & $4 \mathrm{~mL}$ & $\begin{array}{l}\text { Epinephrine } 1.5 \mathrm{~mL} \\
\text { or salbutamol } 2.5 \\
\mathrm{mg}\end{array}$ & Every 30 minutes & $\begin{array}{l}\text { Until } 2 \text { doses had } \\
\text { been administered }\end{array}$ \\
\hline Florin 2014 & $3 \%$ & $4 \mathrm{~mL}$ & None & $\begin{array}{l}\text { Within } 90 \text { minutes after al- } \\
\text { buterol administration }\end{array}$ & Single dose \\
\hline
\end{tabular}


Table 1. Treatment regimens of nebulised hypertonic saline (Continued)

$\begin{array}{llll}\text { Grewal } 2009 \quad 3 \% & 2.5 \mathrm{~mL} & \begin{array}{l}2.25 \% \text { racemic epi- } \\ \text { nephrine } 0.5 \mathrm{~mL}\end{array} & \begin{array}{l}\text { If needed, the second dose was } \\ \text { given during the 120-minute } \\ \text { study period. }\end{array}\end{array}$ Up to 2 doses

\begin{tabular}{|c|c|c|c|c|c|}
\hline Ipek 2011 & $3 \%$ & $4 \mathrm{~mL}$ & $\begin{array}{l}\text { Salbutamol } 0.15 \\
\mathrm{mg} / \mathrm{kg}\end{array}$ & Every 20 minutes & $\begin{array}{l}\text { Until } 3 \text { doses had } \\
\text { been administered }\end{array}$ \\
\hline Jacobs 2014 & $7 \%$ & $3 \mathrm{~mL}$ & $\begin{array}{l}\text { Racemic epineph- } \\
\text { rine } 0.5 \mathrm{~mL}\end{array}$ & $\begin{array}{l}\text { Study solution was given af- } \\
\text { ter initial screening and assess- } \\
\text { ment. }\end{array}$ & $\begin{array}{l}\text { Single dose (if the in- } \\
\text { fant was admitted, } \\
\text { the same solution } \\
\text { was given every } 6 \mathrm{~h} \\
\text { until discharge or } \\
24 \mathrm{~h} \text { after the admis- } \\
\text { sion). }\end{array}$ \\
\hline Khanal 2015 & $3 \%$ & $4 \mathrm{~mL}$ & Epinephrine $1.5 \mathrm{mg}$ & $\begin{array}{l}\text { Study solution was given at } 0 \\
\text { and } 30 \text { minutes. }\end{array}$ & $\begin{array}{l}\text { Until } 2 \text { doses had } \\
\text { been administered }\end{array}$ \\
\hline Wu 2014 & $3 \%$ & $4 \mathrm{~mL}$ & None & $\begin{array}{l}\text { Emergency department physi- } \\
\text { cians could order } 2 \text { additional } \\
\text { doses every } 20 \text { minutes. }\end{array}$ & Up to 3 doses \\
\hline $\begin{array}{l}\text { Angoulvant } \\
2017\end{array}$ & $3 \%$ & $4 \mathrm{~mL}$ & None & $\begin{array}{l}\text { Study solution was given at } 0 \\
\text { and } 30 \text { minutes. }\end{array}$ & $\begin{array}{l}\text { Until } 2 \text { doses had } \\
\text { been administered }\end{array}$ \\
\hline
\end{tabular}

\section{Inpatient trials}

\begin{tabular}{|c|c|c|c|c|c|}
\hline NCT01238848 & $3 \%$ & $3 \mathrm{~mL}$ & $\begin{array}{l}\text { Albuterol } 0.25 \mathrm{mg} / \\
\mathrm{kg} / \text { day }\end{array}$ & 4 times a day & 5 days \\
\hline Everard 2014 & $3 \%$ & $4 \mathrm{~mL}$ & None & Every 6 hours & Until fit for discharge \\
\hline Flores 2016 & $3 \%$ & $3 \mathrm{~mL}$ & $\begin{array}{l}\text { Salbutamol } 0.25 \mathrm{~mL} \\
(1.25 \mathrm{mg})\end{array}$ & Every 6 hours & Until discharge \\
\hline $\begin{array}{l}\text { Mahesh Ku- } \\
\text { mar } 2013\end{array}$ & $3 \%$ & $3 \mathrm{~mL}$ & $\begin{array}{l}\text { Salbutamol } 0.15 \\
\mathrm{mg} / \mathrm{kg}\end{array}$ & Every 6 hours & $\begin{array}{l}\text { Until ready for dis- } \\
\text { charge }\end{array}$ \\
\hline $\begin{array}{l}\text { Miraglia Del } \\
\text { Giudice } 2012\end{array}$ & $3 \%$ & $? \mathrm{~mL}$ & Epinephrine $1.5 \mathrm{mg}$ & Every 6 hours & Until discharge \\
\hline Köse 2016 & $3 \%, 7 \%$ & $2.5 \mathrm{~mL}$ & $\begin{array}{l}\text { Salbutamol } 0.15 \\
\mathrm{mg} / \mathrm{kg}\end{array}$ & $\begin{array}{l}2 \text { doses were given at } 30 \text {-minute } \\
\text { interval, followed by every } 6 \\
\text { hours. }\end{array}$ & Until discharge \\
\hline Kuzik 2007 & $3 \%$ & $4 \mathrm{~mL}$ & $\begin{array}{l}\text { Albuterol was } \\
\text { added in } 37 \% \text { of } \\
\text { the treatments, and } \\
\text { racemic epineph- } \\
\text { rine was added in } \\
23 \% \text { of the treat- } \\
\text { ments by attending } \\
\text { physicians. }\end{array}$ & $\begin{array}{l}\text { Every } 2 \text { hours for } 3 \text { doses, fol- } \\
\text { lowed by every } 4 \text { hours for } 5 \\
\text { doses, and then every } 6 \text { hours }\end{array}$ & Until discharge \\
\hline Luo 2010 & $3 \%$ & $4 \mathrm{~mL}$ & Salbutamol $2.5 \mathrm{mg}$ & Every 8 hours & Until discharge \\
\hline
\end{tabular}


Table 1. Treatment regimens of nebulised hypertonic saline (Continued)

\begin{tabular}{|c|c|c|c|c|c|}
\hline Luo 2011 & $3 \%$ & $4 \mathrm{~mL}$ & None & $\begin{array}{l}\text { Every } 2 \text { hours for } 3 \text { doses, fol- } \\
\text { lowed by every } 4 \text { hours for } 5 \\
\text { doses, and then every } 6 \text { hours }\end{array}$ & Until discharge \\
\hline $\begin{array}{l}\text { Mandelberg } \\
2003\end{array}$ & $3 \%$ & $4 \mathrm{~mL}$ & Epinephrine $1.5 \mathrm{mg}$ & Every 8 hours & Until discharge \\
\hline Sharma 2013 & $3 \%$ & $4 \mathrm{~mL}$ & Salbutamol $2.5 \mathrm{mg}$ & Every 4 hours & $\begin{array}{l}\text { Until ready for dis } \\
\text { charge }\end{array}$ \\
\hline Pandit 2013 & $3 \%$ & $4 \mathrm{~mL}$ & Epinephrine $1.0 \mathrm{~mL}$ & $\begin{array}{l}3 \text { doses were given at } 1 \text {-hour } \\
\text { intervals, followed by every } 6 \\
\text { hours. }\end{array}$ & Until discharge \\
\hline Ojha 2014 & $3 \%$ & $4 \mathrm{~mL}$ & None & Every 8 hours & Until discharge \\
\hline $\begin{array}{l}\text { Rata- } \\
\text { jczyk-Pekrul } \\
2016\end{array}$ & $3 \%$ & $3 \mathrm{~mL}$ & $\begin{array}{l}\text { Salbutamol } 0.15 \\
\mathrm{mg} / \mathrm{kg}\end{array}$ & Every 4 hours & Until discharge \\
\hline Tal 2006 & $3 \%$ & $4 \mathrm{~mL}$ & Epinephrine $1.5 \mathrm{mg}$ & Every 8 hours & Until discharge \\
\hline $\begin{array}{l}\text { Teunissen } \\
2014\end{array}$ & $3 \%, 6 \%$ & $4 \mathrm{~mL}$ & Salbutamol $2.5 \mathrm{mg}$ & Every 8 hours & Until discharge \\
\hline Tinsa 2014 & $5 \%$ & $4 \mathrm{~mL}$ & Epinephrine $2 \mathrm{~mL}$ & Every 4 hours & Until discharge \\
\hline
\end{tabular}

Table 2. Subgroup analyses on length of hospital stay among inpatients

\begin{tabular}{|c|c|c|c|c|c|}
\hline \multirow[t]{2}{*}{ Subgroups } & \multicolumn{5}{|c|}{ Length of hospital stay (days) } \\
\hline & Trial (n) & $\begin{array}{l}\text { Participants } \\
\text { (N) }\end{array}$ & Effect size (MD, 95\% Cl) & P values & $\begin{array}{l}\text { Heterogene- } \\
\text { ity }\left(I^{2}\right)\end{array}$ \\
\hline \multicolumn{6}{|c|}{ Virological investigation } \\
\hline Available & 10 & 1179 & $-0.58(-1.12$ to -0.04$)$ & 0.03 & $84 \%$ \\
\hline Not available & 7 & 688 & $-0.05(-0.24$ to 0.13$)$ & 0.60 & $0 \%$ \\
\hline \multicolumn{6}{|c|}{ Upper age limits for infants } \\
\hline 12 months & 6 & 609 & $-0.37(-0.79$ to 0.04$)$ & 0.08 & $23 \%$ \\
\hline 18 to 24 months & 11 & 1258 & $-0.41(-0.86$ to 0.03$)$ & 0.07 & $86 \%$ \\
\hline \multicolumn{6}{|c|}{ Hypertonic saline solution plus bronchodilator } \\
\hline$\beta_{2}$ agonist & 9 & 1049 & $-0.22(-0.67$ to 0.22$)$ & 0.32 & $81 \%$ \\
\hline Epinephrine & 5 & 356 & $-0.65(-1.01$ to -0.30$)$ & $P<0.001$ & $0 \%$ \\
\hline No & 3 & 462 & $-0.51(-1.67$ to 0.65$)$ & 0.39 & $79 \%$ \\
\hline
\end{tabular}

\section{Administration interval *}


Table 2. Subgroup analyses on length of hospital stay among inpatients (Continued)

$\begin{array}{llllll}\text { A } & 12 & 1375 & -0.38(-0.77 \text { to } 0.002) & 0.05 & 75 \% \\ \text { B } & 5 & 492 & -0.51(-1.35 \text { to } 0.32) & 0.22 & 88 \%\end{array}$

\section{Hypertonic saline concentration}

\begin{tabular}{lllllll}
\hline $3 \%$ & 14 & 1461 & $-0.49(-0.86$ to -0.13$)$ & 0.01 & $52 \%$ & \\
$>3 \%$ & 3 & 406 & $0.09(-0.65$ to 0.85$)$ & 0.79 & $79 \%$ & \\
\hline
\end{tabular}

\section{Length of stay in the control group}

\begin{tabular}{llllll}
\hline$<3$ days & 4 & 594 & $0.07(-0.29$ to 0.44$)$ & 0.69 & $59 \%$ \\
$\geq 3$ days & 13 & 1273 & $-0.59(-0.97$ to -0.20$)$ & 0.003 & $68 \%$ \\
\hline
\end{tabular}

\section{Risk of selection bias}

\begin{tabular}{llllll}
\hline Low & 11 & 1366 & $-0.37(-0.81$ to 0.06$)$ & 0.09 & $82 \%$ \\
Unclear/high & 6 & 501 & $-0.51(-1.02$ to 0.004$)$ & 0.05 & $64 \%$
\end{tabular}

\section{Year of publication}

\begin{tabular}{llllll}
\hline Before 2013 & 7 & 577 & $-0.98(-1.41$ to -0.55$)$ & $P<0.001$ & $59 \%$ \\
$\begin{array}{l}2013 \text { and there- } \\
\text { after }\end{array}$ & 10 & 1290 & $0.02(-0.15$ to 0.20$)$ & 0.75 & $3 \%$ \\
\hline
\end{tabular}

Abbreviations: $\mathrm{Cl}$ : confidence interval; MD: mean difference

${ }^{\star} A$ : every 4 to 6 hours; B: every 8 hours

Table 3. Sensitivity analyses: length of hospital stay among inpatients

\begin{tabular}{llll}
\hline $\begin{array}{l}\text { Effect size } \\
(\mathbf{R R}, \mathbf{9 5} \% \mathbf{C l})\end{array}$ & $\begin{array}{l}\text { Heterogeneity } \\
\left(\mathbf{I}^{\mathbf{2}}\right)\end{array}$ & $\begin{array}{l}\text { Trials excluded from } \\
\text { analysis }\end{array}$ & Reasons for exclusion \\
\hline$-0.51(-0.91$ to -0.11$)$ & $82 \%$ & $\begin{array}{l}\text { NCT01238848; Everard } \\
2014 ; \text { Pandit 2013 }\end{array}$ & Open trials \\
\hline$-0.49(-0.83$ to -0.15$)$ & $75 \%$ & Teunissen 2014 & $\begin{array}{l}\text { Mean and standard deviation were estimated from } \\
\text { median and interquartile range. }\end{array}$ \\
\hline$-0.49(-0.87$ to -0.11$)$ & $80 \%$ & NCT01238848; Ojha 2014 & $\begin{array}{l}\text { Withdrawal rate }>15 \% \text { or data obtained from a part } \\
\text { of study sample. }\end{array}$ \\
\hline$-0.45(-0.78$ to -0.12$)$ & $80 \%$ & Everard 2014 & Did not use 0.9\% saline as the control \\
\hline$-0.22(-0.48$ to 0.05) & $50 \%$ & Luo 2010; Luo 2011; Ojha & $\begin{array}{l}\text { Very short (<2 days) or very long }>6 \text { days) length of } \\
\text { stay in the control group }\end{array}$
\end{tabular}

Abbreviations: $\mathrm{Cl}$ : confidence interval; RR: risk ratio 
Table 4. Subgroup analyses: hospitalisation rate among outpatients and emergency department patients

\section{Subgroups}

Hospitalisation rate (\%)

\begin{tabular}{|c|c|c|c|c|}
\hline Trial (n) & $\begin{array}{l}\text { Participants } \\
\text { (N) }\end{array}$ & $\begin{array}{l}\text { Effect size } \\
\text { (RR, 95\% Cl) }\end{array}$ & P values & $\begin{array}{l}\text { Heterogene- } \\
\text { ity } \\
\left(I^{2}\right)\end{array}$ \\
\hline
\end{tabular}

\section{Virological investigation}

\begin{tabular}{llllll}
\hline Available & 5 & 1392 & $0.81(0.69$ to 0.96$)$ & 0.01 & $21 \%$ \\
Not available & 3 & 331 & $1.04(0.75$ to 1.44$)$ & 0.81 & $0 \%$ \\
\hline
\end{tabular}

\section{Upper age limits for infants}

\begin{tabular}{llllll}
\hline 12 months & 2 & 818 & $0.86(0.64$ to 1.15$)$ & 0.31 & $26 \%$ \\
18 to 24 months & 6 & 905 & $0.82(0.66$ to 1.01$)$ & 0.06 & $9 \%$
\end{tabular}

\section{Hypertonic saline solution plus bronchodilator*}

\begin{tabular}{llllll}
\hline$\beta_{2}$ agonist & 3 & 257 & $0.65(0.28$ to 1.55$)$ & 0.34 & $0 \%$ \\
Epinephrine & 3 & 224 & $0.78(0.54$ to 1.12$)$ & 0.18 & $0 \%$ \\
No & 3 & 1242 & $0.87(0.68$ to 1.11$)$ & 0.27 & $65 \%$
\end{tabular}

\section{Administration interval ${ }^{\star \star}$}

\begin{tabular}{llllll}
\hline A & 3 & 209 & $0.91(0.67$ to 1.23$)$ & 0.54 & $24 \%$ \\
B & 5 & 1514 & $0.83(0.70$ to 0.98$)$ & 0.02 & $11 \%$ \\
\hline
\end{tabular}

\section{Hypertonic saline concentration}

\begin{tabular}{llllll}
\hline $3 \%$ & 7 & 1622 & $0.85(0.71$ to 1.00$)$ & 0.05 & $20 \%$ \\
$>3 \%$ & 1 & 101 & $0.86(0.56$ to 1.32$)$ & 0.50 & - \\
\hline
\end{tabular}

Risk of selection bias

\begin{tabular}{|c|c|c|c|c|c|}
\hline Low & 6 & 1454 & $0.85(0.72$ to 1.00$)$ & 0.06 & $29 \%$ \\
\hline Unclear/high & 2 & 269 & $0.66(0.24$ to 1.78$)$ & 0.42 & $0 \%$ \\
\hline \multicolumn{6}{|c|}{ Year of publication } \\
\hline Before 2013 & 4 & 380 & $0.63(0.37$ to 1.06$)$ & 0.08 & $0 \%$ \\
\hline $\begin{array}{l}2013 \text { and there- } \\
\text { after }\end{array}$ & 4 & 1343 & $0.87(0.72$ to 1.05$)$ & 0.15 & $48 \%$ \\
\hline
\end{tabular}

Abbreviations: $\mathrm{Cl}$ : confidence interval; RR: risk ratio

*Anil 2010 used two intervention groups: hypertonic saline plus salbutamol and hypertonic saline plus epinephrine.

${ }^{\star \star}$ Regimen A: single dose; regimen B: multiple doses $(\geq 2)$.

Table 5. Narrative summary: adverse events of treatment reported in 11 trials

Trials Comparisions Narrative summary




\title{
Table 5. Narrative summary: adverse events of treatment reported in $\mathbf{1 1}$ trials (Continued)
}

\begin{abstract}
Everard $2014 \quad 3 \%$ saline $(\mathrm{N}=142)$ versus standard care $(\mathrm{N}=$ 143)

6 AEs were possibly related to saline treatment, including $1 \mathrm{SAE}$, bradycardia and desaturation, which resolved the following day. The remaining 5 non-SAEs were: bradycardia (self correcting), desaturation, coughing fit, and increased respiratory rate (all of which were resolved within 1 day); and a chest infection, which resolved after 6 days.
\end{abstract}

\section{Flores 2016}

$3 \%$ saline + salbutamol

$(\mathrm{N}=33)$ versus $0.9 \%$

saline + salbutamol $(\mathrm{N}$

=35)

Exacerbation of coughing and excessive rhinorrhoea were more common in the $3 \%$ saline group $(45.5 \%$ and $57.6 \%$ ) than in the $0.9 \%$ saline group $(20 \%$ and $31.4 \%$ ). There was no significant difference in bronchial constriction and agitation between the 2 groups. Apnoea, cyanosis, saturation dips, tachycardia, and vomiting were not observed.

\begin{tabular}{ll}
\hline Grewal 2009 & $\begin{array}{l}\text { 3\% saline + epinephrine } \\
(\mathrm{N}=23) \text { versus } 0.9 \% \\
\text { saline }+ \text { epinephrine }(\mathrm{N} \\
=23)\end{array}$ \\
\hline
\end{tabular}

Adverse events were noted in 4 infants (vomiting 3; diarrhoea 1) in the hypertonic saline group. No additional bronchodilators were given to any enrolled infant during the study period.

Köse 2016 3\% saline + salbutamol
$(\mathrm{N}=35), 7 \%$ saline +
salbutamol $(\mathrm{N}=32)$ ver-
sus $0.9 \%$ saline + salbu-
tamol $(\mathrm{N}=35)$

No AEs were reported in the $3 \%$ and $0.9 \%$ saline groups. In the $7 \%$ saline group, bronchospasm was observed in 2 infants, and exacerbation of coughing was observed in another 2 infants. Both bronchospasm and cough was observed during nebulisation in 1 infant.

Kuzik $2007 \quad \begin{aligned} & 3 \% \text { saline }(\mathrm{N}=47) \text { ver- } \\ & \text { sus } 0.9 \% \text { saline }(\mathrm{N}=49)\end{aligned}$

No infants were withdrawn by the medical staff due to AEs, although 5 infants were withdrawn at parents' request due to perceived AEs, only 2 of which were from the hypertonic saline group (1 presented with vigorous crying and another with agitation).

\begin{tabular}{lll}
\hline Li 2014 & $\begin{array}{l}5 \% \text { saline }(\mathrm{N}=40), 3 \% \\
\text { saline }(\mathrm{N}=42) \text { versus } \\
0.9 \% \text { saline }(\mathrm{N}=42)\end{array}$ & $\begin{array}{l}\text { No AEs were observed in the 3\% and 0.9\% saline groups. } 4 \text { infants from the 5\% } \\
\text { saline group presented with paroxysmal cough during saline inhalation. }\end{array}$ \\
\hline Luo 2011 & $\begin{array}{l}\text { so saline }(\mathrm{N}=57) \text { ver- } \\
\text { sus 0.9\% saline }(\mathrm{N}=55)\end{array}$ & $\begin{array}{l}\text { No infants were withdrawn by the medical staff due to AEs. Coughing and } \\
\text { wheezing did not worsen during saline inhalation. Although } 5 \text { infants had } \\
\text { hoarse voices, only } 2 \text { of these were from the hypertonic saline group, and the } \\
\text { symptom disappeared after } 3 \text { to } 4 \text { days. }\end{array}$
\end{tabular}
symptom disappeared after 3 to 4 days.

\begin{tabular}{ll}
\hline Pandit 2013 & $\begin{array}{l}\text { 3\% saline + epinephrine } \\
(\mathrm{N}=51) \text { versus } 0.9 \% \\
\text { saline + epinephrine }(\mathrm{N} \\
=49)\end{array}$ \\
\hline Teunissen 2014 & $\begin{array}{l}3 \%, 6 \% \text { saline + salbu- } \\
\text { tamol ( } \mathrm{N}=167) \text { versus } \\
0.9 \% \text { saline }+ \text { salbuta- } \\
\text { mol ( } \mathrm{N}=80)\end{array}$ \\
\end{tabular}

No AEs were observed in the $3 \%$ saline group. In the $0.9 \%$ saline group, 3 in$(\mathrm{N}=51)$ versus $0.9 \% \quad$ fants had vomiting, and 1 infant had diarrhoea. saline + epinephrine ( $\mathrm{N}$ $3 \%, 6 \%$ saline + salbu$0.9 \%$ saline + salbuta$\mathrm{mol}(\mathrm{N}=80)$

\begin{abstract}
A substantial number of AEs (cough, bronchospasm, agitation, desaturation, etc.) were noted in all treatment groups. Except for cough, which occurred more significantly in the hypertonic saline groups $(P=0.03)$, no differences were found between groups. Withdrawals due to AEs did not differ between groups $(4.3 \%, 6.1 \%$, and $7.9 \%$ in the $3 \%, 6 \%$, and $0.9 \%$ saline groups, respectively; $P=0.59)$.
\end{abstract}

\section{Wu 2014}

$3 \%$ saline $(\mathrm{N}=211)$ versus $0.9 \%$ saline $(\mathrm{N}=$ 197)
3 infants in the normal saline group and 4 infants in the hypertonic saline group withdrew owing to parent request. Of these parent requests, 1 in the normal saline group and 2 in the hypertonic saline group were attributed to worsening cough. For these 3 infants, pre-treatment and post-treatment vital signs and Respiratory Distress Assessment Instrument score were the same or improved, and no intervention or additional treatment was necessary.
Angoulvant 2017
$3 \%$ saline $(\mathrm{N}=385)$ versus $0.9 \%$ saline $(\mathrm{N}=$ 387)
No SAEs were reported. Mild AEs occurred 57 times among 50 infants: in 35 of 392 infants ( $8.9 \%$ ) in the HS group versus 15 of 384 infants $(3.9 \%)$ in the NS group (risk difference $5.0 \%, 95 \%$ confidence interval $1.6 \%$ to $8.4 \% ; P=0.005$ ). 
Table 5. Narrative summary: adverse events of treatment reported in $\mathbf{1 1}$ trials (Continued)

Worsening of cough without respiratory distress was the most frequent $\mathrm{AE}$, occurring in 26 infants (6.6\%) in the HS group and 3 infants $(0.8 \%)$ in the NS group. Bronchospasm occurred in 3 infants $(0.8 \%)$ in the NS group.

Abbreviations:

AE: adverse event

HS: hypertonic saline

NS: normal saline

SAE: serious adverse event 


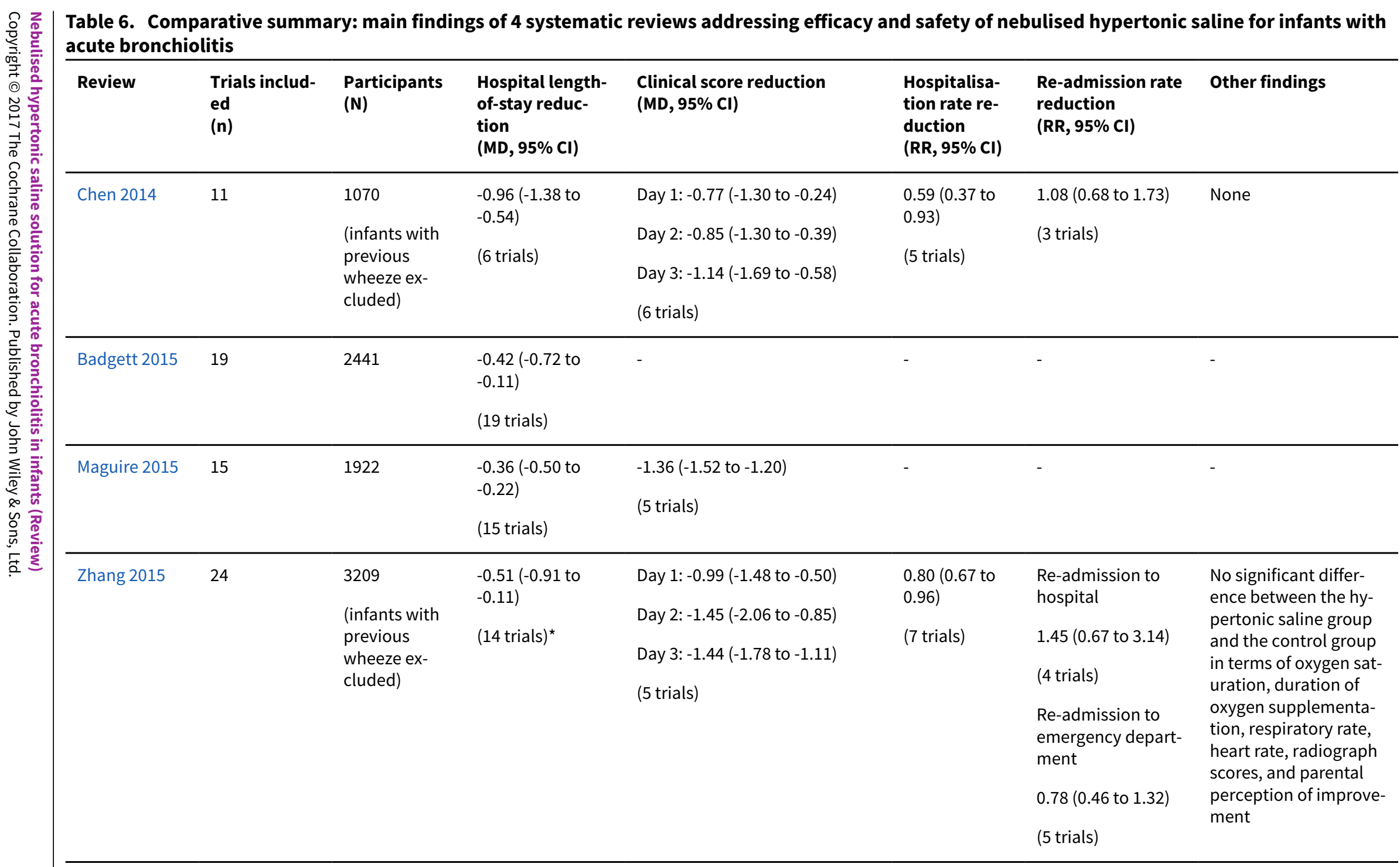

\section{Abbreviations: $\mathrm{Cl}$ : confidence interval; MD: mean difference; RR: risk ratio}

*Zhang 2015 included one unpublished inpatient trial (NCT01488448) that included infants with previous wheeze. In the erratum (Zhang 2016), removal of this trial from the metaanalysis changed the results of hypertonic saline on length of hospital stay from MD -0.45 days $(95 \% \mathrm{Cl}-0.82$ to -0.08$)$ to $\mathrm{MD}-0.51$ days $(95 \% \mathrm{Cl}-0.91$ to -0.11$)$. 


\section{AP PE N D I C E S}

\section{Appendix 1. Previous search}

For the 2013 update we searched the Cochrane Central Register of Controlled Trials (CENTRAL) 2013, Issue 4, part of The Cochrane Library, www.thecochranelibrary.com (accessed 8 May 2013), which contains the Cochrane Acute Respiratory Infections Group Specialised Register, MEDLINE (May 2010 to April week 4, 2013), EMBASE (June 2010 to April 2013) and LILACS (June 2010 to May 2013). We broadened our search to include two further databases and searched CINAHL (1981 to May 2013) and Web of Science (1955 to May 2013). We used the search strategy detailed in Appendix 2 to search MEDLINE and CENTRAL. As there were so few search results we used no filter to identify randomised trials in MEDLINE. We adapted the search terms to search EMBASE (Appendix 3), LILACS (Appendix 4), CINAHL (Appendix 5) and Web of Science (Appendix 6).

For the 2010 update we searched the Cochrane Central Register of Controlled Trials (CENTRAL) (The Cochrane Library 2010, Issue 2), which contains the Cochrane Acute Respiratory Infections Group Specialised Register, OLDMEDLINE (1951 to 1965), MEDLINE (1966 to May Week 4, 2010), EMBASE (1974 to June 2010) and LILACS (1985 to June 2010).

For the original search we searched the Cochrane Central Register of Controlled Trials (CENTRAL) (The Cochrane Library 2007, Issue 4), which contains the Cochrane Acute Respiratory Infections Group Specialised Register, OLDMEDLINE (1951 to 1965), MEDLINE (1966 to November 2007), EMBASE (1974 to November 2007) and LILACS (November 2007).

For the original search and the 2010 update the following search terms were combined with the highly sensitive search strategy as recommended by The Cochrane Collaboration (Dickersin 1994) to search MEDLINE. These terms were adapted to search CENTRAL, EMBASE and LILACS as required.

\section{MEDLINE (OVID)}

1 exp Bronchiolitis/

2 bronchiolit\$.mp.

3 exp Respiratory Syncytial Viruses/

4 exp Respiratory Syncytial Virus Infections/

5 (respiratory syncytial vir\$ or RSV).mp.

6 exp Parainfluenza Virus 1, Human/

7 exp Parainfluenza Virus 2, Human/

8 exp Parainfluenza Virus 3, Human/

9 exp Respirovirus Infections/

10 exp Adenoviridae Infections/

11 exp Influenza, Human/

12 (parainfluenza or adenovirus\$ or influenza).mp.

13 or $/ 1-12$

14 exp Saline Solution, Hypertonic/

15 hypertonic saline.mp.

16 exp Sodium Chloride/

17 saline.mp.

18 or/14-17

19 exp "Nebulizers and Vaporizers"/

20 (nebulis\$ or nebuliz\$).mp.

21 exp Administration, Inhalation/

22 inhal\$.mp.

23 exp Aerosols/

24 aerosol\$.mp.

25 or/ $19-24$

2613 and 18 and 25

27 from 26 keep 1-79

There were no language or publication restrictions.

\section{Appendix 2. MEDLINE (Ovid) search strategy}

1 exp Bronchiolitis/

2 (bronchiolit* $^{\star}$ or wheez $\left.{ }^{\star}\right)$.tw.

3 respiratory syncytial viruses/ or respiratory syncytial virus, human/

4 Respiratory Syncytial Virus Infections/

5 (respiratory syncytial virus* or rsv).tw. 
6 parainfluenza virus 1 , human/ or parainfluenza virus 3, human/

7 Parainfluenza Virus 2, Human/

8 Respirovirus Infections/

9 Adenovirus Infections, Human/

10 Rhinovirus/

11 Influenza, Human/

12 exp influenzavirus a/ or exp influenzavirus b/

13 (parainfluenza ${ }^{\star}$ or respirovirus ${ }^{\star}$ or adenovirus ${ }^{\star}$ or rhinovirus ${ }^{\star}$ or influenza*).tw.

14 or/1-13

15 Saline Solution, Hypertonic/

16 (hypertonic adj3 (saline or solution*)).tw.

17 Sodium Chloride/

18 (sodium chloride or saline).tw.

19 or/15-18

20 exp "Nebulizers and Vaporizers"/

21 (nebuli* or vapor* or vapour* or atomi*).tw.

22 Administration, Inhalation/

23 inhal $^{\star}$.tw.

24 Aerosols/

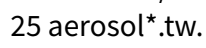

26 or/20-25

2714 and 19 and 26

\section{Appendix 3. Embase.com search strategy}

24. \#12 AND \#16 AND \#23

23. \#17 OR \#18 OR \#19 OR \#20 OR \#21 OR \#22

22. aerosol ${ }^{*}: a b, t i$

21. 'aerosol'/de

20. inhal ${ }^{*}: a b, t i$

19. 'inhalational drug administration'/de

18. nebuli*:ab,ti OR vapour*:ab,ti OR vapour*:ab,ti OR atomi*:ab,ti

17. 'nebulizer'/exp

16. \#13 OR \#14 OR \#15

15. 'sodium chloride':ab,ti OR saline:ab,ti

14. (hypertonic NEAR/3 (saline OR solution*)):ab,ti

13. 'hypertonic solution'/de OR 'sodium chloride'/de

12. \#1 OR \#2 OR \#3 OR \#4 OR \#5 OR \#6 OR \#7 OR \#8 OR \#9 OR \#10 OR \#11

11. parainfluenza*:ab,ti OR respirovirus* $:$ ab,ti OR adenovirus ${ }^{\star}: a b$, ti OR rhinovirus ${ }^{*}: a b$, ti OR

influenza*:ab,ti

10. 'influenza virus'/de OR 'influenza virus a'/exp OR 'influenza virus b'/de OR 'influenza'/exp

9. 'rhinovirus infection'/de

8. 'human adenovirus infection'/de

7. 'respirovirus infection'/de

6. 'parainfluenza virus 1 '/de OR 'parainfluenza virus 2 '/de OR 'parainfluenza virus 3 '/de

5. 'respiratory syncytial virus':ab,ti OR 'respiratory syncytial viruses':ab,ti OR rsv:ab,ti

4. 'respiratory syncytial virus infection'/de

3. 'respiratory syncytial pneumovirus'/de

2. bronchiolit*:ab,ti

1. 'bronchiolitis'/exp

\section{Appendix 4. LILACS search strategy}

> Search > (MH:Bronchiolitis OR bronchiolit\$ OR Bronquiolitis OR Bronquiolite OR MH:C08.127.446.135\$ OR MH:C08.381.495.146.135\$ OR MH:C08.730.099.135\$ OR wheez\$ OR MH:"Respiratory Syncytial Viruses" OR "Virus Sincitiales Respiratorios" OR "Vírus Sinciciais Respiratórios" OR "Respiratory Syncytial Virus, Human" OR "Respiratory Syncytial Virus Infections" OR "Infecciones por Virus Sincitial Respiratorio" OR "Infecções por Vírus Respiratório Sincicial" OR rsv "respiratory syncytial virus" OR "respiratory syncytial virus infection" OR "respiratory syncytial virus infections") AND (MH:"Saline Solution, Hypertonic" OR "Solución Salina Hipertónica" OR "Solução Salina Hipertônica" OR "Hypertonic Saline Solution" OR "Solución Hipertónica de Cloruro de Sodio" OR "Solução Salina Hipertônica" OR "Solução Hipertônica de Cloreto de Sódio" OR MH:"Sodium Chloride" OR "sodium chloride" OR "Cloruro de Sodio" OR "Cloreto de Sódio" OR salin\$) AND (MH:"Nebulizers and Vaporizers" OR MH:E07.605\$ OR atomi\$ OR inhal\$ OR vapor\$ OR vapour\$ OR nebuli\$ OR Inala\$ OR MH:Aerosols OR aerosol\$ OR Aerossóis OR MH:"Administration, Inhalation" OR "Administración por Inhalación" OR "Administração por Inalação") 


\section{Appendix 5. CINAHL (EBSCO) search strategy}

S22 S10 and S15 and S21

$\mathrm{S} 21 \mathrm{~S} 16$ or $\mathrm{S} 17$ or $\mathrm{S} 18$ or $\mathrm{S} 19$ or S20

S20 TI (inhal* or aerosol*) OR AB (inhal* or aerosol*)

S19 (MH "Aerosols")

S18 (MH "Administration, Inhalation")

S17 TI (nebuli* or vapor ${ }^{\star}$ or vapour ${ }^{\star}$ or atomi ${ }^{\star}$ ) OR AB (nebuli* or vapor $^{\star}$ or vapour $^{\star}$ or atomi ${ }^{\star}$ )

S16 (MH "Nebulizers and Vaporizers")

$\mathrm{S} 15 \mathrm{~S} 11$ or $\mathrm{S} 12$ or $\mathrm{S} 13$ or $\mathrm{S} 14$

$\mathrm{S} 14 \mathrm{TI}$ (sodium chloride or saline) OR AB (sodium chloride or saline)

S13 (MH "Sodium Chloride")

S12 TI (hypertonic N3 (salin* or solut $\left.{ }^{\star}\right)$ ) OR AB (hypertonic N3 (salin* or solut $\left.{ }^{\star}\right)$ )

S11 (MH "Saline Solution, Hypertonic")

$\mathrm{S} 10 \mathrm{~S} 1$ or S2 or S3 or S4 or S5 or S6 or S7 or S8 or S9

S9 TI (influenza* or flu) OR AB (influenza* or flu)

S8 (MH "Influenzavirus A+") OR (MH "Influenzavirus B+")

S7 (MH "Influenza") OR (MH "Influenza, Human") OR (MH "Influenza A H5N1") OR (MH "Influenza, Pandemic (H1N1) 2009") OR (MH "Influenza, Seasonal")

S6 TI (parainfluenza* or respirovirus* or adenovirus ${ }^{\star}$ or rhinovirus ${ }^{\star}$ ) OR AB (parainfluenza* or respirovirus ${ }^{\star}$ or adenovirus ${ }^{\star}$ or rhinovirus $^{\star}$ ) S5 TI (respiratory syncytial virus* or rsv) OR AB (respiratory syncytial virus* or rsv)

S4 (MH "Respiratory Syncytial Virus Infections")

S3 (MH "Respiratory Syncytial Viruses")

S2 TI (bronchiolit* or wheez ${ }^{\star}$ ) OR AB (bronchiolit* or wheez*)

S1 (MH "Bronchiolitis+")

\section{Appendix 6. Web of Science (Thomson Reuters) search strategy}

\begin{tabular}{|l|l|}
\hline$\# 3$ & 93 \\
\hline & \\
\hline$\# 2$ & $1,322,438$ \\
\hline & \\
\hline$\# 1$ & 173 \\
\hline
\end{tabular}

WHAT'S NEW

\begin{tabular}{lll}
\hline Date & Event & Description \\
\hline 11 August 2017 & New search has been performed & $\begin{array}{l}\text { We conducted updated searching and new analyses. We creat- } \\
\text { ed and examined a funnel plot to explore possible small-study } \\
\text { effects and publication bias. We revised the review text. We in- } \\
\text { cluded 17 new trials in this updated review (Angoulvant 2017; }\end{array}$ \\
& NCT01238848; Everard 2014; Flores 2016; Florin 2014; Jacobs \\
& 2014; Khanal 2015; Köse 2016; Li 2014; Mahesh Kumar 2013; Ojha \\
& 2014; Pandit 2013; Ratajczyk-Pekrul 2016; Sharma 2013; Teu- \\
& nissen 2014; Tinsa 2014; Wu 2014). We excluded nine new tri- \\
& als (Al-bahadily 2017; Bagus 2012; Bueno Campaña 2014; Flo- \\
& res-González 2015; Flores-González 2016; Gupta 2016; Malik \\
& 2015; Nenna 2014; Silver 2015). Nine studies await classification \\
& (CTRI/2010/091/003065; EudraCT2009-014758-14; NCT00677729; \\
& NCT01777347; NCT01834820; NCT02029040; NCT02045238;
\end{tabular}




\begin{tabular}{lll}
\hline Date & Event & Description \\
\hline & & $\begin{array}{l}\text { NCT02233985; NCT02834819). We conducted additional post hoc } \\
\text { subgroup, sensitivity, and meta-regression analyses. }\end{array}$ \\
\hline 11 August 2017 & $\begin{array}{l}\text { New citation required and conclusions } \\
\text { have changed }\end{array}$ & $\begin{array}{l}\text { Nebulised hypertonic saline may modestly reduce the length of } \\
\text { hospital stay among infants hospitalised with acute bronchiolitis } \\
\text { and improve clinical severity score. Nebulised hypertonic saline } \\
\text { may also reduce the risk of hospitalisation among outpatients } \\
\text { and emergency department patients. }\end{array}$ \\
\hline
\end{tabular}

\section{H IST O R Y}

Protocol first published: Issue 2, 2007

Review first published: Issue 4, 2008

\begin{tabular}{lll}
\hline Date & Event & Description \\
\hline 8 May 2013 & New search has been performed & $\begin{array}{l}\text { Searches conducted. We included four new trials and performed } \\
\text { new analyses (Al-Ansari 2010; Miraglia Del Giudice 2012; Ipek } \\
2011 ; \text { Luo 2011). Our conclusions remain unchanged. }\end{array}$ \\
\hline 7 June 2010 & New search has been performed & $\begin{array}{l}\text { Searches conducted. We included three new trials and conduct- } \\
\text { ed new analyses (Anil 2010; Grewal 2009; Luo 2010). The conclu- } \\
\text { sions remain unchanged. }\end{array}$ \\
\hline 10 May 2010 & New search has been performed & $\begin{array}{l}\text { Searches conducted. We included three new trials and per- } \\
\text { formed new analyses (Anil 2010; Grewal 2009; Luo 2010). Our } \\
\text { conclusions remain unchanged. }\end{array}$ \\
\hline 13 May 2009 & Amended & No changes; republished to fix technical problem. \\
\hline 18 February 2008 & Amended & Converted to new review format. \\
\hline 13 November 2007 & New search has been performed & Searches conducted. \\
\hline
\end{tabular}

\section{CONTRIBUTIONS OF AUTHORS}

Linjie Zhang conceived the idea and wrote the draft protocol, primary review, and review updates.

Linjie Zhang and Raúl A Mendoza-Sassi were responsible for study selection, quality assessment, data collection, and data analysis.

Raúl A Mendoza-Sassi, Claire Wainwright, and Terry P Klassen provided input in the writing of the protocol and primary and updated reviews.

All authors approved the final version of this review update.

\section{DECLARATIONS OF INTEREST}

Linjie Zhang: None known.

Raúl A Mendoza-Sassi: None known.

Claire Wainwright: received travel grants from the North American Cystic Fibrosis Foundation and the European Cystic Fibrosis Society, travel and accommodation expenses from Novartis Pharmaceuticals and Vertex Pharmaceuticals, and travel and accommodation expenses from the University of Miami; has served as a consultant for/an advisory board member for Vertex Pharmaceuticals; has previously and is currently receiving grants or grants pending from the National Health and Medical Research Council (Australia), and has previously and currently is receiving funds from Vertex Pharmaceuticals for site costs associated with clinical trial participation and has previously received funds from Ablynx, and Novo Nordisk Phamaceuticals for site participation in clinical trials; and her institution has 
previously received payment for her providing lectures from Novartis Pharmaceuticals and Vertex Pharmaceuticals. None of the declared benefits were received in relation to this review or review topic or scope.

Terry P Klassen: None known.

\section{SOURCES OF SUPPORT}

\section{Internal sources}

- Faculty of Medicine, Universidade Federal do Rio Grande, Brazil.

\section{External sources}

- National Council for Scientific and Technological Development (CNPq), Brazil.

Fellowship of research productivity (PQ)

\section{DIFFERENCES BETWEEN PROTOCOL AND REVIEW}

Given the very limited number of studies that were identified initially (Zhang 2011), we added the comparison of nebulised hypertonic saline alone versus nebulised $0.9 \%$ saline since the first version of the review. We also clarified the population according to age and changed the title to specify infants. We performed post hoc subgroup analyses, post hoc meta-regression, and post hoc sensitivity analyses in the updated review. We also created and examined a funnel plot to explore possible small-study effects and publication bias. Cochrane Review methods have evolved over time, and these have been applied.

\section{N DEX TERMS}

\section{Medical Subject Headings (MeSH)}

Acute Disease; Airway Obstruction; Bronchiolitis, Viral [*therapy]; Bronchodilator Agents [administration \& dosage]; Length of Stay; Nebulizers and Vaporizers; Patient Readmission [statistics \& numerical data]; Randomized Controlled Trials as Topic; Saline Solution, Hypertonic [ ${ }^{\star}$ administration \& dosage]; Severity of Illness Index

\section{MeSH check words}

Humans; Infant 